\title{
Quaternary deposits and biostratigraphy in caves and grottoes located in the Southern Urals (Russia)
}

\author{
Guzel Danukalova ${ }^{\mathrm{a}, \mathrm{b}, *}$, Pavel Kosintsev ${ }^{\mathrm{c}}$, Anatoly Yakovlev ${ }^{\mathrm{a}}$, Tatyana Yakovleva ${ }^{\mathrm{d}}$, \\ Eugenija Osipova ${ }^{a}$, Ravil Kurmanov ${ }^{\mathrm{a}}$, Thijs van Kolfschoten ${ }^{\mathrm{e}, \mathrm{f}}$, Eugeny Izvarin ${ }^{\mathrm{c}}$ \\ a Institute of Geology of the Ufimian Federal Research Centre, Russian Academy of Sciences (RAS), Ufa, 16/2, K. Marx St, 450077, Russian Federation \\ ${ }^{\mathrm{b}}$ Kazan Federal University, 18, Kremlevskaya St., 420008, Kazan, Russian Federation \\ ${ }^{\mathrm{c}}$ Institute of Plant and Animal Ecology, Ural Branch, RAS, 202, 8th March St, 620008, Ekaterinburg, Russian Federation \\ ${ }^{\mathrm{d}}$ Bashkir State Pedagogical University n. a. M. Akmulla, 3A, October Revolution St., Ufa-centre, 450000, Russian Federation \\ ${ }^{\mathrm{e}}$ Faculty of Archaeology, Leiden University, Einsteinweg 2, 2333 CC, Leiden, the Netherlands \\ ${ }_{\mathrm{f}}^{\mathrm{f}}$ Institute of Cultural Heritage, Shandong University, 72 Binhai Highway, Qingdao, 266237, China
}

\section{A R T I C L E I N F O}

\section{Keywords:}

Pleistocene

Biostratigraphy

Caves

Southern Urals

\begin{abstract}
A B S T R A C T
Investigations of the unconsolidated Upper Pleistocene - Holocene cave deposits of the Southern Urals resulted in detailed biostratigraphical and palaeoenvironmental data. Landscapes of this area have a mosaic character. The forests have regional features developed at the transition of Eastern European broadleaved-dark-coniferous taiga and the Southern-Uralian light coniferous forests. The modern mountain mixed forests appeared during the end of the Holocene. The forest-steppes were widespread during Late Neopleistocene - Holocene. The forest vegetation existed during the warm periods (Tabulda, Middle-Late Holocene) and areas covered by forest were reduced during the cold intervals (Kudashevo, Early Holocene). However, refugia of broad-leaved flora existed in the territory of the Southern Urals even during coldest periods. The Late Pleistocene and Holocene mollusc species are Holarctic species that occur in forest-steppe, forest and intrazonal (river banks) ecological biotopes. The Late Pleistocene and Holocene amphibian associations found in caves are characterized by species that prefer forest biotopes. The reptile faunas contain species which inhabited open areas. The Pleistocene and Holocene fish fauna is a characteristic freshwater fauna occurring in a temperate zone: all species currently inhabit the European rivers. The Pleistocene and Holocene avifaunas include species that occur in the modern ornithological faunas of Northern Asia, Central and Northern Europe. The Late Pleistocene fauna was dominated by species that inhabited open and semi-open landscapes whereas, during the Holocene, species that preferred closed biotopes dominated the bird fauna. During the Late Pleistocene and Early Holocene disharmonious smallmammal faunas existed in the central and northern parts of the Southern Urals. These faunas included steppe and semi-desert species; lemmings are rare. In the southern part of the Southern Urals and in the Trans-Urals lemmings are absent. Starting from the Middle Holocene there is a gradual change of small-mammal communities. In the Southern Urals forest species replace the predominance of steppe species, and only in the Trans-Urals the steppe small mammal fauna preserved. The modern small-mammal faunal community appeared in the latitudinal part of the Belaya River valley at the end of the Late Holocene. There were relatively little changes in the Southern Urals large mammal fauna at the end of the Late Neopleistocene - beginning of Holocene. The large mammal fauna consisted of eurybiotic species and species that inhabit open landscapes. Species that prefer forest landscapes appeared at the end of the Early Holocene - beginning of the Middle Holocene. Modern large mammal species appeared during the second half of the Late Holocene.
\end{abstract}

\section{Introduction}

This paper presents the biostratigraphical data from the caves and grottoes located in the Southern Urals (approximately $52^{\circ}-56^{\circ} \mathrm{N}$ and $56^{\circ}-59^{\circ}$ E) (Fig. 1, Table 1). The area described in this paper was not well-known for a long time because it was difficult to reach the caves in

\footnotetext{
${ }^{*}$ Corresponding author. Institute of Geology of the Ufa Federal Research Centre Russian Academy of Sciences, 16/2, R. Marx St., 450077, Ufa, Russian Federation.

E-mail addresses: danukalova@ufaras.ru, guzel59@mail.ru (G. Danukalova), kpa@ipae.uran.ru (P. Kosintsev), a jakovlev@mail.ru (A. Yakovlev), tiy2@yandex.ru (T. Yakovleva), myrte@mail.ru (E. Osipova), ravil_kurmanov@mail.ru (R. Kurmanov), T.van.Kolfschoten@arch.leidenuniv.nl (T. van Kolfschoten), izvarin1982@mail.ru (E. Izvarin).
} 


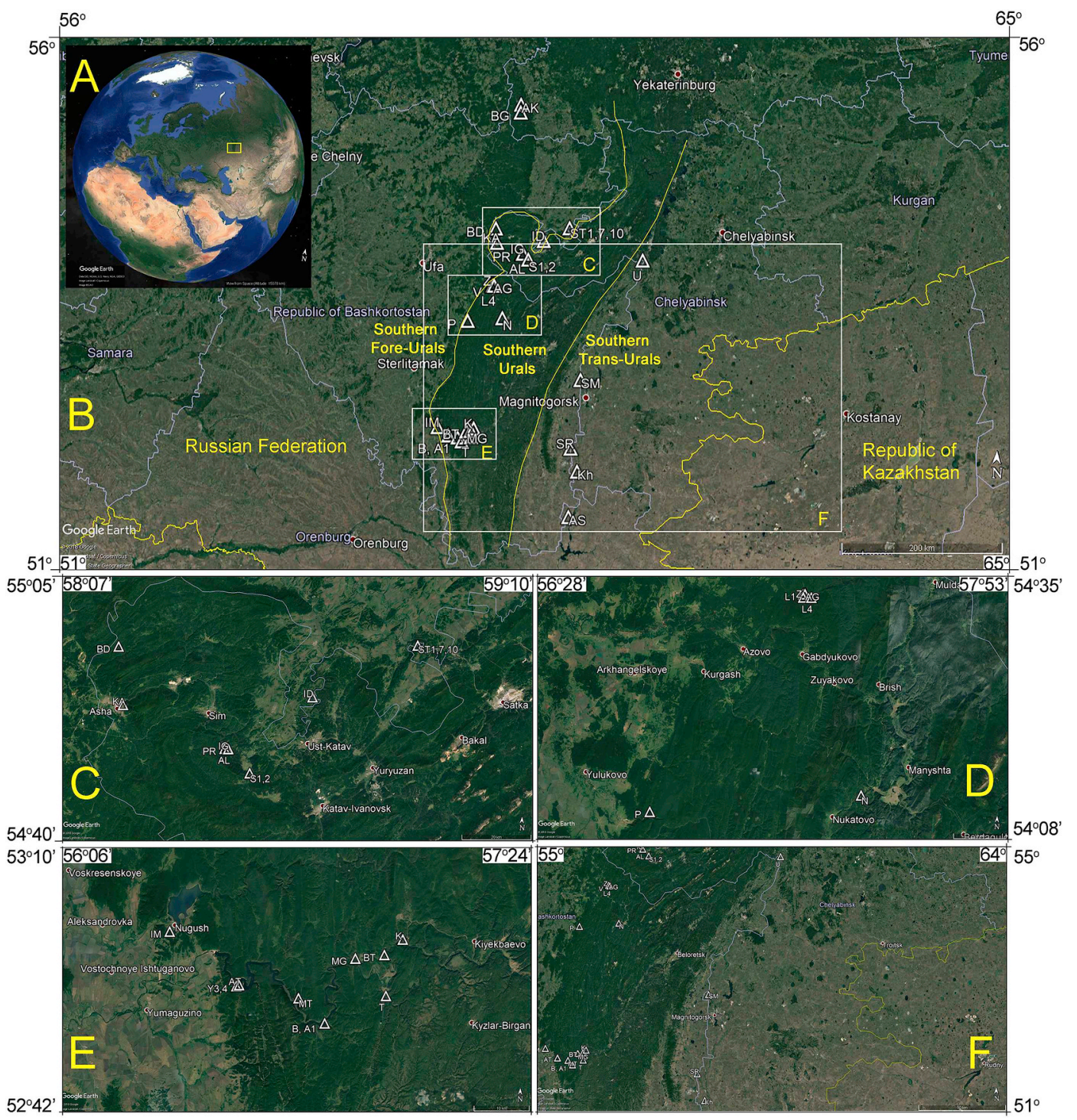

Fig. 1. Studied Southern-Uralian area with the locations of the caves.

Legend: A - general overview; B - locations of the caves discussed in this paper; C - the mountain part of the Southern Urals with the northern group of caves (Yuryuzan, Ai and Sim River valleys); D - the mountain part of the Southern Urals with central group of caves (Lemeza, Inzer, and Zilim River valleys); E - the mountain part of the Southern Urals with southern group of caves (latitudinal stretches of the Belaya and Nugush River valleys); F - the Southern Trans-Uralian area (Miass, Small and Big Kizil, Malaya Urtazymka River valleys). White triangles indicate the caves. For cave identifiers see Table 1. Maps are produced using Google Earth.

the mountainous part of the Urals. Biostratigraphical studies were often associated with archaeological excavations (Karacharovsky, 1951; Yakhemovich et al., 1970; Smirnov et al., 1990; Kuzmina and Abramson, 1997; Yakovlev et al., 2006; Saveliev et al., 2018, etc.) but also road construction works or the construction of water reservoirs offered sometimes the possibilities to a rescue survey of the unconsolidated deposits in the caves (Smirnov et al., 1990; Danukalova et al., 2011).

The Palaeozoic and Riphean sedimentary, metamorphic and magmatic rocks form different geological zones, from west to east: the Eastern part of the Eastern-European platform, the Fore-Uralian foredeep, the western and eastern slopes of the Southern Urals that corresponds to the eastern part of the Eastern-European Plan, the Southern Fore-Urals, the Southern Urals Mountains and the Trans-Urals.

There are several key-areas that yielded in the past biostratigraphical data; areas where the investigations will continue in the future. These areas are: the Southern Fore-Uralian area with the Ufimian Plateau; the mountainous part of the Southern Urals with a northern group of caves (Yuryuzan, Ai and Sim River valleys); the central group of caves (Lemeza, Inzer, and Zilim River valleys) and the southern group of caves (the latitudinal currents of the Belaya and Nugush River valleys); and the Southern Trans-Uralian area (Miass, Small and Big Kizil, Malaya Urtazymka River valleys) (Fig. 2). The elevation of the studied caves above modern thalwegs is shown in Fig. 2.

The caves constitute a natural database that is very informative and can help us to understand the past changes in the area. The main aim of our studies was to reconstruct the Late Pleistocene and Holocene palaeoenvironments based on the obtained biostratigraphical data. This paper presents the results of the biostratigraphical studies of the main localities i.e. the summarised stratigraphic description of the unconsolidated deposits, an overview of the fossil plants, molluscs and vertebrates and the radiocarbon age of the fossils incorporated in the unconsolidated deposits. 


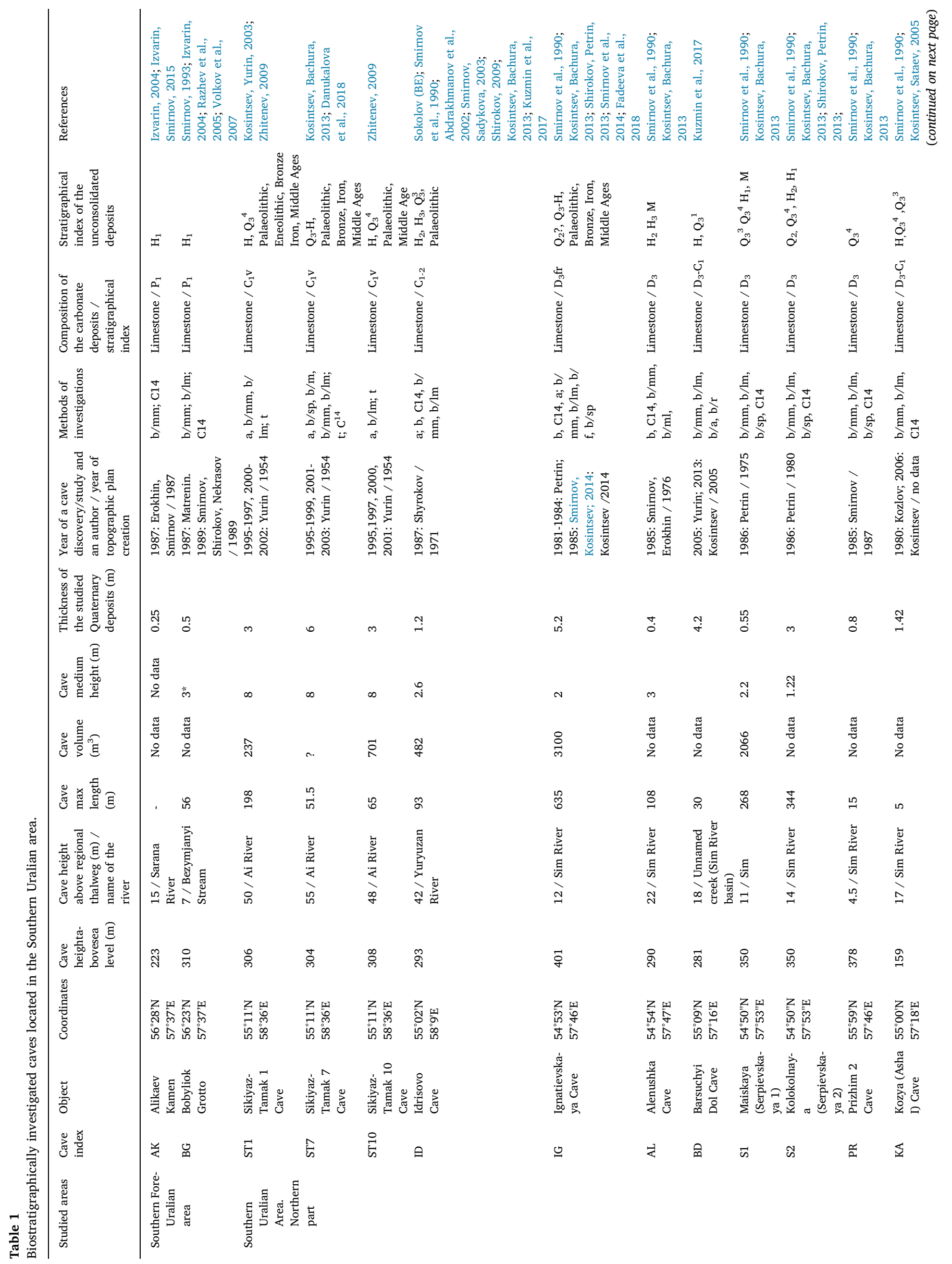




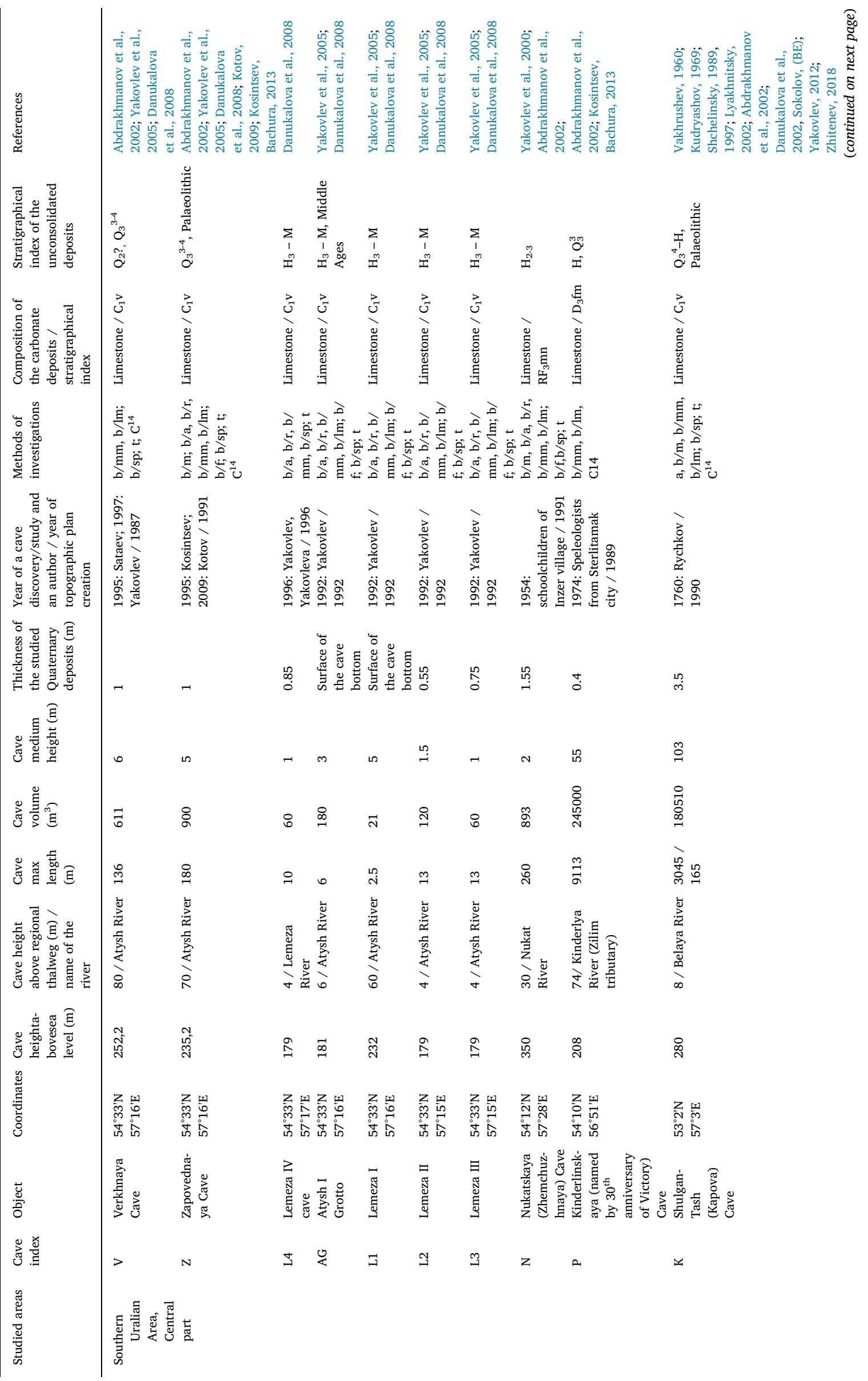




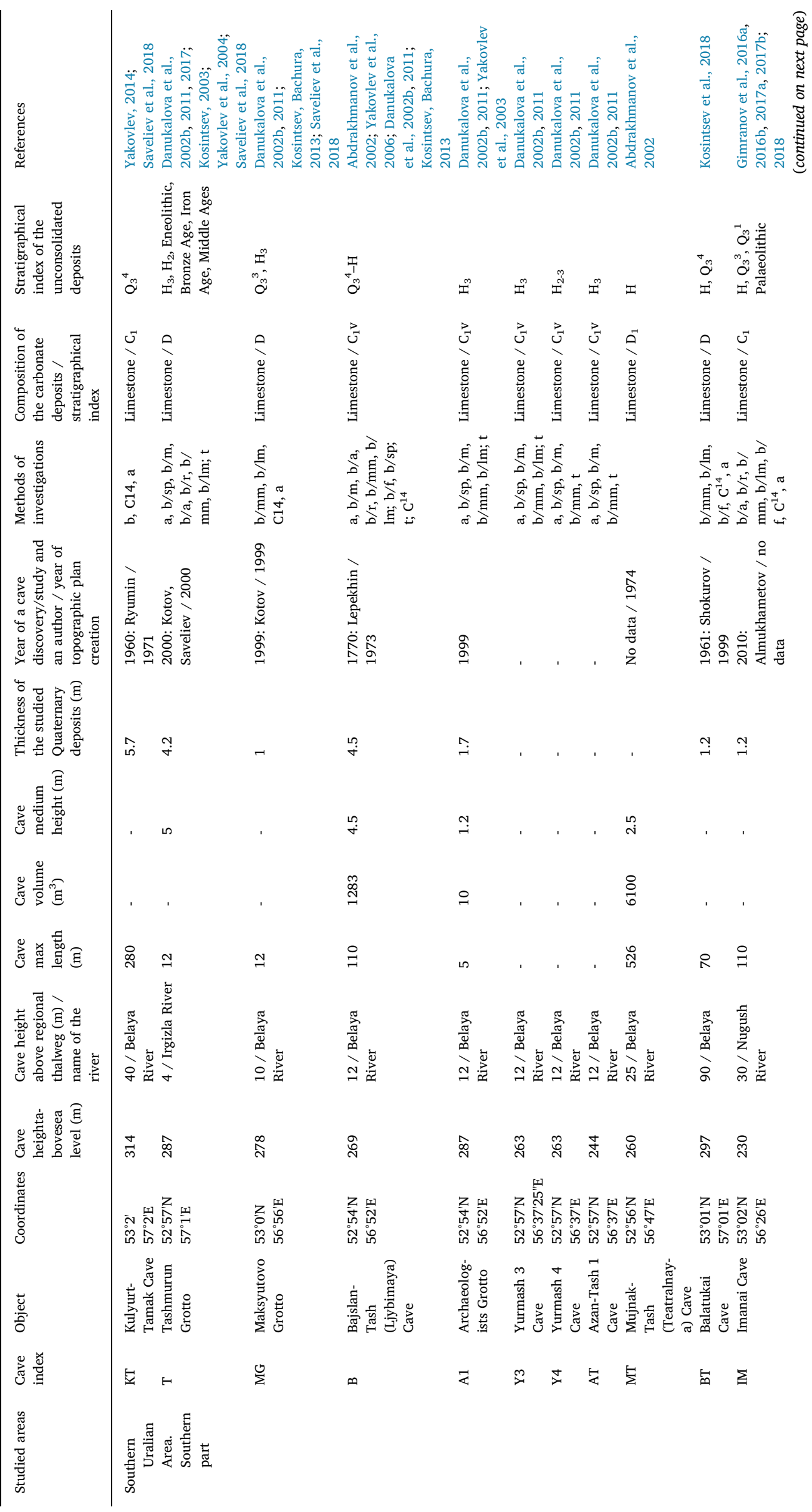




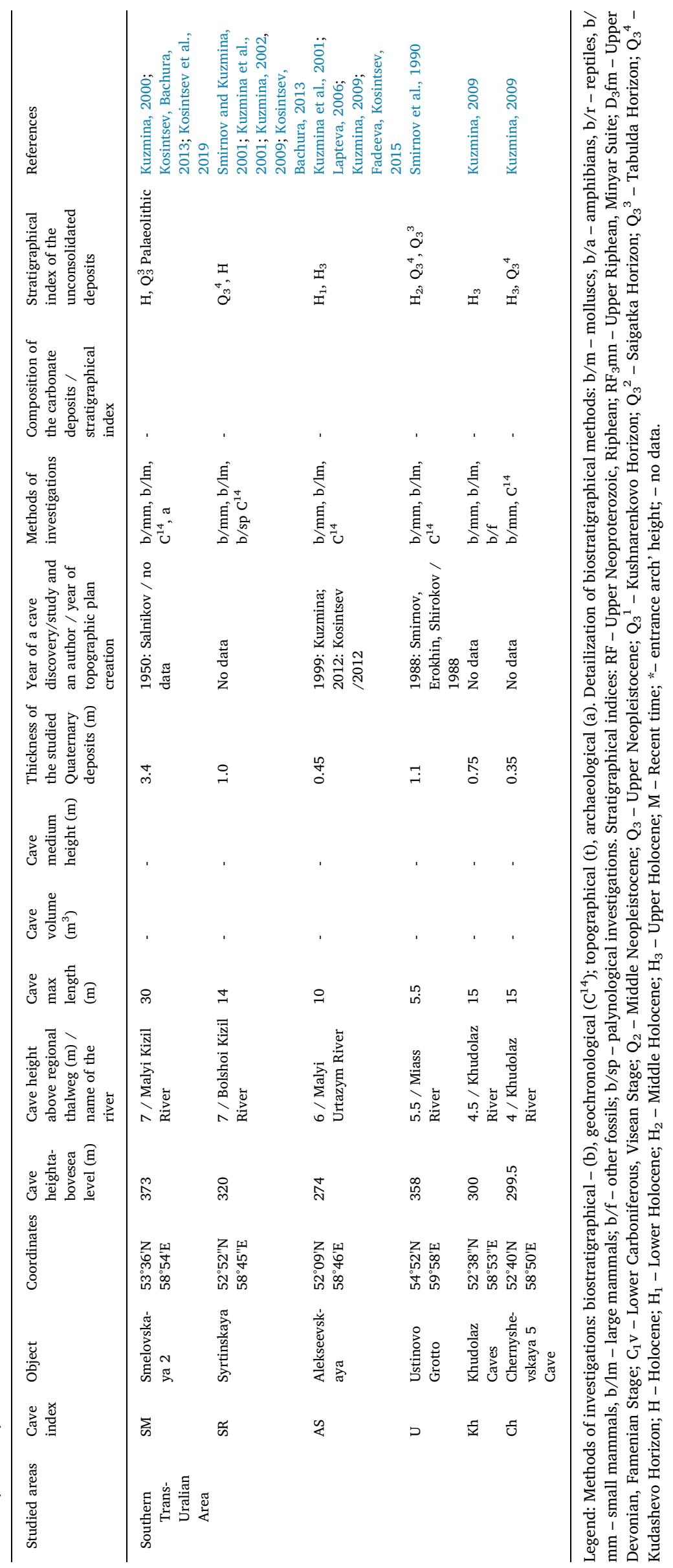




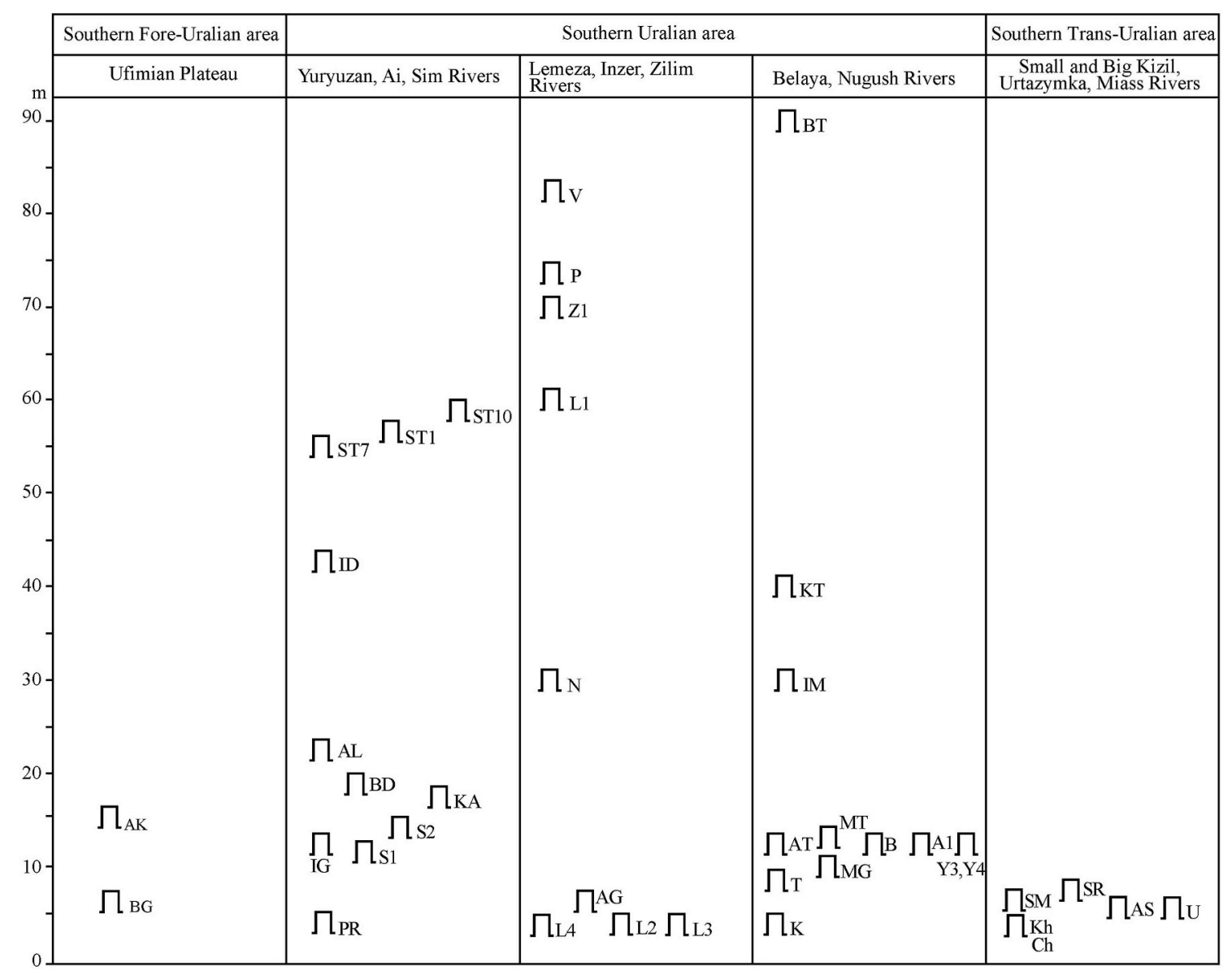

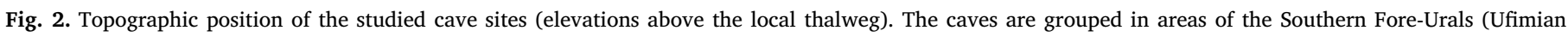

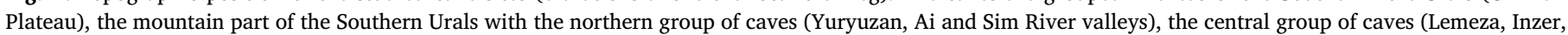

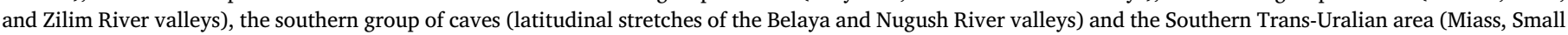
and Big Kizil, Malaya Urtazymka River valleys). For cave identifiers see Table 1.

\section{General geological background}

Based on tectonic features, the investigated area is subdivided, from west to east, into several structural zones - the Eastern margin of the Eastern-European Platform, the Fore-Uralian Foredeep, the Western and Eastern zones of the Central Uralian Uplift, and the Magnitogorsk zone (Puchkov, 2010).

The hills and upland areas of the Eastern margin of the EasternEuropean Platform are constituted of the sedimentary rock complex of mainly Permian deposits and Palaeogene-Neogene-Quaternary deposits that occur in the platform depressions. The Fore-Uralian Foredeep sedimentary complex is similar to the Platform Complex. The Upper Palaeozoic deposits form the Western part of the Southern Uralian folded area and the Riphean-Vendian complexes form the Central Uralian Uplifted area. The eastern part of the area consists of Palaeozoic volcanogenic and volcanogenic-sedimentary rocks.

The territory of the Southern Ural region is nowadays characterized by a moderately humid climate with a rainfall of 350-750 mm per year, providing moderate groundwater recharge. In addition, the area demonstrates a dissected relief, where Upper Proterozoic, Devonian, Carboniferous and Permian carbonate rocks, as well as Permian sulphate rocks are widespread. All these features are ideal for the development of the karst forms in about half of the studied territory ("Atlas, Respubliki Bashkortostan Atlas of Bashkortostan Republic," 2005). During the Quaternary, caves and grottoes were accumulating deposits that are the product of weathering processes. At the same time, caves were inhabited by animals and during Late Pleistocene - Holocene - by humans.

\section{Archaeological data}

The earliest archaeological finds in the caves of the Southern Urals area date back to the Middle Palaeolithic and correspond to the Mousterian epoch. Single artefacts of this age were found in the layer 13 of the Sikiyaz-Tamak 7 cave, which has a radiocarbon date of more than 57.300 years ago (OxA-10916) (Danukalova et al., 2018). A series of bifacial sharp points was found during the excavation of the Imanai cave; the shape of these points is similar to those from the third cultural layer of the Ilskaya Mousterian site in the Fore-Kuban area, Northern Caucasus (Gimranov et al., 2017a). Numerous bone remains of Ursus savini Andrews, 1922 and Pantera (Leo) ex gr. fossilis-spelaea Goldfuss, 1810 were found together with bifacial points (Gimranov et al., 2017a).

Late Palaeolithic archaeological finds from the caves are much more numerous. The archaeological sites in the Smelovskaya II cave (Bader, 1971) and in Idrisovo (Shirokov, 2009) are correlated with the early Late Palaeolithic (Table 2).

The archaeological layers of 23 caves are correlated with the late Late Palaeolithic (Table 2) (Bibikov, 1950a; Bader, 1971; Smirnov et al., 1990; Petrin, 1992; Yakovlev et al., 2006; Volkov et al., 2007; Saveliev et al., 2018; Kosintsev et al., 2018). The deposits in the Prizhim II cave (Smirnov et al., 1990) are correlated with the Last Glacial Maximum; eleven sites are correlated with the Last Glacial Transition and four sites are attributed to the Bolling-Allerød (Table 2). Ten archaeological levels in caves have a late Late Palaeolithic age with 


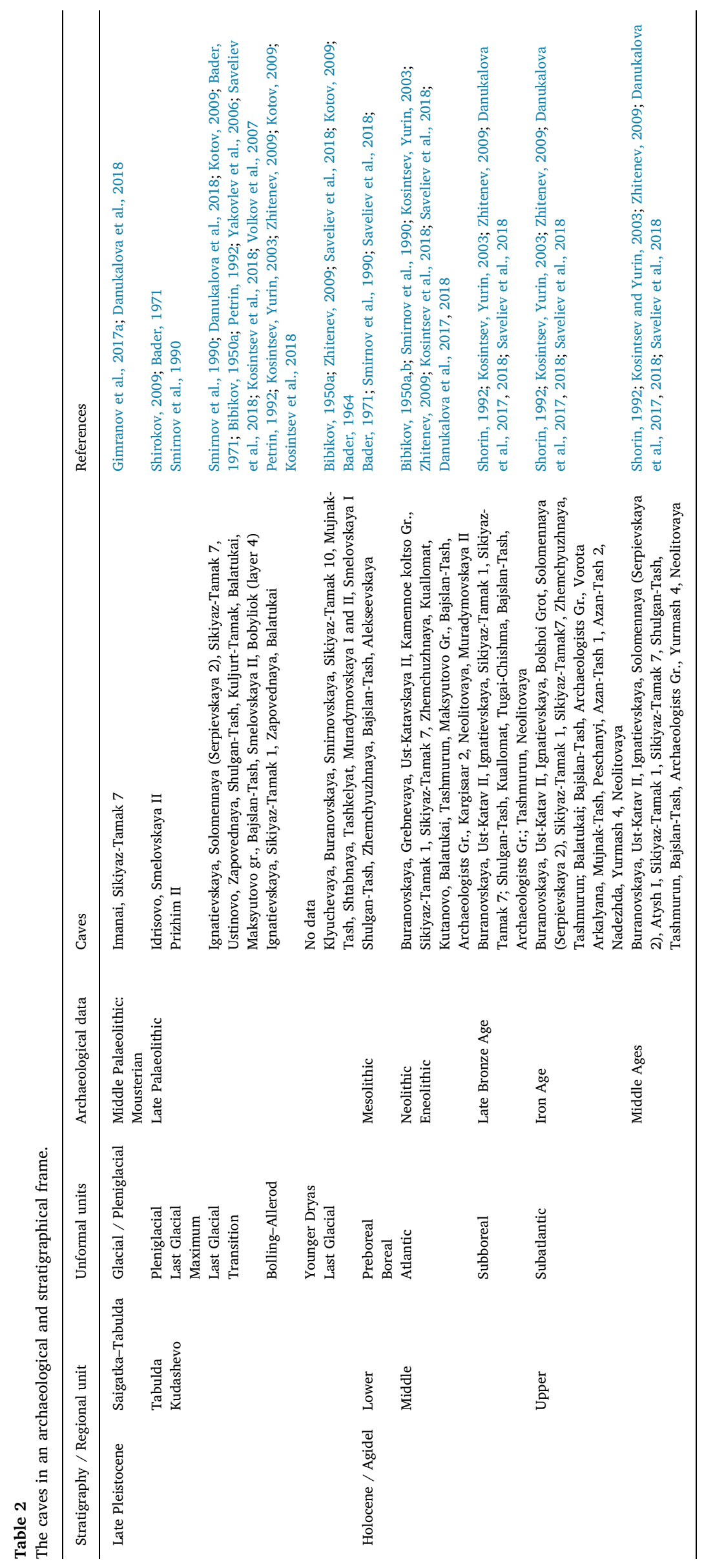




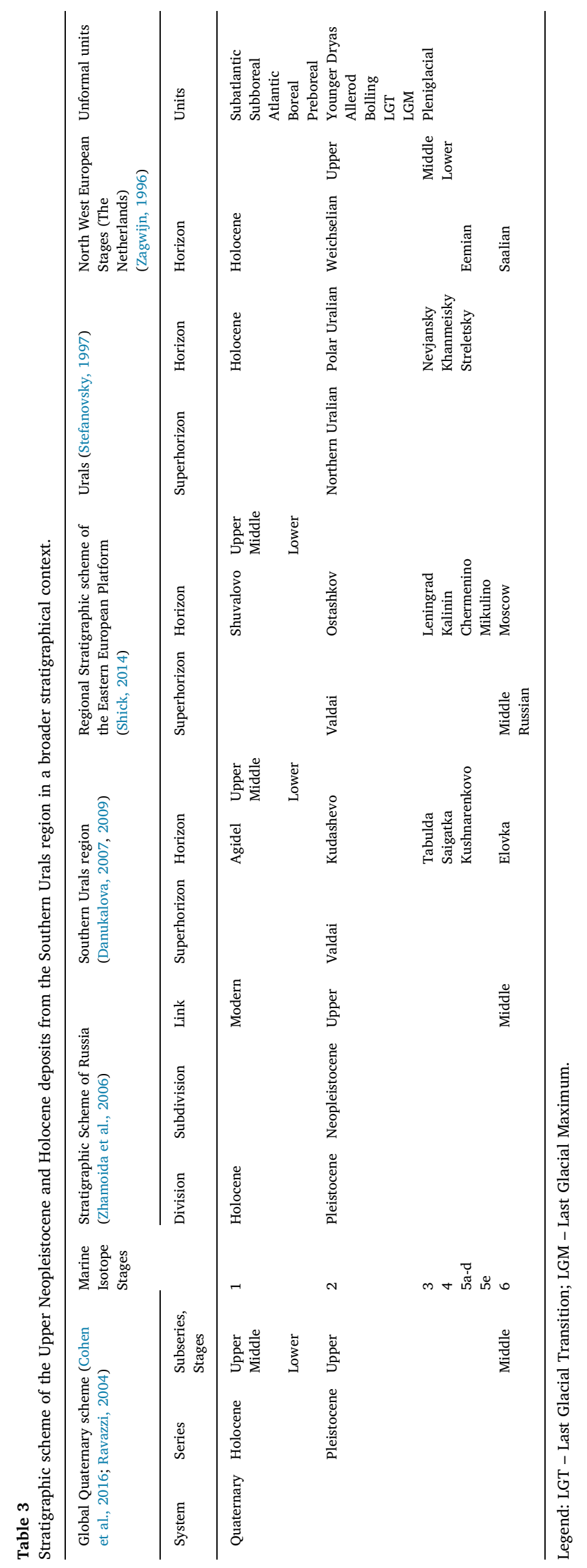


a wide range.

The Mesolithic, which corresponds to the Early Holocene (as well as to Preboreal and Boreal of the Blitt-Sernander scale), is represented by a small number of the artefacts found in six caves (Bader, 1971; Smirnov et al., 1990; Saveliev et al., 2018) (Table 2). In seventeen caves the Neolithic and the Eneolithic, which corresponds to the Middle Holocene, the Atlantic and the beginning of the Subboreal, is represented (Bibikov, 1950a,b; Smirnov et al., 1990; Kosintsev and Yurin, 2003; Zhitenev, 2009; Kosintsev et al., 2018; Saveliev et al., 2018; Danukalova et al., 2018) (Table 2). Burials of this time were found in four of these caves (Buranovskaya, Starichnyi Greben, Ust-Katav II, and the grotto at the Stone Ring) (Bibikov, 1950b).

Bronze Age artefacts (the end of the Middle Holocene; the middle and the end of the Subboreal time) were found in twelve caves (Shorin, 1992; Kosintsev and Yurin, 2003; Zhitenev, 2009; Daanukalova et al., 2018; Saveliev et al., 2018). The artefacts of the early Iron Age are most numerous in the caves of the Southern Urals; they were found in twenty caves (Shorin, 1992; Kosintsev and Yurin, 2003; Zhitenev, 2009; Danukalova et al., 2018; Saveliev et al., 2018). Artefacts of the Middle Ages were found in twelve caves (Shorin, 1992; Kosintsev and Yurin, 2003; Zhitenev, 2009; Danukalova et al., 2018; Saveliev et al., 2018).

Thus, artefacts from all main archaeological epochs, starting with the Mousterian, have been found in the caves of the Southern Urals. The caves were visited most often during the early Iron Age. The Bronze Age, the Early Iron Age and the Middle Ages are represented by several archaeological cultures. A number of caves - Shulgan-Tash, Ignatievskaya, Kolokolnaya (Serpievskaya 2), and Zhemchuzhnaya have Late Palaeolithic drawings on the walls of the interior halls of the caves (Sčelinskij and Širokov, 1999; Shirokov and Petrin, 2013; Saveliev et al., 2018). Some caves, such as Sikiaz-Tamak 1, were sanctuaries during the Iron Age (Kosintsev and Yurin, 2003).

\section{Material and methods}

\subsection{Stratigraphical and chronological data}

The article summarize biostratigraphical and geochronological data from important stratigraphical levels exposed in 35 cave sites, studied by the authors and our colleagues of the Institute of Plant and Animal Ecology of the Ural Branch RAS (Ekaterinburg) (Tables 1 and 4; Fig. 1).

The local stratigraphical units are correlated with the recent stratigraphical scheme of the Neopleistocene and Holocene deposits in the Southern Fore-Urals area; a scheme that is based on biostratigraphic data from key sites in the region, combined with archaeological, radiocarbon dates and palaeofaunal data (Danukalova, 2010). The upper part of the Neopleistocene (= Upper Pleistocene of the International Stratigraphic Chart (Cohen and Gibbard, 2016)) is subdivided into four horizons with local names: Kushnarenkovo (corresponds to MIS 5), Saigatka (MIS 4), Tabulda (MIS 3), Kudashevo (MIS 2) and Agidel Horizon corresponding to the Holocene (MIS 1) (Table 3). The Holocene is subdivided into the Lower (10-8 ka BP), Middle (8-2,5 ka BP) and Upper Holocene (2,5 ka - recent), a subdivision that is traditionally used in Russia during geological survey work (Shick, 2014). The actual data presented and discussed in this paper was collected during the past ca. 50 years by different authors; authors that also used the traditional (Russian) stratigraphical subdivision of the Holocene. We are aware of the fact that the applied subdivision differs from the recently, by the International Union of Geological Sciences ratified, formal subdivision of the Holocene Epoch into three distinct subsections, Greenlandian (11,700 years ago to 8326 years ago), Northgrippian (8326 years ago to 4200 years ago) and Meghalayan (4200 years ago to the present) (Walker et al., 2009). The 4.2 ky boundary is, however, not well reflected in our region, in contrast to the $2.5 \mathrm{ky}$ boundary, which is rather clear in the palaeobotanical record; a boundary that also correlates with the late Bronze/early Iron Age transition (Khotinsky, 1977). Therefore, for practicle reasons, we decided to use the traditional (Russian) stratigraphical subdivision of the Holocene.

All radiocarbone dates $\left(\mathrm{C}^{14}\right)$ were obtained, following the standard methodology, in different geochronological laboratories (see Table 4). Part of the large mammal faunas with an age beyond the radiocarbon dating method (i.e. an age beyond ca. $50 \mathrm{ka}$ ) are stratigraphically dated on the base of the species composition of the large and small-mammalian assemblages (Smirnov, 1993; Fadeeva et al., 2018; Kosintsev et al., 2013; subchapter 6.7 this paper) and/or on the base of the enamel differentiation coefficient (SDQ) of the Arvicola terrestris (Linnaeus, 1758) molars.

\subsection{Palynological analysis}

Quaternary deposits of 15 caves were studied palynologicaly: Zapovednaya Cave (Alimbekova et al., 1998), Lemeza II, III, IV (Alimbekova et al., 2000; Danukalova et al., 2008), Nukatskaya (Yakovlev et al., 2000), Verkhnyaya (Eremeev, 2003), Bajslan-Tash (Yakovlev et al., 2006), Shulgan-Tash (Eremeev and Kurmanov, 2011), Azan-Tash I, Yurmash 3, 4, Muinak-Tash (Danukalova et al., 2011), Archaeologists and Tashmurun grottoes (Danukalova et al., 2017b) and Sikiyaz-Tamak 7 (Danukalova et al., 2018). Additionally we used in our analyses published palynological data from five caves (Serpievskaya 1 and 2, Ignatievskaya 2, Prizhim 2 and Syrtinskaya) published by Panova (in Smirnov et al., 1990) and Lapteva (2006). The palynological analytic process was done following the standard methods described by Grichuk and Zaklinskaya (1948) with some additions. The basis of the calculation of the percentages for various taxa is the sum of all the grains of pollen and spores (100\%) found in a sample. The identification of the pollen and spore species is based on, Kupriyanova and Aleshina (1972, 1978), Bobrov et al. (1983), and the recent spore and pollen collection of the Institute of Geology UFRC RAS (Ufa) has been consulted.

\subsection{Palaeofaunal analysis}

Molluscs. In total 2111 mollusc shells and identifiable fragments from the unconsolidated deposits of ten caves (Nukatskaya, BajslanTash, Yurmash 4 and 3, Azan-Tash, Sikiyaz-Tamak 7, Zapovednaya caves; Maksyutovo, Archaeologists, and Tashmurun grottoes) were studied by the authors. Traditional methods of dispersal of sediments in water, using sieves with mesh sizes of 0.5 and $1.0 \mathrm{~mm}$, were used to recover the molluscan and small-mammal remains (Zhadin, 1952; Steklov, 1966; Il'ina, 1966; Kaplin, 1987). Zhadin (1952), Likharev and Rammelmeier (1952), Shileyko (1978, 1984), Shileyko and Likharev (1986), Kerney and Cameron (1999), Nederlandse Fauna 2 (1998), Glöer (2002) are used to identify the species. For the malacological taxonomic nomenclature, we used the publication of Falkner et al., 2002).

Vertebrates. In total 7256 amphibian bone remains from eight localities (Bajslan-Tash, Lemeza II, III, IV, and Zapovednaya caves; Maksyutovo, Archaeologists, and Tashmurun grottoes) were identified; 1888 bone remains of reptiles from 9 caves (Bajslan-Tash, Lemeza II, III, IV, Yurmash 4, and Zapovednaya caves; Maksyutovo, Archaeologists, and Tashmurun grottoes) were identified and 27961 small-mammal remains from 13 caves (Bajslan-Tash, Alikaev Kamen', Lemeza II, III, IV, Nukatskaya, Yurmash 4, Azan-Tash 1, and Yurmash 3 caves; Bobyliok, Maksyutovo, Archaeologists, and Tashmurun grottoes) were described. There are fish and birds remains in the caves: fish bones were collected at eight caves (Ignatievskaya, Maiskaya (Serpievskaya 1), SikiyazTamak 7, Imanai, Prizhim 2, Kolokolnaya (Serpievskaya 2), Zapovednaya, and Nukatskaya caves), bird remains are known from eight caves (Balatukai, Lemeza II, Verkhnaya, Zapovednaya, Nukatskaya, Sikiyaz-Tamak 6 and 10 caves; Atysh I Grotto). In total 63350 large-mammal remains from 25 localities were identified.

Amphibians, reptiles and small-mammal species were identified 


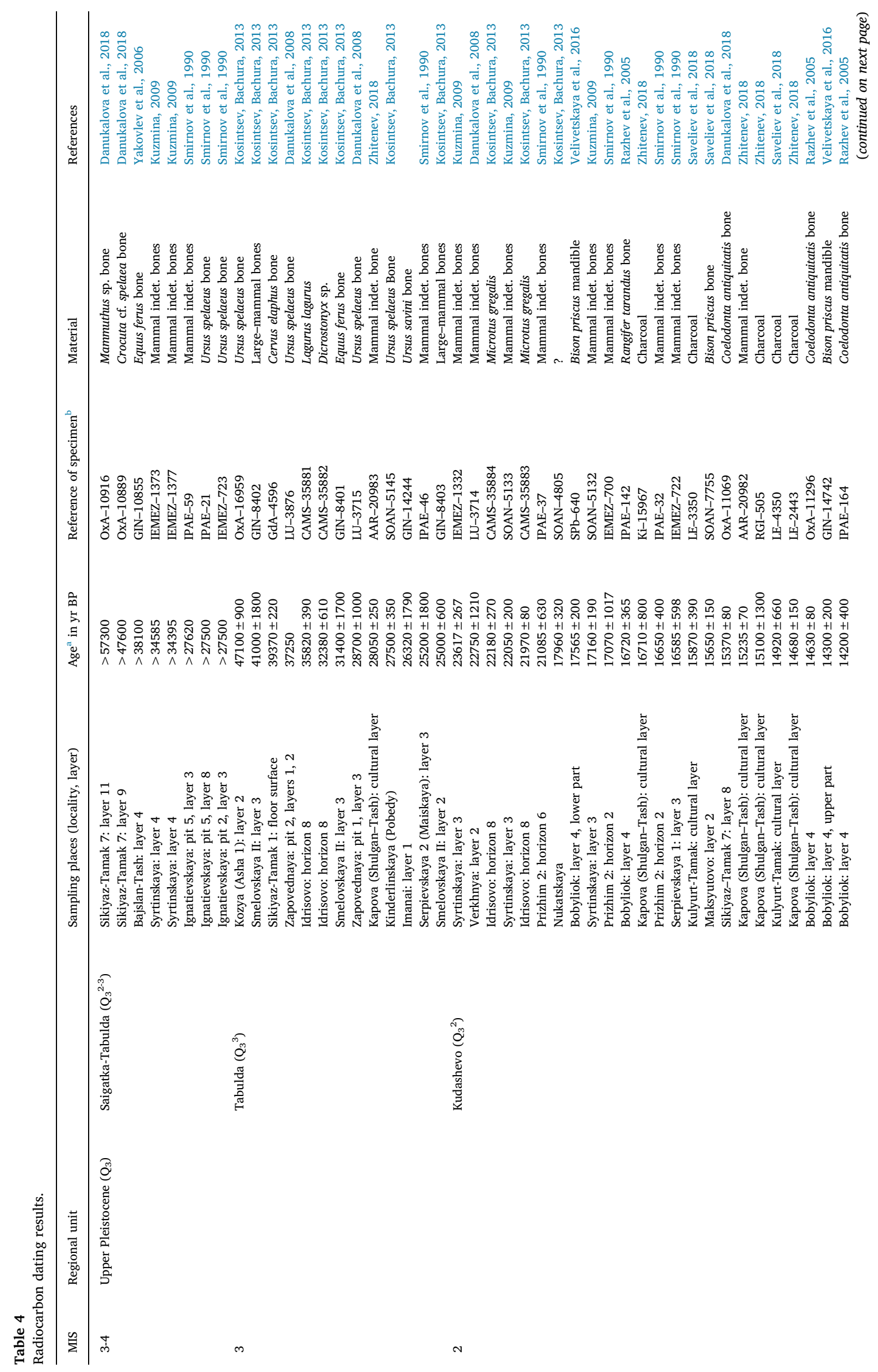




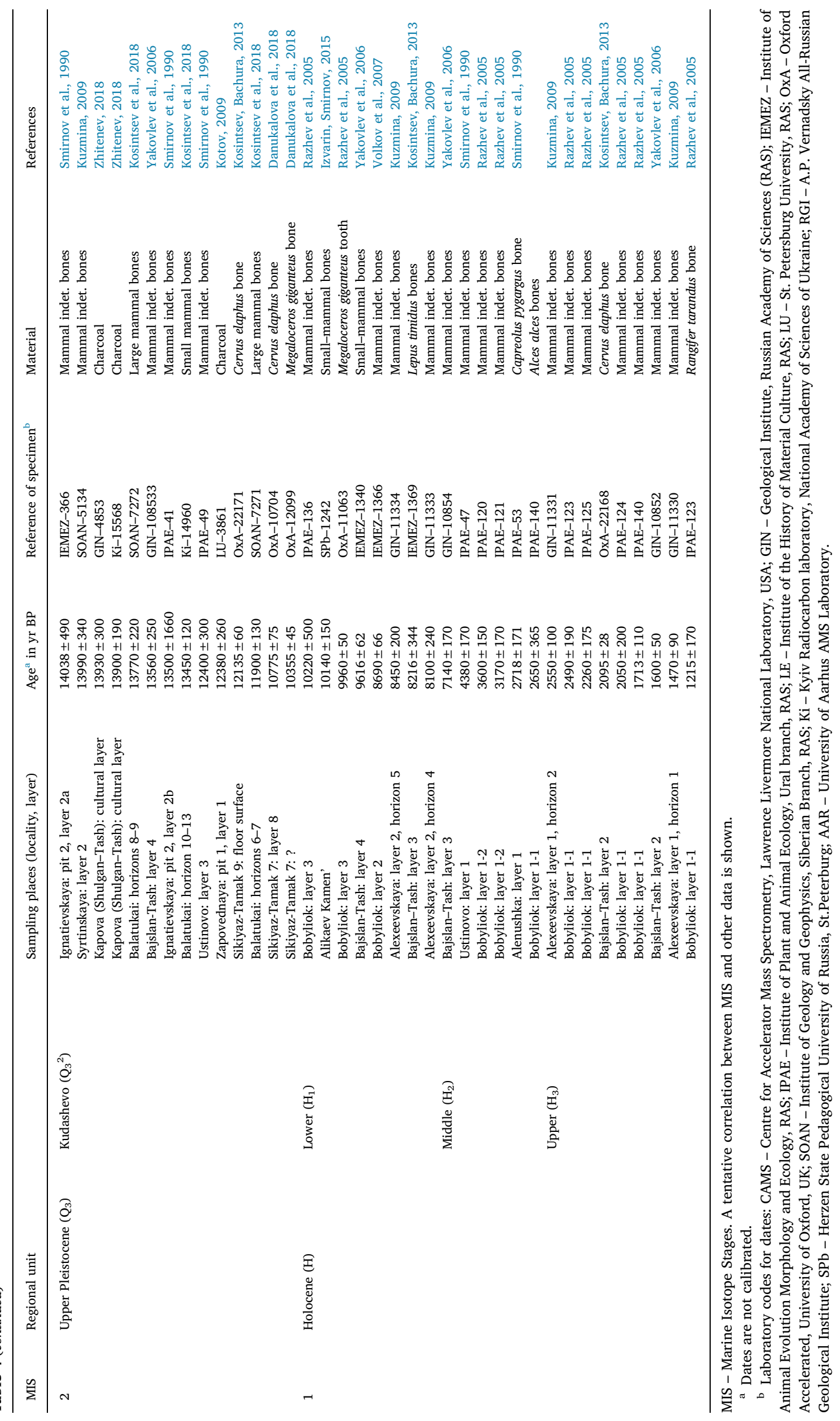




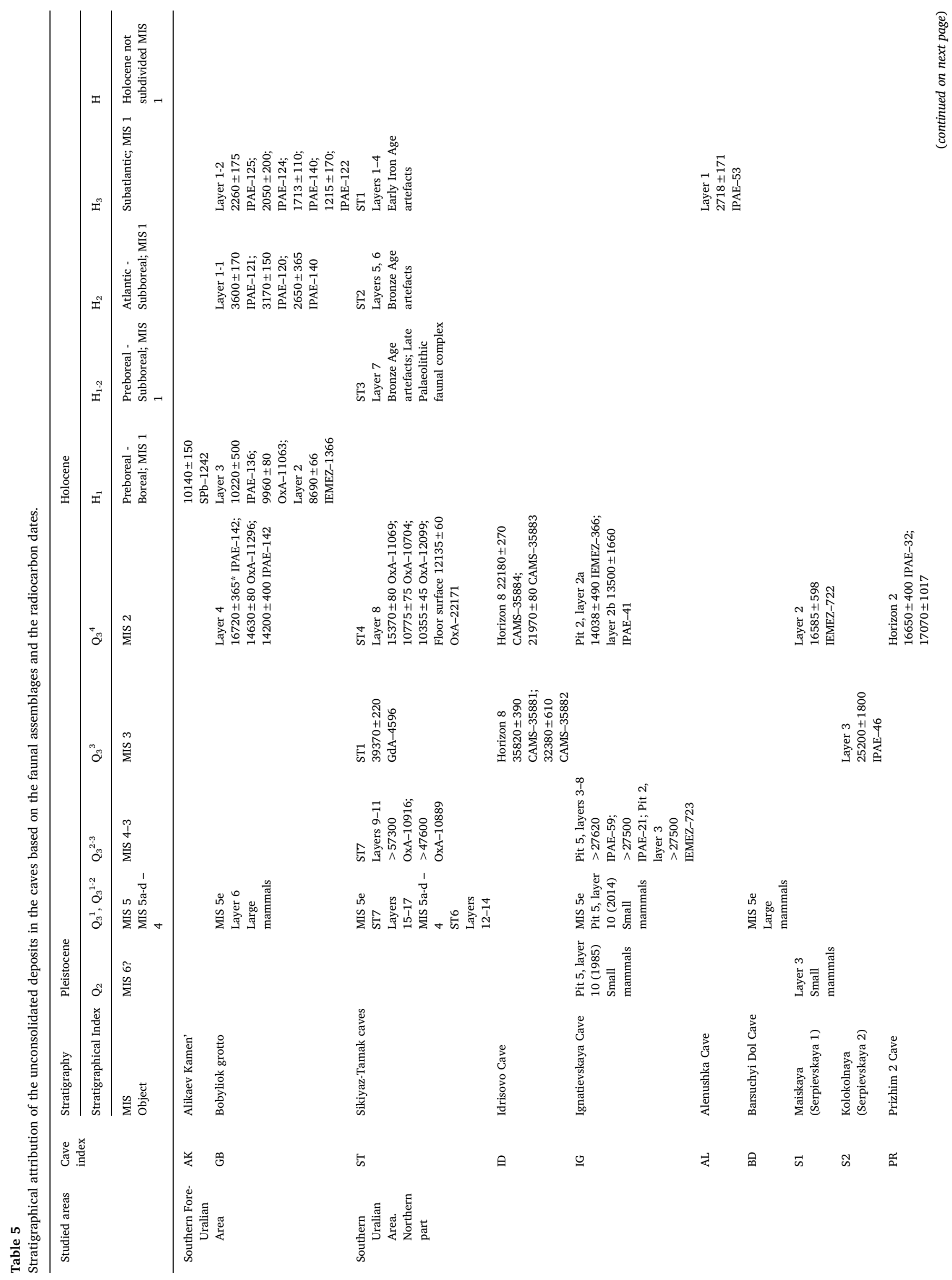




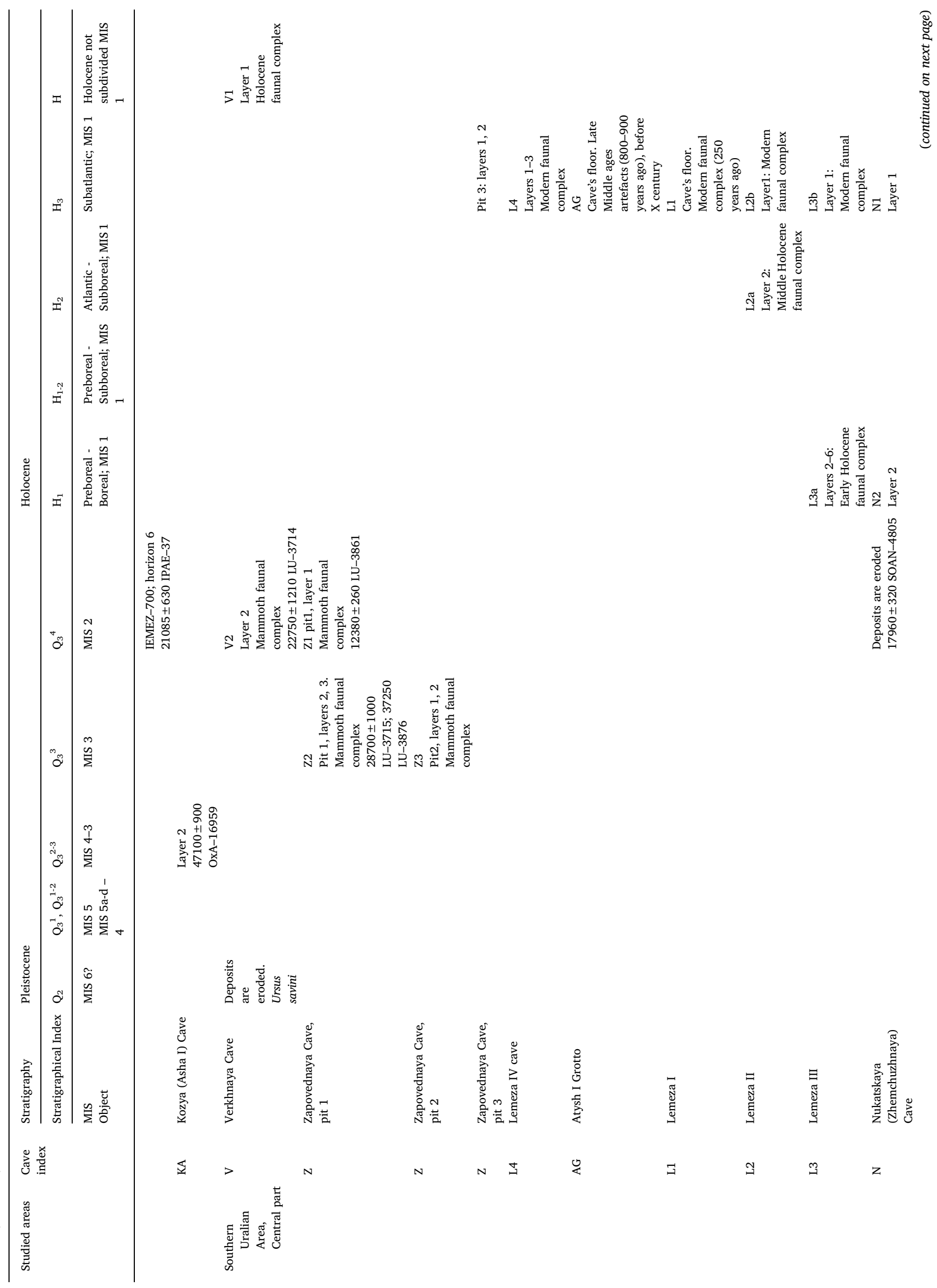




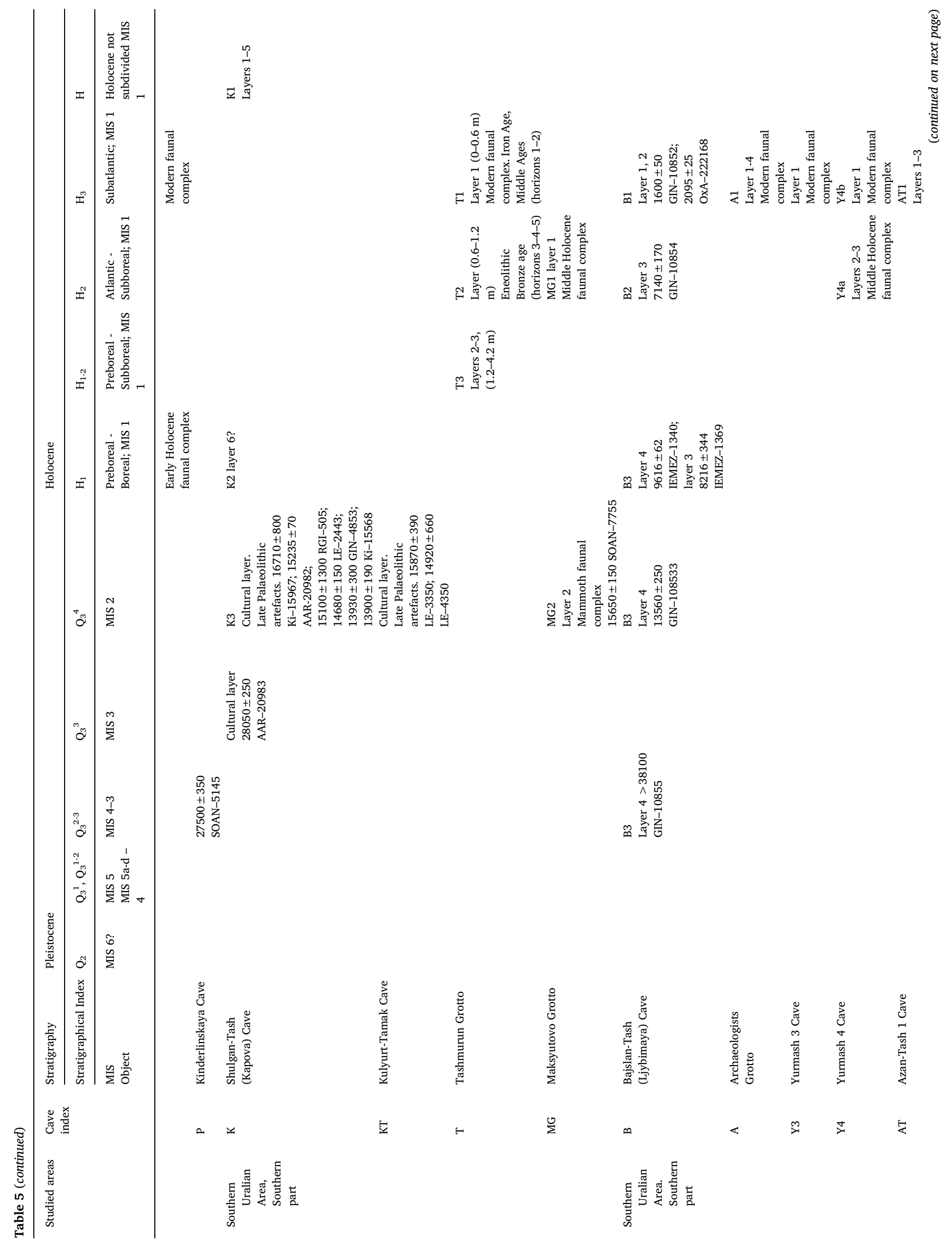




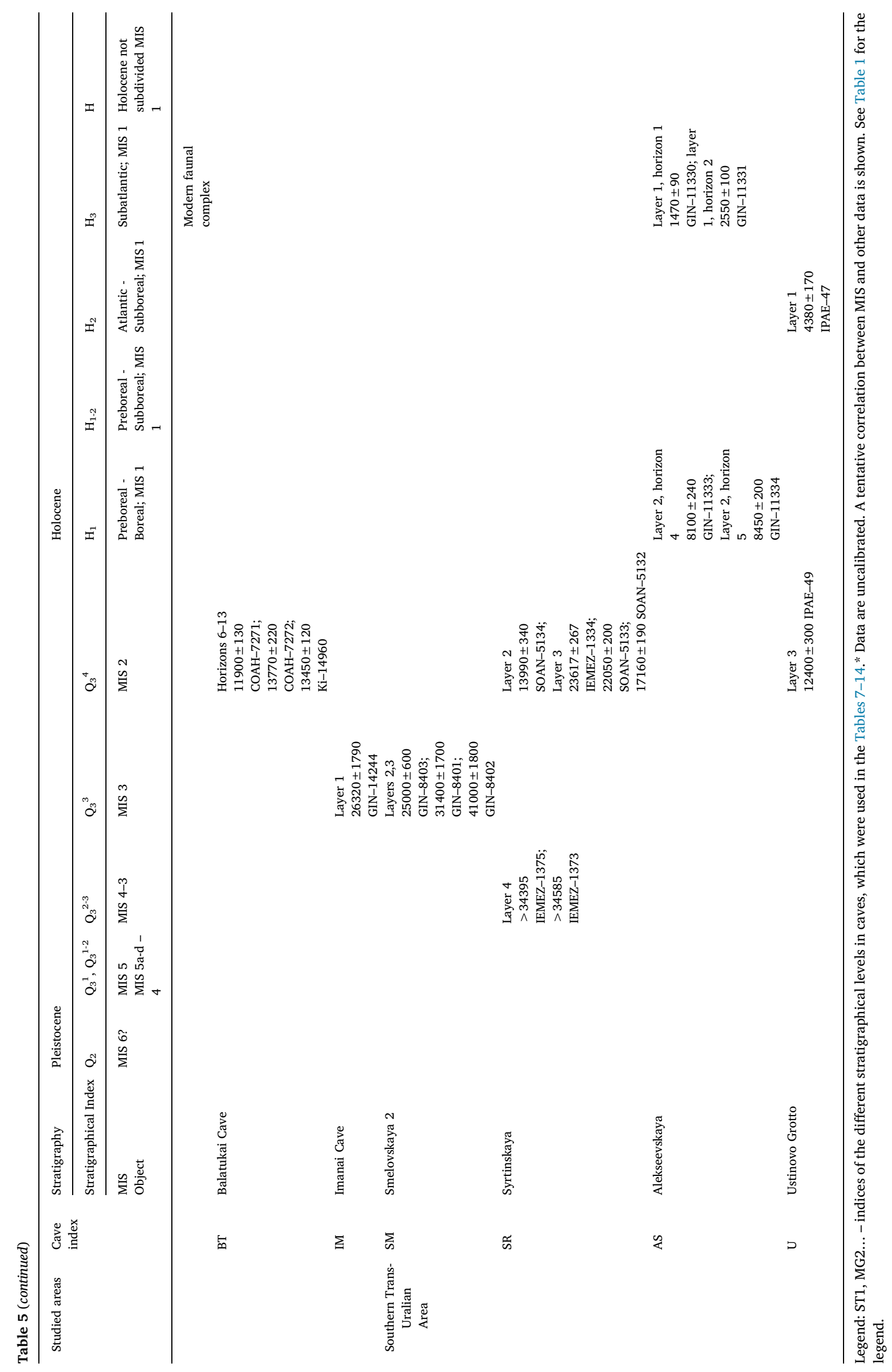


using Ratnikov (2002), Agadjanian (2009) and Borodin (2009). The Late Pleistocene and Holocene amphibians and reptiles were studied by Yakovleva (in Danukalova et al., 2008) (valley of the Lemeza River) and (in Danukalova et al., 2011) (valley of the Belaya River); small mammal faunas from the cave sites of the Southern Urals in the northern part of the region (Ufimian Plateau) were studied by Izvarin (2004, 2015, Izvarin, 2017 and Smirnov (1993); fossil remains from the central part of the region they were studied by Smirnov (in Smirnov et al., 1990) (the valley of the Sim River and the Yuryuzan River) and by Yakovlev (in Danukalova et al., 2008) (valley of the Lemeza River). The southern part of the Southern Urals the cave sites with small mammals were studied by Yakovlev (in Danukalova et al., 2011) (valley of the Belaya River). Small mammals from caves in the Southern Trans-Urals were studied by Smirnov (in Smirnov et al., 1990) and Kuzmina, 2003a, 2003b; 2009). Large mammals remains were studied by Kosintsev, additional data of other authors were cited in the text: Kapova Cave (Kuzmina, Abramson, 1997), Smelovskaya 2 Cave (Kuzmina, 2000), Syrtinskaya Cave (Kuzmina, 2003), Atysh I Grotto (Sataev, 2005), Kulyurt-Tamak Cave (Saveliev et al., 2018). Fish and bird remains were summarised by the authors with references listed in the text and the tables.

The shells of molluscs, amphibians, reptiles and partly small mammals were photographed at the Institute of Geology UFRC RAS (Ufa) using a stereomicroscope Motic SMZ-171 TLED with a camera Moticam10x and/or with a camera Sony ILCE-6000 and a lens Sony SEL35F18.

\section{Results}

\subsection{Stratigraphy and chronology}

Unconsolidated cave deposits of eluvial-slope genesis cover the bottom surfaces of the caves and grottoes. They consist of (mainly) light-brown or reddish-brown loam and sandy loam and sometimes sand and clay occur in the lower parts of the deposits. The deposits contain numerous small and big-size limestone debris, as well as floral and faunal remains. Artefacts of different archaeological cultures occur in some levels. The thickness of these deposits differs and depends on the location of the deposit's section in the outer/inner parts of the caves and on the height above thalweg (Table 1). A summarised description of the unconsolidated deposits with their (possible) attribution to the MIS stages and the Western-European stratigraphical units is given below (Tables 3 and 5 ).

Middle Pleistocene (Upper Saalian? MIS 6?). Deposits of this interval are eroded and only a bone assigned to Ursus cf. deningeri Reichenau, 1904 discovered in Verkhnya Cave indicate a late Middle Pleistocene age. Deposits of the same age were also discovered inside the cracks in the rocky bottom of the Ignatievskaya (pit V, layer 10, excavation of 1985) and Maiskaya (Serpievskaya 1) (layer 3) Caves.

Kushnarenkovo? Horizon (lower part) (Eemian? MIS 5e?). White loamy sand and yellow clay with rare pebbles (thickness is $0.5 \mathrm{~m}$ ) were encountered in the lowermost part of a pit in the Sikiyaz-Tamak 7 Cave. Cracks in the rocky floor of the Ignatievskaya Cave (pit V, layer 10, excavation of 2014) at the depth of 3.1-5.2 m were filled with lightbrown silty clay and small fragments of limestone.

The Kushnarenkovo-Saigatka Horizons (Lower Weichselian, MIS $5 a-d-4$ ) consist of reddish-brown and yellowish-brown clay (average thickness is $1.75 \mathrm{~m}$ ) with pebbles and sharp-edge limestone fragments.

The Tabulda Horizon (Middle Weichselian, MIS 3) is represented by yellowish-brown loam with limestone debris (average thickness is $3.2 \mathrm{~m}$ ) and Upper Palaeolithic large mammal bones (Sikiyaz-Tamak 1, Idrisovo, Serpievskaya 2, Zapovednaya, Ignatievskaya, Imanai, Nukatskaya, Shulgan-Tash, and Smelovskaya 2 Caves).

The Kudashevo Horizon (Upper Weichselian, MIS 2) is represented by yellowish-brown loam with limestone debris (average thickness is $0.8 \mathrm{~m}$ ) and Upper Palaeolithic large mammal bones and artefacts (Sikiyaz-Tamak 4, Idrisovo, Ignatievskaya, Serpievskaya 1, Prizhim 2,
Verkhnaya, Zapovednaya, Nukatskaya, Shulgan-Tash, Kulyurt-Tamak, Bajslan-Tash, Balatukai, Syrtinskaya Caves and Babyliok (layer 4), Maksyutovo and Ustinovo Grottoes).

The Agidel horizon (Holocene, MIS 1) is represented by loamy facies with limestone debris that can be subdivided into Lower, Middle and Upper Subhorizons using geochronological data and based on the composition of the mammalian faunas. The Lower Subhorizons deposits consist of brown loam with limestone debris and blocks. The thickness of these deposits is around $0.8 \mathrm{~m}$. Deposits of this age were described in the localities of Alikaev Kamen', Lemeza III, Nukatskaya, Shulgan-Tash, Bajslan-Tash, Alekseevskaya caves, and Bobyliok Grotto (layers 2 and 3). The Middle subhorizon deposits consist of grayish-brown and brown sandy light loam with limestone debris and blocks. Ash layers and Bronze Age artefacts are known from those deposits. The average thickness is $0.85 \mathrm{~m}$. Deposits of this age were described in the localities Sikiyaz-Tamak 7, Lemeza II, Bajslan-Tash, Yurmash 4 caves, and Tashmurun, Maksyutovo, Ustinovo Grottoes. The Upper subhorizon is characterized by brownish-gray loam (average thickness is $1 \mathrm{~m}$ ) with limestone debris with ashes and artefacts from the Early Iron age to recent. Deposits of this age are represented in numerous caves distributed all over the studied area.

\subsection{Palynology}

Analysis of the samples from sediments of 20 caves made it possible to characterize the Late Pleistocene (Tabulda and Kudshevo horizons) and the Holocene flora. The pollen spectra reflect both local (plant communities of rocks, represented in many spectra by a high proportion of Polypodiaceae), and regional vegetation features (forest, foreststeppe, periglacial steppe). The dynamics of landscape changes in the South Urals during the Late Neopleistocene - Holocene are shown in Table 6 and Fig. 3.

\subsection{Malacology}

Mollusc shells were found in deposits correlated with the second half of the Late Pleistocene (Tabulda and Kudashevo Horizons) and the Holocene (Table 7, Fig. 4).

In total 94 terrestrial mollusc shells representing 5 different taxa were collected from the Tabulda Horizon deposits (Zapovednaya cave, pit 1, layer 3). Only 50 shells and their fragments belonging to ten terrestrial species (eight genera) and five freshwater species (4 genera) were collected from the deposits of Kudashevo Horizon of the BajslanTash cave (see Table 7).

All the Holocene stratigraphical units yielded mollusc shells.

In total 427 shells and their fragments, representing 10 terrestrial gastropod species ( 9 genera) and 4 freshwater gastropod and bivalve species, were found in the Lower Holocene deposits of the Nukatskaya cave and the Tashmurun Grotto. The Middle Holocene deposits are known from the Bajslan-Tash and Yurmash 4 caves and the Maksyutovo Grotto. Nine terrestrial species (8 genera) and 4 freshwater species were identifies among the 32 extracted shells and their fragments.

The Upper Holocene deposits were recorded in several caves - the Archaeologists and Tashmurun Grotto, Bajslan-Tash, Azan-Tash 1, Yurmash 3 and 4, Nukatskaya and Sikiyaz-Tamak 7 caves. In total 674 mollusc shells and their fragments were discovered representing 13 terrestrial and 10 freshwater species.

The malacological study resulted in the identification of terrestrial (15 species) and freshwater (12 species) molluscs which belong to two classes, Gastropoda and Bivalvia. The malacological assemblages consist of species that are widely distributed in the study area. Terrestrial molluscs are inhabitants of forest biotopes, with dense grass cover and leaf litter under shrubs and trees. They could inhabit the rocky wellwarmed slopes under the stones. The presence of freshwater molluscs in the collections is due to the presence of nearby water bodies from where the shells were transported by animals. Freshwater molluscs lived in 


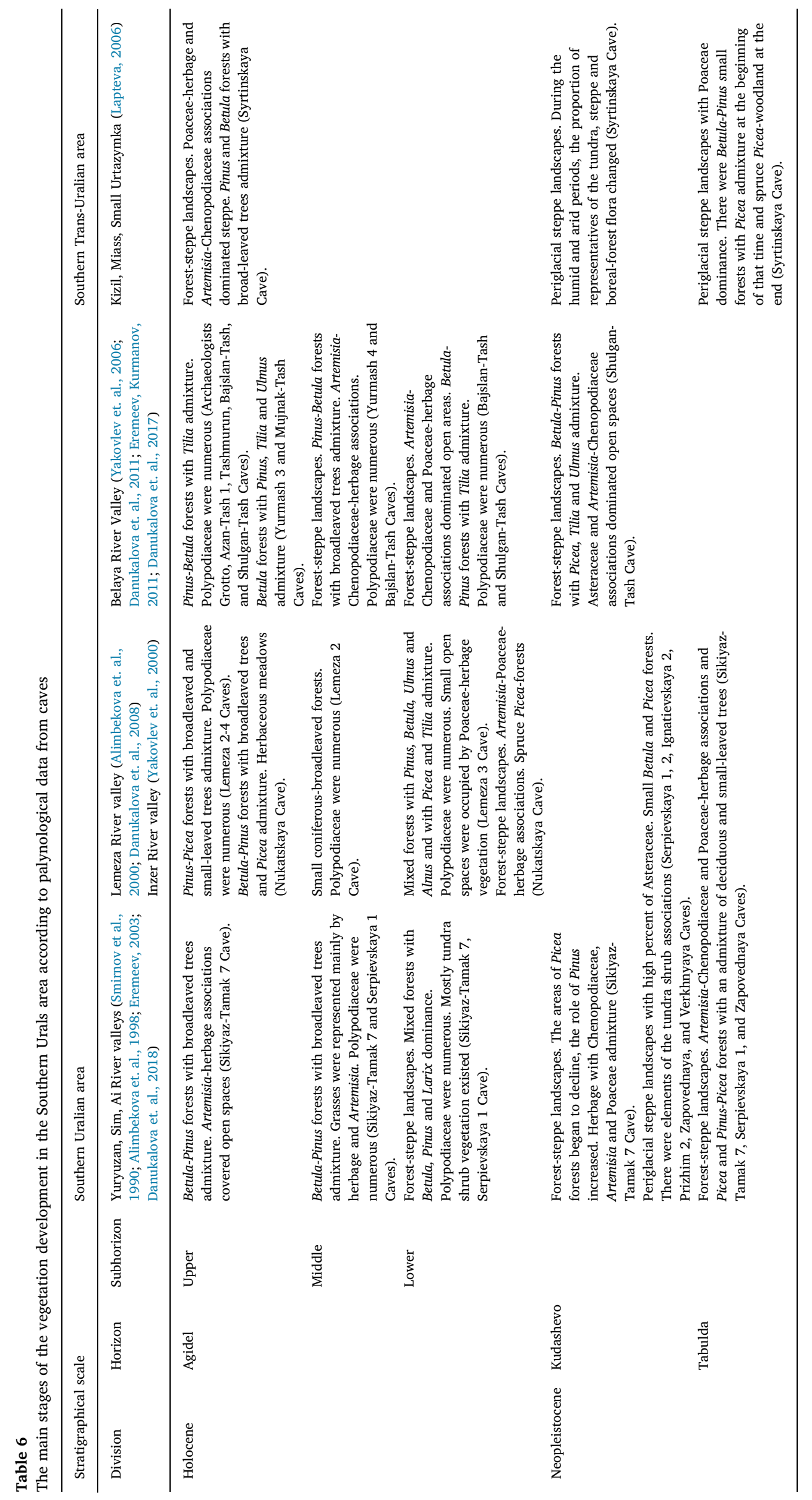


flowing waters with a moderate or slow current, and on the banks were heated backwaters with silted bottom and aquatic vegetation occurred.

\subsection{Ichthyology}

Caves where fish remains were found are located in the basins of the European rivers. The fish remains date to the end of the Middle Neopleistocene, the Late Neopleistocene and the Holocene (Table 8).

The Middle Neopleistocene deposits in the Ignatievskaya and Maiskaya (Serpievskaya 1) Caves yielded 17 fish bones, which belong to 3 different species (Table 8).

Deposits of the lowermost part of the Upper Neopleistocene (MIS 5a-d - 4) from the Sikiyaz-Tamak 7 Cave (layers 12-14) contain only 6 undetermined fish bone remains.

22 bones of 3 species and 29 undetermined fish bone remains were found in the deposits correlated with the middle part of the Upper Neopleistocene (MIS 3) known from Ignatievskaya Cave (1985, pit V, layers 2-9) and Sikiyaz-Tamak 7 Cave (layers 9-11).

Deposits of the uppermost part of the Upper Neopleistocene (MIS 2) from Prizhim 2 Cave, Maiskaya (Serpievskaya 1) Cave (layer 2), Kolokolnaya (Serpievskaya 2) Cave (layers 2-3) and Zapovednaya Cave (layers 1-2) contain 620 bones which belong to 9 different fish species.

The non-stratified Upper Neopleistocene (MIS $5 e-2$ ) deposits of the Imanai Cave contain bones of two fish species - Esox lucius Linnaeus, 1758 and Perca fluviatilis Linnaeus, 1758 (Table 8).

The Lower Holocene cave deposits from the Nukatskaya cave (layer 2) contain 73 bones which were attributed to six species. The deposits of the Middle Holocene excavated in the Sikiyaz-Tamak 7 Cave (layers 5-6) contain four undetermined fish bones.

In total 169 bones of six species were discovered in the Nukatskaya cave (layer 1) in the Upper Holocene deposits.

The non-stratified Holocene (MIS 1) deposits of the Maiskaya (Serpievskaya 1) Cave (layer 1) yielded 738 bones of seven species.

The best represented species in the different assemblages are Thymallus thymallus (Linnaeus, 1758) and Barbatula barbatula (Linnaeus, 1758). The bone remnants of Lota lota (Linnaeus, 1758) and Cottus gobio (Linnaeus, 1758) are not numerous but they are also represented in all the studied deposits (Table 8). The bone remains of the other species are less numerous and the species are not represented in all the assemblages. All the freshwater fish species found in the MiddleUpper Neopleistocene and Holocene cave deposits are widely spread in Europe (Reshetnikov, 1998).

\subsection{Herpetology}

Bones of amphibians and reptiles are known from the unconsolidated Quaternary cave deposits (Fig. 5).

\subsubsection{Amphibians}

Amphibian bone remains were found in the Upper Pleistocene and Holocene deposits (Table 9).

The Upper Pleistocene (Kudashevo Horizon) deposits of the BajslanTash Cave contain rare bones, representing only three species and three genera. Bone remains of the forest species Rana arvalis Nilsson, 1842 and $R$. temporaria Linnaeus, 1758, dominate the assemblage. Lower Holocene deposits of the Lemeza III Cave contain 520 bones of three species and three genera; the typical forest representatives Rana temporaria Linnaeus, 1758 and Bufo bufo (Linnaeus, 1758) dominate the assemblage.

The Middle Holocene deposits of the Bajslan-Tash and Lemeza II Caves and the Maksyutovo Grotto yielded in total 189 bones representing five species and three genera. Bone remains of Rana temporaria Linnaeus, 1758 are most numerous; bones of Lissotriton vulgaris (Linnaeus, 1758) and Bufo viridis Laurenti, 1768 are present. The Middle Holocene association is characterized by forest species and species that prefer open areas.
The Upper Holocene deposits of the Bajslan-Tash cave, the Archaeologists and Tashmurun Grottoes, the Lemeza IV and Zapovednaya Caves yielded in total 6503 amphibian bones from four species and five genera. Bone remains of Rana temporaria Linnaeus, 1758 and Bufo bufo (Linnaeus, 1758) dominate and bone remains of Triturus cristatus (Laurenti, 1768), Bombina sp. and Rana arvalis Nilsson, 1842 are present. This association consists of forest species; Triturus cristatus (Laurenti, 1768) and Bombina sp. inhabit broad-leaved forests.

\subsubsection{Reptiles}

Reptiles bone remains were found in the Upper Pleistocene and Holocene deposits (Table 10).

The Upper Pleistocene Kudashevo Horizon deposits of the BajslanTash cave yielded nine species of seven genera. Bone remains of Lacerta agilis Linnaeus, 1758, Vipera ursinii (Bonaparte, 1835), Anguis fragilis Linnaeus, 1758 and Coronella austriaca Laurenti, 1768 dominate; species are characteristic of steppe and forest biotopes.

The Lower Holocene deposits of the Lemeza III cave yielded three species that inhabit forest and steppe biotopes. The Middle Holocene deposits of the Maksyutovo Grotto, Bajslan-Tash, Yurmash 4 and Lemeza II caves yielded in total 479 remains of 10 species and eight genera. Bone remains are represented mainly by steppe species. Anguis fragilis Linnaeus, 1758, Lacerta agilis Linnaeus, 1758, Vipera ursinii (Bonaparte, 1835) and Coronella austriaca Laurenti, 1768 dominate the assemblages.

The Upper Holocene deposits of the Archaeologists and Tashmurun Grottoes, the Bajslan-Tash, Lemeza IV and Zapovednaya caves yielded in total 519 bone remains of eight species and five genera. Bone remains are represented mainly by forest species. Anguis fragilis Linnaeus, 1758, Natrix natrix (Linnaeus, 1758), Vipera berus (Linnaeus, 1758), Coronella austriaca Laurenti, 1768, and Lacerta agilis Linnaeus, 1758 dominate the association.

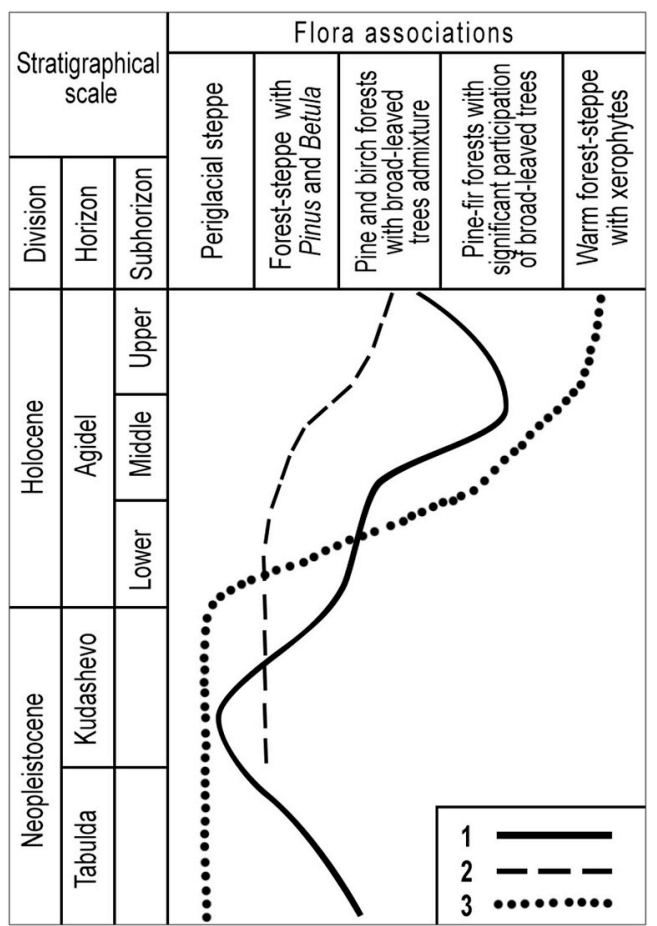

Fig. 3. Reconstruction of the main stages of the development of the flora during the late Late Pleistocene and Holocene in the territory of the Southern Urals and Trans-Urals.

Legend: 1 - the northern zone of the studied Southern Urals mountainous area; 2 - the southern zone of the studed Southern Urals mountainous area; 3 - the Southern Trans-Uralian area. 


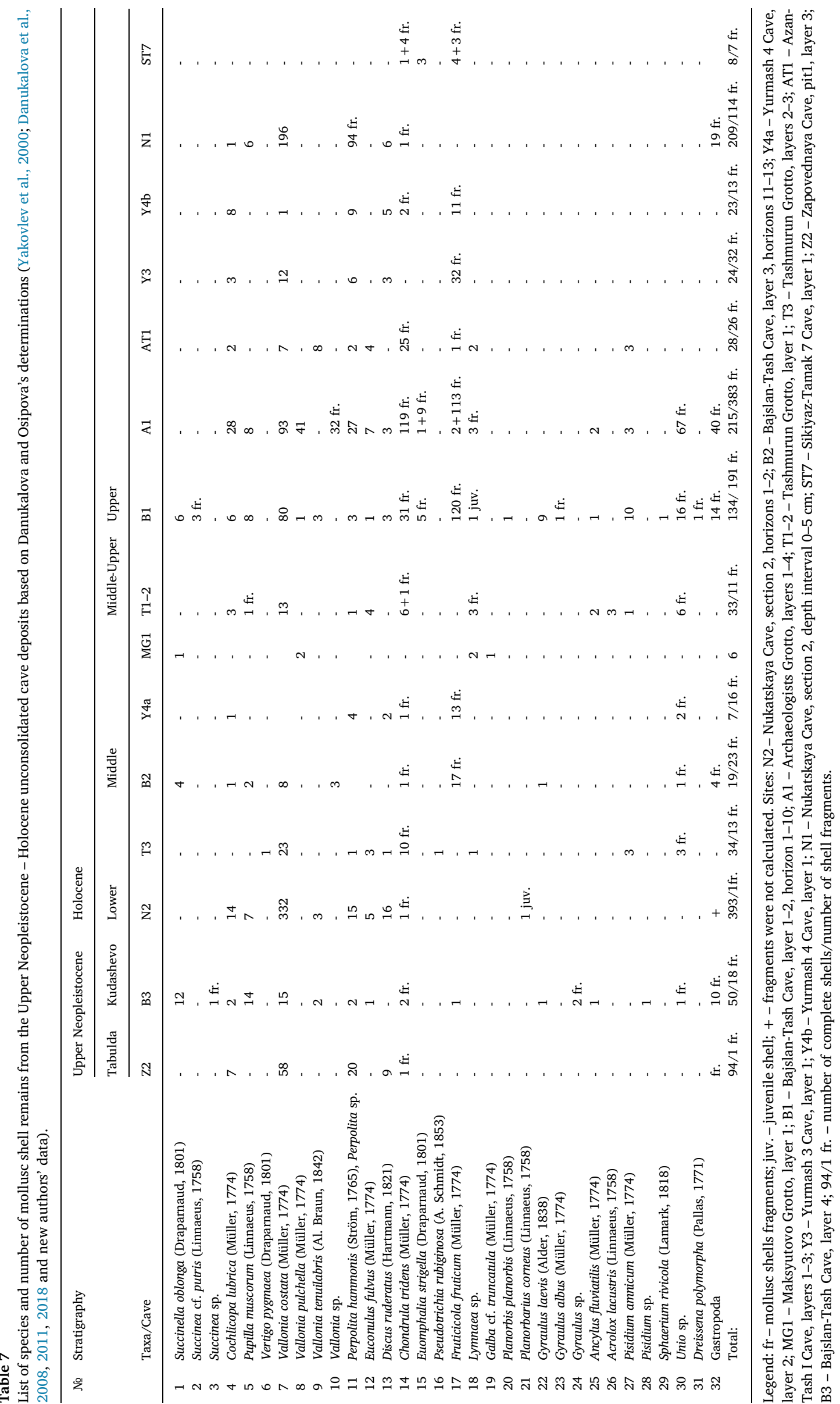




\subsection{Ornithology}

The studied remains of birds were from sediments of a very small number of caves (Yakovlev et al., 2000; Sataev, 2005; Kosintsev et al., 2018; Danukalova et al., 2018). In total 393 bones of 20 different species were found in sediments of the upper part of the Upper Neopleistocene (MIS 2) in the Balatukai Cave (layer 3) (Table 11). Among them there are 6 bones of 5 different species, all living near water bodies, 319 bones of 6 species that prefer open and semi-open landscapes including Lagopus lagopus (Linnaeus, 1758) (the dominant species with 310 records), and 68 bones from 9 species that inhabit enclosed and/or semi-closed landscapes.

The Late Holocene deposits are recorded in Balatukai Cave (layer 1), Atysh Grotto, and Lemeza II Cave (layer 2). These deposits contain 138 bird bones (Table 11) assigned to 13 species that inhabit semi-open landscapes and 22 species that prefer closed habitats. The non-stratified Holocene (MIS 1) deposits recorded in a number of caves (Balatukai Cave, layer 2; Verkhnaya Cave, layer 1; Zapovednaya Cave, layer 1; Nukatskaya Cave, layer 1; Sikiyaz-Tamak 6 Cave, layer 1; SikiyazTamak 10 Cave, layer 1) yielded 243 bird bones (Table 11): 6 species that prefer to live near water bodies, 11 species that inhabit open and semi-open landscapes and 33 species that prefer enclosed and semiclosed habitats. The bones of Lyrurus tetrix (Linnaeus, 1758), Tetrao urogallus Linnaeus, 1758, and Bonasa bonasia (Linnaeus, 1758) are most numerous. The remaining species are represented by single bones. All bird species found in the cave sediments, except for the ring ouzel Turdus torquatus Linnaeus, 1758, inhabit currently the Southern Urals territory.

\subsection{Mammalogy}

\subsubsection{Small mammals}

Small-mammal bone remains are known from Upper Pleistocene and Holocene deposits in caves (Table 12, Figs. 6 and 7).

The Upper Pleistocene Kudashevo Horizon deposits in the BajslanTash cave located in the Belaya River valley yielded 31 different taxa including steppe species such as Lagurus lagurus (Pallas, 1773), Microtus gregalis (Pallas, 1779), Cricetulus migratorius (Pallas, 1773), Allocricetulus eversmanni (Brandt, 1894), and Ochotona sp. (Table 12). The assemblage dates to the end of the Kudashevo time.

Lower Holocene deposits with small-mammal remains were recorded in the central part of the Southern Urals - in the caves located in the Lemeza and Inzer River valleys. The 3191 fossil remains are assigned to 33 taxa (Table 12). The share of steppe species (Microtus gregalis (Pallas, 1779), Lagurus lagurus (Pallas, 1773), Ochotona sp., Cricetulus migratorius (Pallas, 1773), and Alactagulus sp.) is high in the

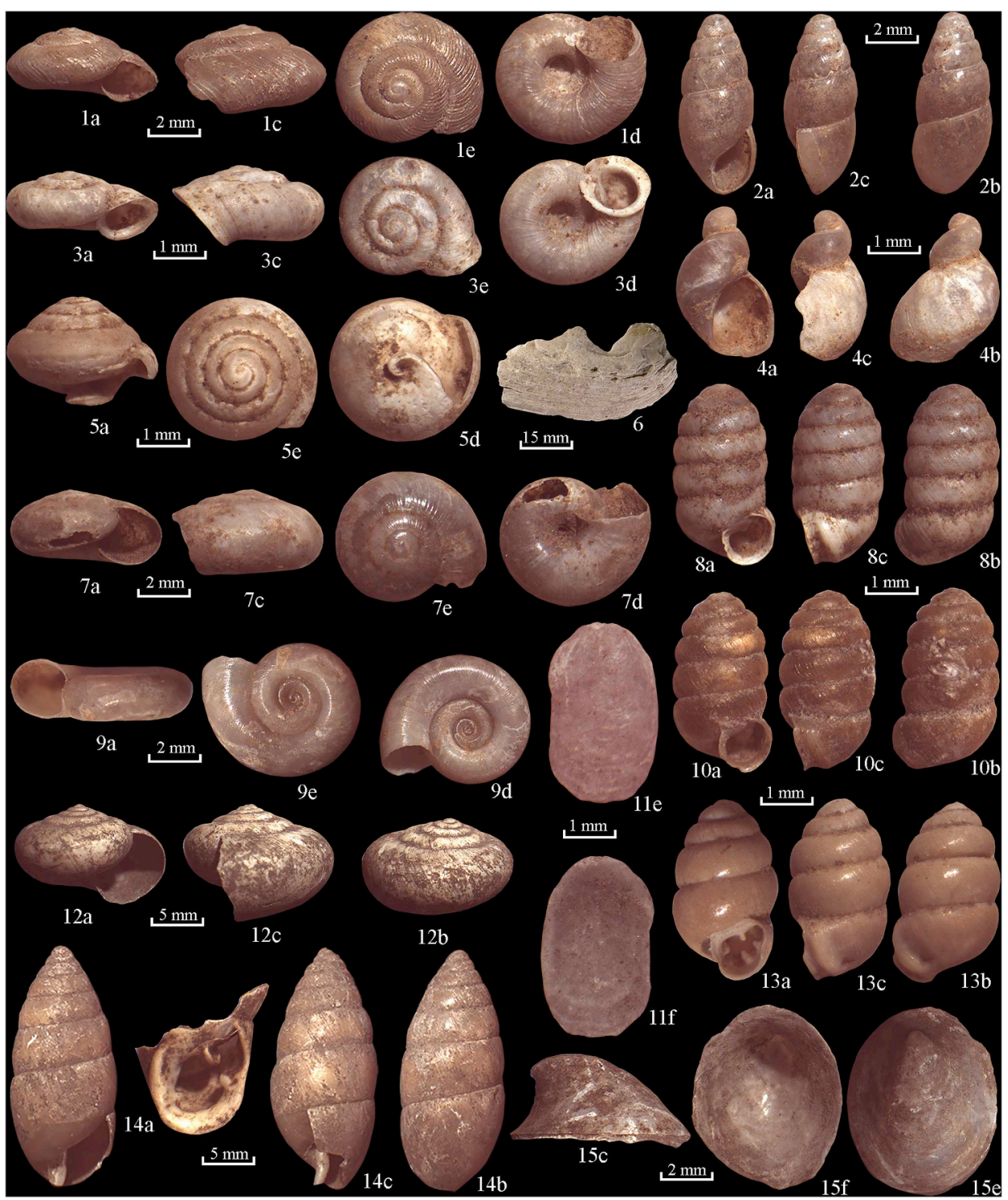

Fig. 4. Key-species of molluscs found in the Upper Pleistocene - Holocene unconsolidated cave deposits, Southern-Urals region, Russia. Legend: 1 - Discus ruderatus (Fer.), IG 50/988/2; 2 - Cochlicopa lubrica (Müll.), IG 50/988/4; 3 Vallonia costata (Müll.), IG 21/1114/7; 4 Succinella oblonga (Drap.) (juvenile form), IG 21/ 1117/9; 5 - Euconulus fulvus (Müll.), IG 21/ 1291/6; 6 - Unio sp. (shell fragment), IG 21/ 1114/11; 7 - Perpolita hammonis (Ström), IG 22/ 990/17; 8 - Pupilla muscorum (L.), IG 22/989/ 16; 9 - Gyraulus laevis (Alder), IG 21/1112/24; 10 - Pupilla muscorum (L.), IG 21/1112/25; 11 Limax sp., IG 68/1285/40; 12 - Fruticicola sp. (juvenile form), IG 21/1083/35; 13 - Vertigo pygmaea (Drap.), IG 68/1284/39; 14 - Chondrula tridens (Müll.), IG 21/1085/36; 15 - Ancylus fluviatilis Müll., IG 68/1285/41; a - apertural view; $\mathrm{b}$ - abapertural view (view from the opposite side of the aperture); $\mathrm{c}$ - lateral view (top right); $\mathrm{d}$ - umbilical view; e - apical view; $\mathrm{f}$ basal view (view from the opposite apical side). 1 and 2 - Tabulda Horizon; 3-6 - Kudashevo Horizon; 7 and 8 - Lower Holocene; 9 and $10-$ Middle Holocene; 11-15 - Upper Holocene. 


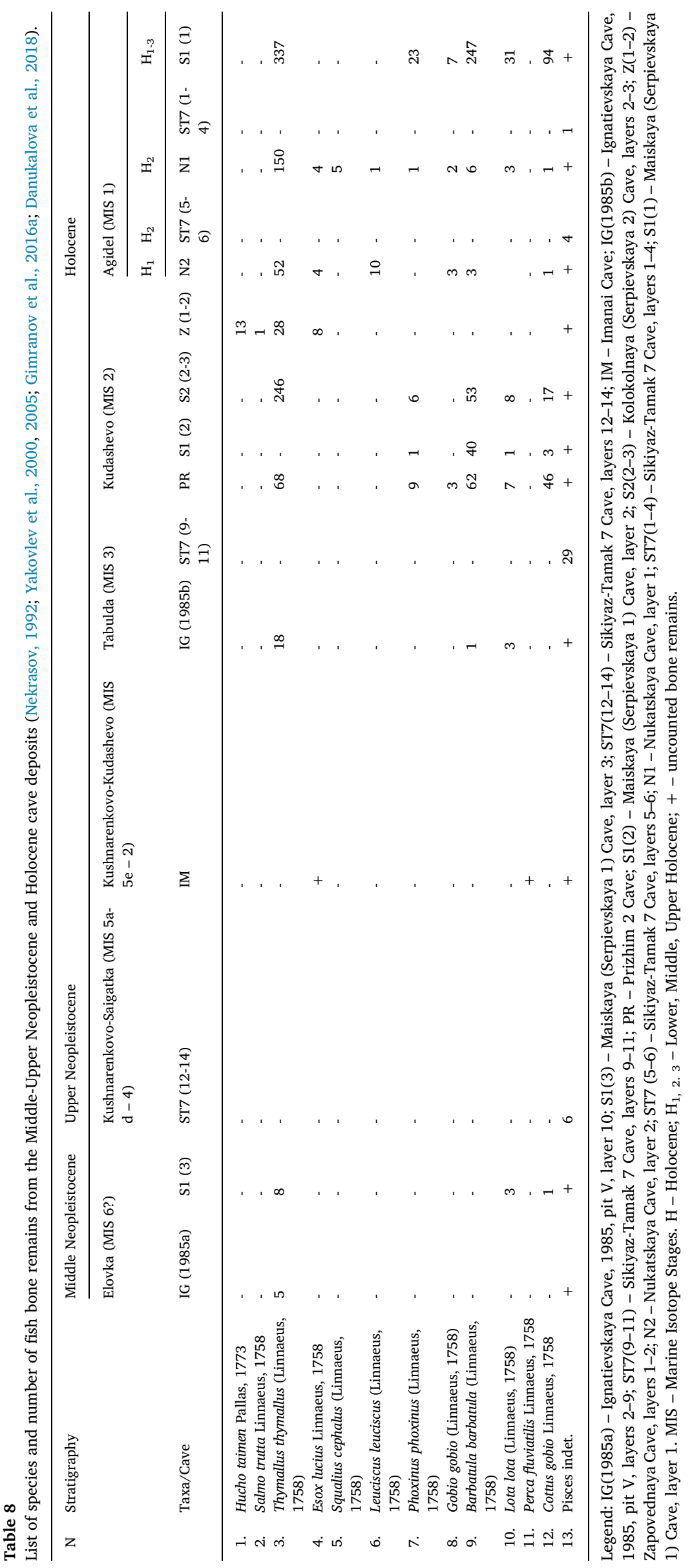



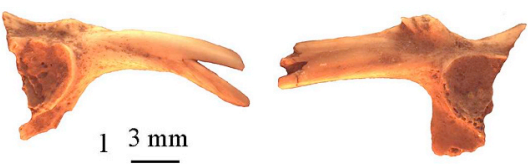

2

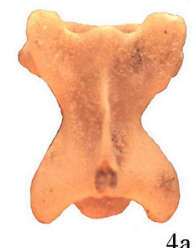

$4 \mathrm{a}$
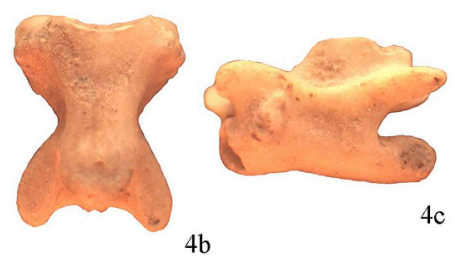

$4 \mathrm{c}$
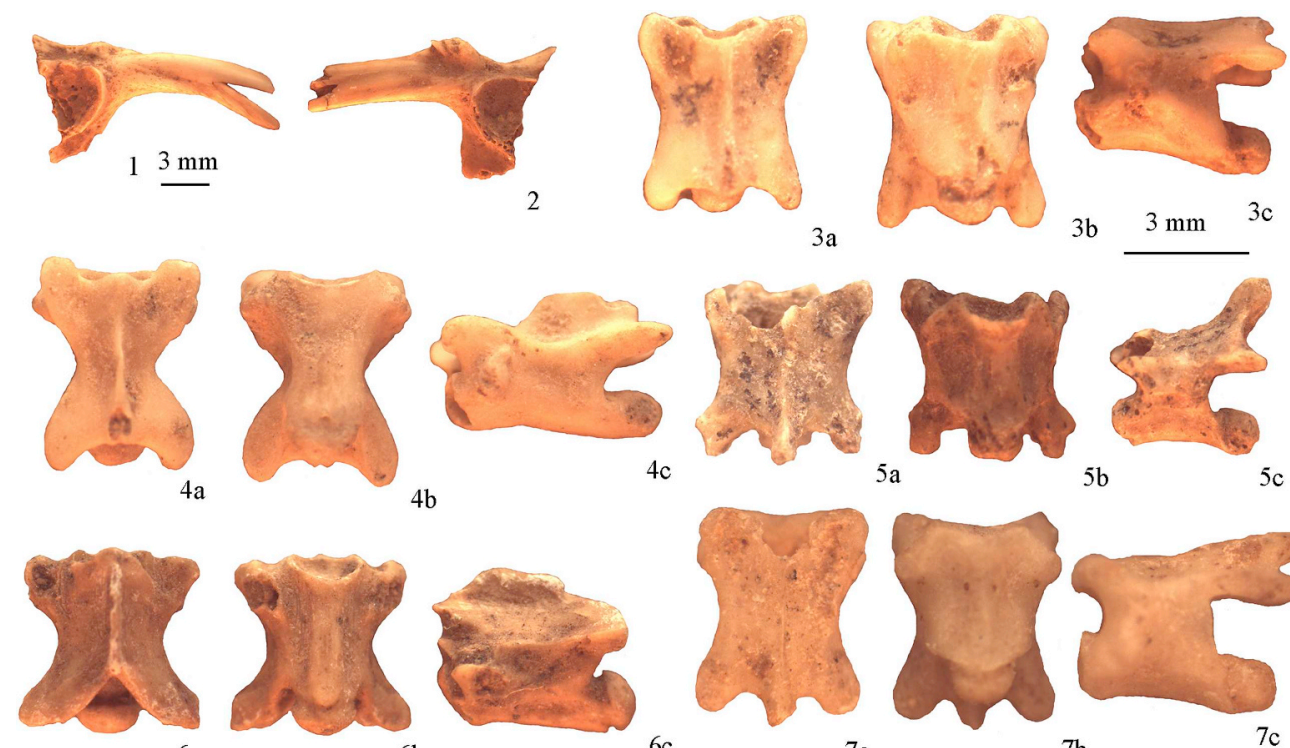

$6 \mathrm{~b}$
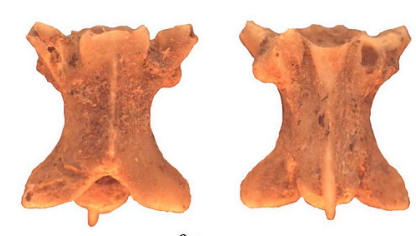

$8 \mathrm{a}$

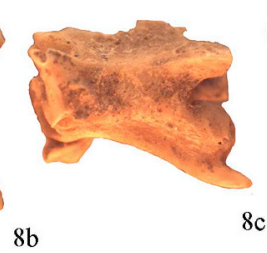

$6 c$
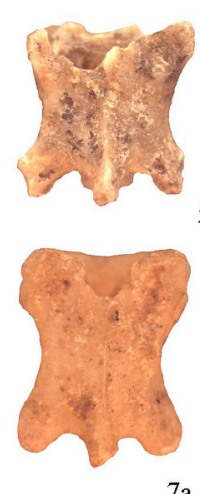

$5 \mathrm{a}$
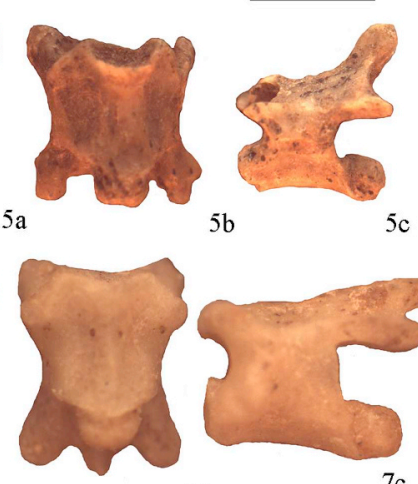

$7 \mathrm{a}$
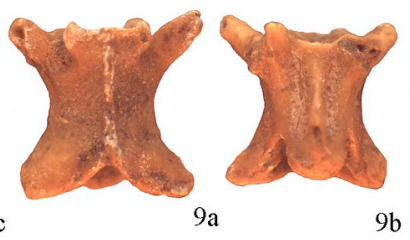
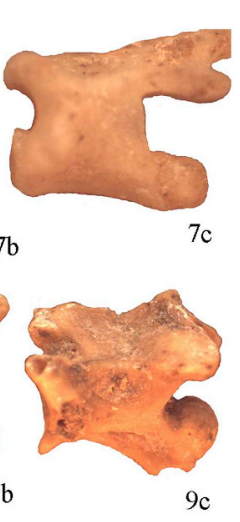

Fig. 5. Key-species of amphibians and reptiles found in the Upper Pleistocene Holocene unconsolidated cave deposits, Southern-Urals region, Russia.

Legend: 1 - Bufo bufo (Linnaeus, 1758), ilium, Lemeza IV cave, layers 1-3; 2 - Rana temporaria Linnaeus, 1758, ilium, Lemeza IV cave, layers 1-3; 3 - Eremias cf. arguta (Pallas, 1773), trunk vertebra, Bajslan-Tash cave, layer 3; 4 - Anguis fragilis Linnaeus, 1758, trunk vertebra, Maksyutovo Grotto, layer 1; 5 - Lacerta agilis Linnaeus, 1758, trunk vertebra, Bajslan-Tash cave, layers 1-2; 6 - Coronella austriaca Laurenti, 1768, trunk vertebra, Bajslan-Tash cave, layers 1-2; 7 - Zootoca vivipara (Jacquin, 1787), trunk vertebra, Maksyutovo Grotto, layer 1; 8 - Vipera ursinii (Bonaparte, 1835), trunk vertebra, Bajslan-Tash cave, layer 4; 9 Vipera berus (Linnaeus, 1758), trunk vertebra, Bajslan-Tash cave, layers 1-2; 10 Natrix natrix (Linnaeus, 1758), trunk vertebra, Bajslan-Tash cave, layers 1-2; a - top view, b - basal view, c - lateral view. $1,2,5$, 6, 9, 10 - Upper Holocene; 3, 4, 7 - Middle Holocene, 8 - Upper Pleistocene, Kudashevo Horizon.
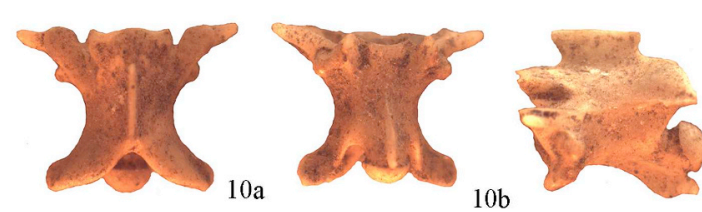

$3 \mathrm{~mm}$

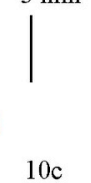

Early Holocene mammalian association. Clethrionomys rufocanus (Sundevall, 1846) and $\mathrm{Cl}$. ex gr. glareolus-rutilus prefer forest biotopes whereas Dicrostonyx torquatus (Pallas, 1778), which is rare, indicates a tundra environment.

There are two localities in the northern part of the studied region (the Ufimian Plateau) (Alikaev Kamen site and Bobyliok Grotto, layer 2) with unconsolidated deposits that yielded 2261 small-mammalian fossil remains assigned to 27 taxa with steppe (Microtus gregalis (Pallas, 1779), Lagurus lagurus (Pallas, 1773), Eolagurus luteus (Everssmann, 1840), Cricetulus migratorius (Pallas, 1773), Spermophilus sp.), forest (Clethrionomys sp., Apodemus sp.) and tundra (Dicrostonyx sp.) dwellers.

Middle Holocene deposits with small mammal remains are known from the central and southern parts of the studied area from the Belaya and Lemeza River valleys. The recorded 5854 small mammal remains are from 32 different taxa. Steppe species (Microtus gregalis (Pallas, 1779), Lagurus lagurus (Pallas, 1773), and Ochotona sp.) dominate the assemblage; the share of species that prefer a forested biotope (Clethrionomys ex gr. glareolus-rutilus and representatives of Apodemus sp.) increased.

Upper Holocene deposits are recorded in six caves of the central and southern parts of the Southern Urals - in the Belaya and Lemeza River valleys. The 6114 small mammal remains are attributed to 31 taxa (Table 11). A significant part of the represented species are forest dwellers e.g. Clethrionomys ex gr. glareolus-rutilus, Cl. rufocanus (Sundevall, 1846), Microtus agrestis (Linnaeus, 1761), Talpa europaea Linnaeus, 1758 and representatives of Apodemus genus. At the end of the Holocene, species that prefer steppe habitats almost disappeared from the mountainous part of the Southern Urals.

\subsubsection{Large mammals}

The more ancient mammal faunas have been discovered in the Ignatievskaya Cave (1985, pit V, layer 10), Maiskaya (Serpievskaya 1) Cave (layer 3) and Verkhnaya Cave. The faunal assemblage includes Middle Pleistocene key-species: the fossil lemming Dicrostonyx simplicior Fejfar, 1966, and the large mammals Ursus cf. deningeri Richenau, 1904, and Stephanorhinus cf. kirchbergensis Jäger, 1839 (Smirnov et al., 1990, Table 13). Faunas from the Ignatievskaya and Serpievskaya Caves described as "Serpievskaya" fauna (Smirnov et al., 1990) are dated to the Middle Pleistocene and are correlated with the Middle Neopleistocene Elovka time (MIS 6?) (Table 13).

Mammalian faunas from Ignatievskaya Cave (2014, pit V, layer 10), Barsuchyi Dol Cave and Bobyliok Grotto (layers 5-6) include Hystrix brachyura Linnaeus, 1758, Mustela lutreola (Linnaeus, 1761), Stephanorhinus cf. kirchbergensis Jäger, 1839 (Table 13), Sciurus vulgaris (Linnaeus, 1758), Apodemus flavicollis (Melchior, 1834), Dryomys nitedula (Pallas, 1778) (Smirnov, 1993; Fadeeva et al., 2018, 2019), species that indicate interglacial conditions. Other species indicate a Late Neopleistocene age (Smirnov, 1993; Fadeeva et al., 2018, Table 13) and the enamel differentiation coefficient (SDQ) of the Arvicola terrestris molars (Heinrich, 1982) suggests a Late Pleistocene age (Fadeeva et al., 2018, 2019). Based on the different features, the faunas are attributed to the first half of the Late Neopleistocene Kushnarenkovo time (MIS 5e).

Faunas from Ignatievskaya Cave (pit V, layers 2-9), Sikiyaz-Tamak 7 Cave (layers 9-11), Kozya (Asha I) Cave, Zapovednaya Cave, Kinderlinskaya Cave, and Smelovskaya 2 Cave include Ursus spelaeus Rosenmüller, 1794 and Crocuta crocuta spelaea (Goldfuss, 1823) (Table 13); these species dissapeared at the end of MIS 3 (Pacher, 
Table 9

List of species and number of amphibian bone remains from the Upper Neopleistocene - Holocene unconsolidated cave deposits; identification by T. Yakovleva (Yakovlev et al., 2003, 2004, 2005; Danukalova et al., 2008, 2011).

\begin{tabular}{|c|c|c|c|c|c|c|c|c|c|c|c|}
\hline \multirow[t]{3}{*}{ № } & \multirow{3}{*}{$\begin{array}{l}\text { Stratigraphy } \\
\text { Taxa/Cave }\end{array}$} & \multirow{3}{*}{$\begin{array}{l}\text { Upper Neopleistocene } \\
\text { Kudashevo horizon } \\
\text { B3 }\end{array}$} & \multicolumn{9}{|c|}{ Holocene } \\
\hline & & & \multirow{2}{*}{$\begin{array}{c}\text { Lower } \\
\text { L3a }\end{array}$} & \multicolumn{3}{|c|}{ Middle } & \multicolumn{5}{|c|}{ Upper } \\
\hline & & & & B2 & MG1 & L2a & $\mathrm{B} 1$ & A1 & $\mathrm{T} 1-2$ & L4 & $\mathrm{Z} 4$ \\
\hline 1 & Lissotriton vulgaris (Linnaeus, 1758) & - & - & - & 1 & - & - & - & - & - & - \\
\hline 2 & Triturus cristatus (Laurenti, 1768) & - & - & - & - & - & - & - & - & - & 1 \\
\hline 3 & Bombina sp. & - & - & - & - & - & - & - & - & 1 & - \\
\hline 4 & Pelobates cf. fuscus (Laurenti, 1768) & 1 & - & - & - & - & 1 & - & - & - & - \\
\hline 5 & Bufo bufo (Linnaeus, 1758) & - & 24 & - & 1 & 9 & 2 & - & - & 391 & - \\
\hline 6 & B. cf. bufo & - & - & - & - & - & - & - & 1 & - & - \\
\hline 7 & B. viridis Laurenti, 1768 & - & - & - & 1 & - & - & - & - & - & - \\
\hline 8 & Bufo sp. & 1 & 4 & - & 1 & - & 1 & - & 1 & - & - \\
\hline 9 & Rana arvalis Nilsson, 1842 & 19 & 2 & 7 & 3 & - & 2 & - & 2 & - & - \\
\hline 10 & $R$. cf. arvalis & 1 & - & 1 & - & - & 2 & - & - & - & - \\
\hline 11 & R. temporaria Linnaeus, 1758 & 8 & 140 & - & 14 & 32 & 9 & 1 & 2 & 1892 & 3 \\
\hline 12 & R. cf. temporaria & - & - & 1 & - & - & 1 & - & - & - & - \\
\hline 13 & Rana sp. & 7 & 51 & 4 & 6 & - & 3 & 2 & 8 & - & - \\
\hline \multirow[t]{2}{*}{14} & Anura indet. & 7 & 299 & 10 & 8 & 90 & 5 & 1 & 8 & 4150 & 13 \\
\hline & Total: & 44 & 520 & 23 & 35 & 131 & 26 & 4 & 22 & 6434 & 17 \\
\hline
\end{tabular}

Legend: B3 - Bajslan-Tash Cave, layer 4; L3a - Lemeza III Cave, layers 2-6; B2 - Bajslan-Tash Cave, layer 3; MG1 - Maksyutovo Grotto, layer 1; L2a - Lemeza II Cave, layer 2; B1 - Bajslan-Tash Cave, layers 1-2; A1 - Archaeologists Grotto, layers 1-4; T1-2 - Tashmurun Grotto, layers 1, 2; L4 - Lemeza IV Cave, layers 1-3; Z4 Zapovednaya Cave, pit 3, layers 1-2.

Stuart, 2009; Stuart, Lister, 2014). This fact and the series of the radiocarbon dates (Table 4) permitted to correlate these faunas with the Late Pleistocene Tabulda period (MIS 3). The fauna from the SikiyazTamak 7 Cave (layers 12-14) includes Late Pleistocene key-species
(Kosintsev and Bachura, 2013, Table 13). The age of the fauna is beyond the radiocarbon dating range (Table 4 ) and is, therefore, attributed to the Late Neopleistocene Kushnarenkovo-Saigatka (MIS 5a-d - 4) time interval.

Table 10

List of species and number of reptile bone remains from the Upper Neopleistocene and Holocene cave deposits; identification by T. Yakovleva (Yakovlev et al., 2003, 2004, 2005; Danukalova et al., 2008, 2011).

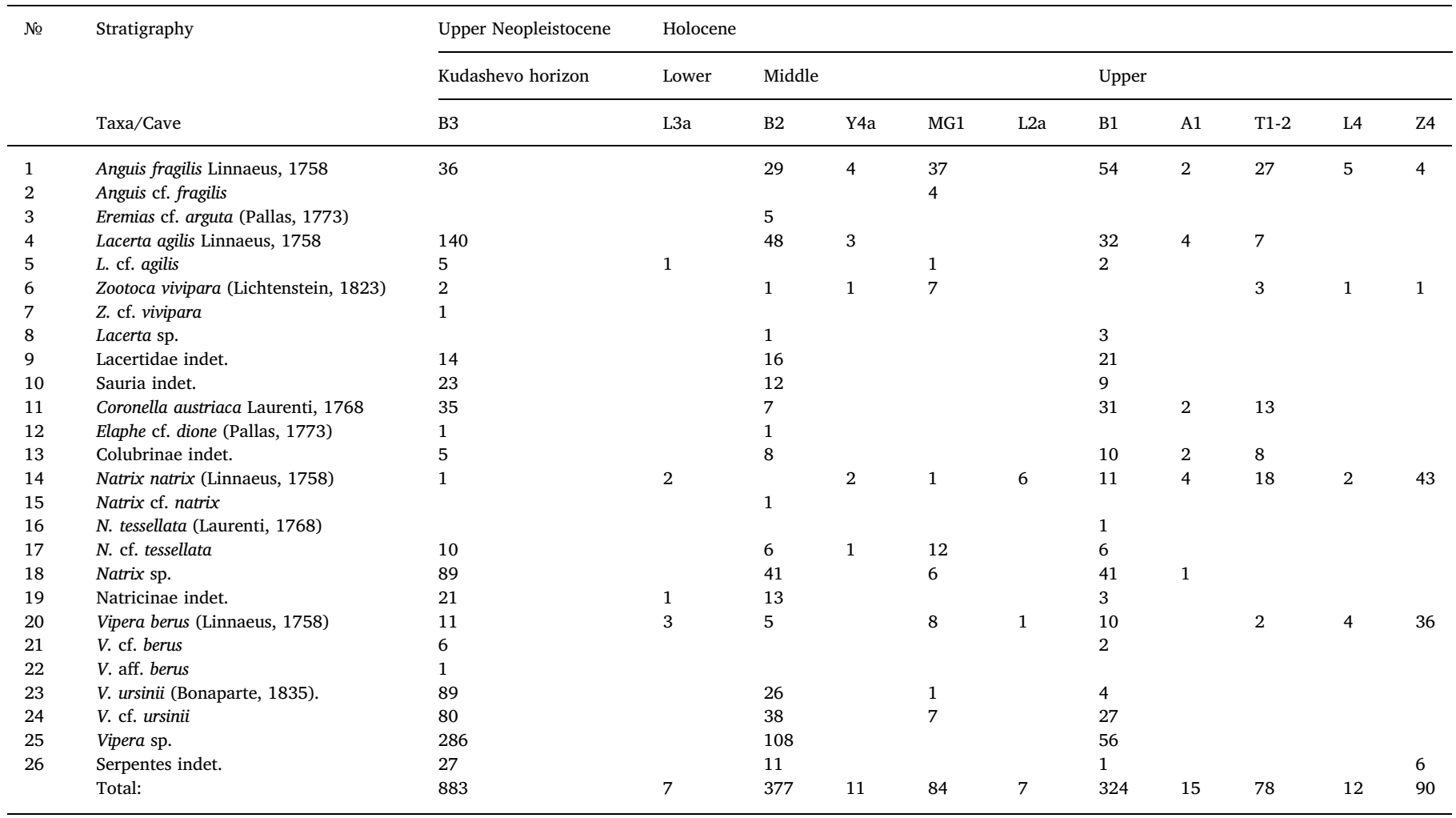

Legend: B3 - Bajslan-Tash Cave, layer 4; L3a - Lemeza III Cave, layers 2-6; B2 - Bajslan-Tash Cave, layer 3; Y4a - Yurmash 4 Cave, layers 2-3; MG1 - Maksyutovo Grotto, layer 1; L2a - Lemeza II Cave, layer 2; B1 - Bajslan-Tash Cave, layers 1-2; A1 - Archaeologists Grotto, layers 1-4; T1-2 - Tashmurun Grotto, layers 1, 2; L4 Lemeza IV Cave, layers 1-3; Z4 - Zapovednaya Cave, pit 3, layers 1-2. 
Large and small-mammal faunas from a series of caves (Bobyliok Grotto (layer 4), Sikiyaz-Tamak 7 Cave (layer 8), Maiskaya (Serpievskaya 1) Cave (layer 2), Syrtinskaya Cave (layer 3), Prizhim 2 Cave, Shulgan-Tash Cave, Kulyurt-Tamak Cave, Bajslan-Tash Cave (layer 4, lower part), Maksyutovo Grotto, Balatukai Cave, Ustinovo Grotto (layer 3)) do not contain Middle Pleistocene, Kushnarenkovo, Tabulda or Holocene key-species (Kosintsev and Bachura, 2013, Table 13). Based on the radiocarbon dates, these faunas are attributed to the Kudashevo time interval (MIS 2) (Table 4).

Analysis of the composition of large and small mammal faunas from the Idrisovo and Imanai Caves (Kosintsev and Bachura, 2013; Gimranov et al., 2018, Table 13) as well as the radiocarbon dates (Table 4) demonstrate that the deposits from these caves are stratigraphically mixed.

\section{Discussion and palaeoenvironment reconstructions}

\subsection{Stratigraphy and chronology}

The lithology of the deposits combined with the radiocarbon dates (this paper, sections 4.1 and 5.1) form the base of the subdivision of the studied unconsolidated deposits in caves into the following, regionally defined, time intervals: Middle Pleistocene (possibly MIS 6), Upper Pleistocene with Kushnarenkovo (MIS 5), Saigatka (MIS 4), Tabulda (MIS 3), and Kudashevo (MIS 2) Horizons and the Holocene represented by the Agidel (MIS 1) Horizon. This subdivision corresponds to the subdivision of similar deposits in the Southern Fore-Uralian area with a detailed stratigraphic succession of radiocarbon dated Upper Pleistocene continental deposits with archaeological and palaeontological finds (Danukalova, 2010; Yakovlev et al., 2013c; Danukalova et al., 2014).

\subsection{Palynology}

The Southern Trans-Urals. During the Late Pleistocene, periglacial steppe landscapes with Poaceae prevailed in the southern part of this area (Tanalyk River valley; Kosintsev et al., 2013) and forest-steppe and forest landscapes dominated in the northern part (Ural, Ui, Bolshoi Kizil, Kumach River valleys; Yakhemovich, 1965). During the Holocene forest-steppe landscapes dominated, with an increase of forested areas.

The same trend is recorded in other areas in the Urals. For example, the Late Pleistocene palynocomplexes of the Tanalyk River valley (Kosintsev et al., 2013) demonstrate the change of the solonchak Artemisia-Chenopodiaceae-herbage steppes at the end of the Tabulda time to more mesophilious herbage-Artemisia-Chenopodiaceae meadowsteppe associations during the Kudashevo time interval. During the Early and Middle Holocene, a rise in tree pollen is noted, in which Pinus pollen gradually begins to predominate, and at the very end of the Middle Holocene pollen sequence broad-leaved species (Tilia cordata) appears. During the Late Holocene, the areas of open habitat, Artemisia steppes, increased.

The Southern Urals. During the second part of the Late Pleistocene, coniferous-leaved forests existed which were replaced by periglacial steppe and forest-steppe during the Kudashevo time interval. During Holocene time there was a gradual increase of forested areas. It should be noted that during the Middle Holocene the climate was warmer and more humid in the northern zone than in the southern zone, as indicated in the pollen spectra by a higher proportion of pollen of broadleaved species.

The Southern Fore-Urals. The change of plant associations in the Southern Fore-Urals and in the Southern Urals proceeded in a similar way. Among the differences, it should be noted that during the Holocene, the forestation on the plains was higher than in the mountains.

During the Tabulda time interval, Picea-Pinus forests with a significant admixture of Abies dominated in the northern part of the territory of the Southern Fore-Urals region, whereas in the southern part forest-steppe dominated. A Chenopodiaceae-Artemisia-herbage steppe association covered the water interfluves and a Picea forests biocoenosis occupied the river valleys (Danukalova et al., 2016).

The vegetation during the Kudashevo time interval consisted of herbage-Artemisia-Chenopodiaceae meadow-steppe associations covering most of the territory, and in the low, more humid places - Picea forests with an admixture of birch trees existed (Nemkova, 1976).

During the Early Holocene Pinus forests with Picea, Betula and broad-leaved trees admixture dominated and ArtemisiaChenopodiaceae-herbage meadow-steppe associations covered the open areas. The Middle Holocene pollen spectra indicate coniferous-deciduous forests (dominated by Pinus, Picea, and Betula) and meadow-steppe associations. Among the trees there is a high proportion of pollen from warm-loving broad-leaved species (Tilia, Quercus, and Ulmus). The spectrum of grasses becomes, compared to the Early Holocene, more diverse.

During the Late Holocene pollen of Pinus, Picea, and Betula dominate the spectra; the proportion of pollen of the broad-leaved trees (Tilia, Quercus, and Ulmus) is, compared to the Middle Holocene time interval, reduced. Artemisia-Chenopodiaceae-herbage meadow-steppe associations grew in the open areas (Danukalova et al., 2014).

\subsection{Malacology}

We would like to compare the data of the malacological complexes from the studied Upper Pleistocene - Holocene subaerial deposits in caves with published data from deposits of the same genesis and the same stratigraphical units from the adjacent territories, however, this kind of information is lacking. Therefore we compared our data with malacological data extracted from the deposits of different genesis (subaerial - loess, or loess-like loam, lacustrine and fluvial clay and sand) from the same Upper Pleistocene - Holocene stratigraphical intervals. The species composition of molluscs from the Southern Uralian caves resembles the malacocomplexes of other regions in the Urals, Trans-Urals and Siberia (Stefanovsky, 2006; Sato et al., 2014; Danukalova et al., 2015; Khenzykhenova et al., 2019; Osipova et al., 2018). The molluscs are represented by modern species, which live under severe continental climate conditions with cold winters and warm summers. Malacocomplexes described from the Central Russian territory (Danilovskyi, 1955), Ukraine (Gozhik, 1965; Veklich and Sirenko, 1972; Kunitsa, 2007; Alexandrowicz, Dmytruk, 2007; Alexandrowicz et al., 2014) and Europe (Monnier, 1980; Alexandrowicz S., 1986; Fükon, 1987; Alexandrowicz S. and Alexandrowicz W., 1995a, b, 2010; Alexandrowicz W., 1999, 2001, 2002, 2009, 2011a, b, 2013a, b, c, 2014, 2018; Lozek, 2000; Sümegi and Krolopp, 2002, Marković et al., 2004, 2006, 2007, 2008; Martin et al., 2005; Dobrowolski, 2005; Moine et al., 2005; Moine, 2008 ; Cieszkowski et al., 2010; Sümegi et al., 2011; Dobrowolski et al., 2012; Alexandrowicz and Rybska, 2013; Danukalova et al., 2013, 2017a) also consist of geographically widely distributed mollusc species but among them there are warm-loving species which are completely absent in Urals because of the more severe climatic conditions.

\subsection{Ichthyology}

Fish remains were discovered in the deposits assigned to the uppermost part of the Middle Neopleistocene (Elovka Horizon, MIS 6?), the Upper Neopleistocene (Kushnarenkovo-Saigatka Horizons, MIS 5a-d - 4; Tabulda Horizon, MIS 3; Kudashevo Horizon, MIS 2) and to the Holocene (Lower, Middle and Upper Holocene; MIS 1) (Table 10).

In total 13 fish' species were identified. Two species (Thymallus thymallus (Linnaeus, 1758), Lota lota (Linnaeus, 1758)) were present in all studied deposits. One species (Barbatula barbatula (Linnaeus, 1758)) was discovered in the Upper Neopleistocene and the Holocene deposits. Three species (Esox lucius Linnaeus, 1758, Phoxinus phoxinus (Linnaeus, 
Table 11

List of species and number of birds bone remains in the Upper Neopleistocene and Holocene cave deposits (Yakovlev et al., 2000; Sataev, 2005; Kosintsev et al., 2018; Danukalova et al., 2018).

\begin{tabular}{|c|c|c|c|c|c|c|c|c|c|c|c|}
\hline \multirow[t]{3}{*}{ N } & \multirow{3}{*}{$\begin{array}{l}\text { Stratigraphy } \\
\text { Taxa/Cave }\end{array}$} & \multirow{3}{*}{$\begin{array}{l}\text { Upper Neopleistocene } \\
\text { Kudashevo (MIS 2) } \\
\text { BT3(3) }\end{array}$} & \multicolumn{9}{|c|}{ Holocene (MIS 1) } \\
\hline & & & \multirow{2}{*}{$\begin{array}{l}\text { Lower-Middle } \\
\text { BT(2) }\end{array}$} & \multicolumn{5}{|c|}{ Lower-Upper } & \multicolumn{3}{|l|}{ Upper } \\
\hline & & & & $\mathrm{V}(1)$ & $\mathrm{Z}(1)$ & $\mathrm{N}(1)$ & ST6(1) & ST10(1) & $\mathrm{BT}(1)$ & AG & L2a \\
\hline 1 & Podiceps cristatus (Linnaeus, 1758) & - & - & - & - & - & - & - & - & - & + \\
\hline 2 & Podiceps auritus (Linnaeus, 1758) & $1^{*}$ & - & - & - & - & - & - & - & - & - \\
\hline 3 & Podiceps sp. & - & - & & & & & & 1 & & \\
\hline 4 & Anas platyrhynchos Linnaeus, 1758 & 1 & - & - & - & - & + & - & - & - & - \\
\hline 5 & Anas crecca Linnaeus, 1758 & - & - & - & - & - & + & - & - & - & - \\
\hline 6 & Anas ex gr. crecca-querquedula & - & - & - & - & + & - & - & - & - & - \\
\hline 7 & Anas acuta (Linnaeus, 1758) & - & - & - & - & - & - & - & 1 & - & - \\
\hline 8 & Anas querquedula (Linnaeus, 1758) & 1 & - & - & + & - & - & - & - & - & - \\
\hline 9 & Anas strepera (Linnaeus, 1758) & - & - & - & - & - & + & - & - & - & + \\
\hline 10 & Bucephala clangula (Linnaeus, 1758) & 1 & - & - & - & - & - & - & - & - & - \\
\hline 11 & Anatidae indet. & - & - & - & - & - & - & + & 2 & - & - \\
\hline 12 & Accipiter nisus (Linnaeus, 1758) & - & - & - & - & - & + & - & - & + & + \\
\hline 13 & Buteo buteo (Linnaeus, 1758) & - & - & - & - & - & - & + & - & - & - \\
\hline 14 & Buteo sp. & - & 1 & - & - & - & - & - & - & - & - \\
\hline 15 & Circus pygargus (Linnaeus, 1758) & 1 & - & - & - & - & - & - & - & - & - \\
\hline 16 & Falco ex gr. rusticolus-cherrug & - & - & - & - & - & + & - & - & - & - \\
\hline 17 & Falco subbuteo Linnaeus, 1758 & - & - & - & - & - & + & + & - & + & - \\
\hline 18 & Cerchneis tinnunculus Linnaeus, 1758 & 8 & 1 & - & - & - & - & - & 1 & - & - \\
\hline 19 & Falconidae indet. & 2 & - & + & + & - & - & - & - & - & - \\
\hline 20 & Perdix perdix (Linnaeus, 1758) & - & - & - & - & - & - & - & - & + & + \\
\hline 21 & Lagopus lagopus (Linnaeus, 1758) & 310 & 57 & - & - & - & + & + & 2 & - & - \\
\hline 22 & Lagopus muta (Montin, 1776) & - & 1 & - & - & - & - & - & - & - & - \\
\hline 23 & Lagopus sp. & - & 6 & & & & & & - & & \\
\hline 24 & Lyrurus tetrix (Linnaeus, 1758) & 19 & 46 & - & - & + & + & + & 118 & - & - \\
\hline 25 & Tetrao urogallus Linnaeus, 1758 & 2 & 31 & - & - & + & + & - & 35 & - & - \\
\hline 26 & Bonasia bonasia (Linnaeus, 1758) & 4 & 43 & - & - & - & - & - & 64 & - & - \\
\hline 27 & Tetraonidae indet. & 1 & - & - & + & - & - & - & 1 & - & - \\
\hline 28 & Coturnix coturnix (Linnaeus, 1758) & - & - & - & - & - & - & - & 1 & - & - \\
\hline 29 & Galliformes indet. & - & - & - & - & - & - & - & 6 & - & - \\
\hline 30 & Crex crex (Linnaeus, 1758) & 1 & 3 & - & - & - & - & + & 5 & - & - \\
\hline 31 & Tringa ochropus Linnaeus, 1758 & - & - & - & - & - & - & - & 1 & - & - \\
\hline 32 & Scolopax rusticolus Linnaeus, 1758 & 3 & 1 & - & - & - & + & - & 4 & - & + \\
\hline 33 & Philomachus pugnax (Linnaeus, 1758) & 4 & - & - & - & - & - & - & 2 & - & - \\
\hline 34 & Calidris canutus (Linnaeus, 1758) & 2 & - & - & - & - & - & - & - & - & - \\
\hline 35 & Limicolae indet. & 6 & 2 & - & - & - & - & - & 2 & - & - \\
\hline 36 & Larus sp. & - & 1 & - & - & - & - & - & - & - & - \\
\hline 37 & Charadriiformes indet. & 1 & - & - & - & - & - & - & - & - & - \\
\hline 38 & Columba oenas Linnaeus, 1758 & - & - & - & - & - & + & - & - & - & - \\
\hline 39 & Cuculus canorus Linnaeus, 1758 & - & - & - & - & - & - & - & 1 & - & - \\
\hline 40 & Otus scops (Linnaeus, 1758) & - & - & - & - & - & - & - & 2 & - & - \\
\hline 41 & Strix aluco Linnaeus, 1758 & - & 1 & - & - & - & - & - & - & + & - \\
\hline 42 & Strix uralensis Pallas, 1771 & - & - & - & - & - & - & - & 2 & - & - \\
\hline 43 & Asio otus (Linnaeus, 1758) & - & - & - & - & - & - & + & - & - & - \\
\hline 44 & Asio flammeus (Pontoppidan, 1763) & - & 1 & - & - & - & - & - & - & - & - \\
\hline 45 & Asio sp. & - & 1 & - & - & - & - & - & - & - & - \\
\hline 46 & Aegolius funereus (Linnaeus, 1758) & 2 & 1 & - & - & - & - & - & 2 & - & - \\
\hline 47 & Dryocopus martius (Linnaeus, 1758) & - & - & - & - & - & - & - & 1 & - & - \\
\hline 48 & Dendrocopos minor (Linnaeus, 1758) & - & - & - & - & - & + & - & - & - & - \\
\hline 49 & Dendrocopos major (Linnaeus, 1758) & - & 1 & - & - & - & - & - & 12 & - & - \\
\hline 50 & Dendrocopos leucotos (Bechstein, 1802) & - & 1 & - & - & - & - & - & 1 & - & - \\
\hline 51 & Dendrocopos sp. & - & - & - & - & - & - & - & 3 & - & - \\
\hline 52 & Picoides tridactylus (Linnaeus, 1758) & - & - & - & - & - & - & - & 1 & - & - \\
\hline 53 & Melanocorypha yeltoniensis (J.R. Forster, 1768) & 1 & - & - & - & - & - & - & - & - & - \\
\hline 54 & Hirundo rustica Linnaeus, 1758 & 1 & - & - & - & - & - & - & 1 & - & - \\
\hline 55 & Delichon urbica (Linnaeus, 1758) & - & 1 & - & - & - & - & - & 1 & - & - \\
\hline 56 & Lanius excubitor Linnaeus, 1758 & - & - & - & - & - & - & - & 2 & - & - \\
\hline 57 & Bombycilla garrulus (Linnaeus, 1758) & - & 1 & - & - & - & - & - & - & - & - \\
\hline 58 & Luscinia luscinia (Linnaeus, 1758) & - & - & - & - & - & - & - & 1 & - & - \\
\hline 59 & Tarsiger cyanurus (Pallas, 1773) & - & - & - & - & - & - & - & 1 & - & - \\
\hline 60 & Turdus torquatus Linnaeus, 1758 & 3 & 1 & - & - & - & - & - & 1 & - & - \\
\hline 61 & Turdus pilaris Linnaeus, 1758 & 4 & 1 & - & - & - & - & + & 1 & - & + \\
\hline 62 & Turdus viscivorus Linnaeus, 1758 & 2 & 3 & - & - & - & + & - & 2 & + & - \\
\hline 63 & Turdus philomelos Brehm, 1831 & - & 1 & - & - & + & + & - & 2 & - & + \\
\hline 64 & Turdus sp. & 13 & 9 & - & - & - & - & - & 8 & - & - \\
\hline 65 & Sitta europaea Linnaeus, 1758 & - & - & - & - & - & - & - & 1 & - & - \\
\hline 66 & Carpodacus erythrinus (Pallas, 1770) & - & 1 & - & - & - & - & - & - & - & - \\
\hline 67 & Pyrrhula pyrrhula (Linnaeus, 1758) & - & - & - & - & - & - & - & 2 & - & - \\
\hline 68 & Coccothraustes coccothraustes (Linnaeus, 1758) & - & - & - & - & - & - & - & 1 & - & - \\
\hline 69 & Fringillidae indet. & - & 1 & - & - & - & - & - & - & - & - \\
\hline
\end{tabular}


Table 11 (continued)

\begin{tabular}{|c|c|c|c|c|c|c|c|c|c|c|c|}
\hline \multirow[t]{3}{*}{$\mathrm{N}$} & \multirow{3}{*}{$\begin{array}{l}\text { Stratigraphy } \\
\text { Taxa/Cave }\end{array}$} & \multirow{3}{*}{$\begin{array}{l}\text { Upper Neopleistocene } \\
\text { Kudashevo (MIS 2) } \\
\text { BT3(3) }\end{array}$} & \multicolumn{9}{|c|}{ Holocene (MIS 1) } \\
\hline & & & \multirow{2}{*}{$\begin{array}{l}\text { Lower-Middle } \\
\mathrm{BT}(2)\end{array}$} & \multicolumn{5}{|c|}{ Lower-Upper } & \multicolumn{3}{|l|}{ Upper } \\
\hline & & & & $\mathrm{V}(1)$ & $\mathrm{Z}(1)$ & $\mathrm{N}(1)$ & ST6(1) & ST10(1) & $\mathrm{BT}(1)$ & AG & L2a \\
\hline 70 & Garrulus glandarius (Linnaeus, 1758) & - & 4 & - & - & - & + & - & 8 & - & - \\
\hline 71 & Nucifraga caryocatactes (Linnaeus, 1758) & - & - & - & - & - & - & - & 2 & - & - \\
\hline 72 & Pica pica (Linnaeus, 1758) & 3 & 2 & - & - & - & + & - & 5 & - & - \\
\hline 73 & Corvus monedula (Linnaeus, 1758) & - & 1 & - & - & - & + & - & & - & - \\
\hline 74 & Corvus cornix (corone) (Linnaeus, 1758) & - & - & - & - & + & + & - & - & - & - \\
\hline 75 & Corvidae indet. & - & - & - & - & - & - & - & 2 & - & - \\
\hline 76 & Passeriformes indet. & 3 & 5 & - & - & - & - & - & 4 & - & - \\
\hline 77 & Aves indet. & 124 & 119 & - & - & - & - & - & 138 & - & - \\
\hline
\end{tabular}

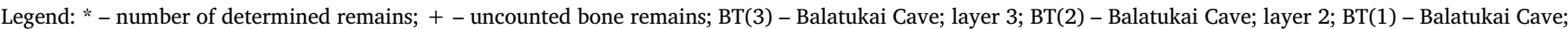

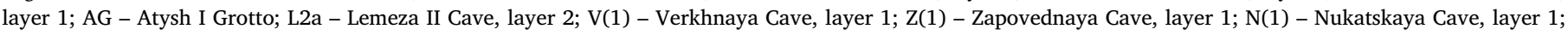
ST6(1) - Sikiyaz-Tamak 6 Cave, layer 1; ST10 (1) - Sikiyaz-Tamak 10 Cave, layer 1. MIS - Marine Isotope Stages.

1758), and Gobio gobio (Linnaeus, 1758)) were identified in the deposits assigned to the upper part of the Upper Neopleistocene and to the Holocene. The other species were only discovered in the Upper Neopleistocene deposits (Hucho taimen (Pallas, 1773), Salmo trutta Linnaeus, 1758, and Perca fluviatilis Linnaeus, 1758) or only in the Holocene deposits (Squalius cephalus (Linnaeus, 1758), Leuciscus idus (Linnaeus, 1758), and Leuciscus leuciscus (Linnaeus, 1758)). In sediments of different periods, the amount of bones varies significantly (Table 10).

All the fossil bone remains belong to modern freshwater species. A number of species (Hucho taimen Pallas, 1773, Salmo trutta Linnaeus, 1758, Thymallus thymallus (Linnaeus, 1758), Squalius cephalus (Linnaeus, 1758), Barbatula barbatula (Linnaeus, 1758), Cottus gobio Linnaeus, 1758) prefers fast flowing rivers. Most species inhabit the modern waters of Northern Asia and Europe and five species (Salmo trutta Linnaeus, 1758, Thymallus thymallus (Linnaeus, 1758), Squalius cephalus (Linnaeus, 1758), Barbatula barbatula (Linnaeus, 1758), Cottus gobio Linnaeus, 1758) inhabit only European rivers (Reshetnikov, 1998). There are no thermophilic species in the ichthyofauna. All the identified fish species were also discovered in the Middle Neopleistocene, Upper Neopleistocene and Holocene localities of Europe (Lebedev, 1960).

\subsection{Herpetology}

\subsubsection{Amphibians}

The Late Pleistocene and Holocene amphibian data from caves in the mountainous part of the Southern Urals allow us to characterize the amphibian communities of the Kudashevo Horizon and the Holocene time intervals. During end of the Kudashevo time until the Late Holocene, species that prefer forest habitats - Bufo bufo (Linnaeus, 1758), Rana arvalis Nilsson, 1842 and Rana temporaria Linnaeus, 1758 dominated. These faunas contain also warm-loving species such as Bufo viridis Laurenti, 1768 (Middle Holocene) which prefer open steppe habitats as well as Triturus cristatus (Laurenti, 1768) and Bombina sp. (Late Holocene) - inhabitants of the broad-leaved forests.

\subsubsection{Reptiles}

The Late Pleistocene and Holocene reptile data from caves in the mountainous part of the Southern Urals characterize the communities of the Kudashevo Horizon and the Lower, Middle and Upper Holocene. Starting from the end of the Kudashevo time interval until recent time, there were in the reptilian faunas species living in open habitats (meadow and steppe biotopes) - Lacerta agilis Linnaeus, 1758 and Vipera ursinii (Bonaparte, 1835), as well as species that occur in forest and near-water habitats - Anguis fragilis Linnaeus, 1758, Zootoca vivipara (Lichtenstein, 1823), Coronella austriaca Laurenti, 1768, Natrix natrix (Linnaeus, 1758) and Vipera berus (Linnaeus, 1758). In the faunas there were single species represented by Eremias cf. arguta (Pallas, 1773) (Middle Holocene), Elaphe cf. dione (Pallas, 1773) (end of Kudashevo time and Middle Holocene), and Natrix tessellata (Laurenti, 1768) (Late Holocene) which prefer warm and dry habitats.

The eastern margin of the Eastern-European Plain is, in contrast to the rest of Eastern Europe, herpetologically insufficiently studied. Several localities in the middle reaches of the Volga River are known to contain Late Pleistocene and Holocene reptiles and amphibians: Bolshie Tigany, Krasnyi Bor, Domashkinskie Vershiny, Strelnenskaya cave and Vovanova cave (Ratnikov, 2002, 2009; Yakovlev et al., 2013, b; Yakovleva et al., 2014). The species composition of the herpetofauna from these localities is similar to that of the studied sites from the mountainous part of the Southern Urals, but in the Volga River faunal associations, species of open biotopes prevail.

\subsection{Ornithology}

Remains of birds are only found in deposits of the younger part of the Upper Neopleistocene (MIS 2) and in Holocene (MIS 1). The endLate Neopleistocene fauna includes species that occur near water bodies, inhabit open and semi-open landscapes and closed and semiclosed landscapes. The dominant species is Lagopus lagopus (Linnaeus, 1758) which inhabits open landscapes. The species composition shows that at the end of the Late Neopleistocene open landscapes dominated in the Southern Urals; however, also closed and semi-closed landscapes covered large areas.

Species of the Holocene avifauna belong to the same landscapebiotope groups as the Late Pleistocene species: species living near water bodies, in open and semi-open landscapes and in closed and semi-closed landscapes. An increase in the number of species during the Holocene was due an increase of closed and semi-closed biotopes. Species that inhabit forest appeared (Dryocopus martius (Linnaeus, 1758), D. minor (Linnaeus, 1758), D. major (Linnaeus, 1758), D. leucotos (Bechstein, 1802), and Picoides tridactylus (Linnaeus, 1758)) in the Southern Urals Holocene avifauna assemblage which is due to a significant increase of areas with a forest vegetation. All the recorded Holocene species occur currently the Southern Urals.

\subsection{Mammalogy}

\subsubsection{Small mammals}

The central part of the Southern Urals mountains

During the beginning of the Late Pleistocene (Kushnarenkovo time, MIS 5; Idrisovo, Ignatievskaya caves) Microtus gregalis (Pallas, 1779) dominated (see Table 12) whereas other species, for example Cricetulus migratorius (Pallas, 1773), Apodemus uralensis (Pallas, 1811) and Myopus schisticolor (Lilljeborg, 1844) were rare. The fauna from the Kushnarenkovo deposits is a non-analogue fauna occurring under moderate 


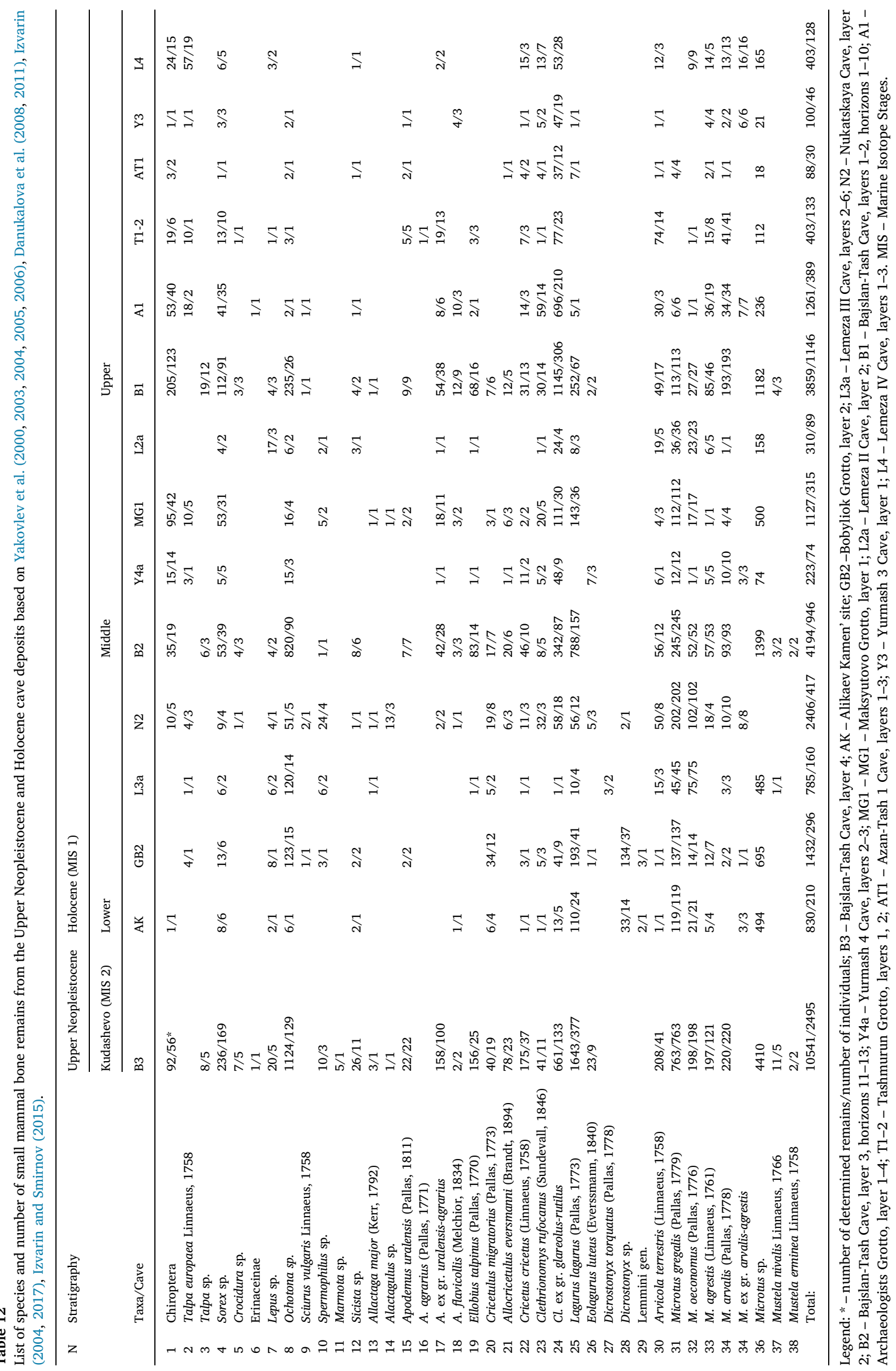




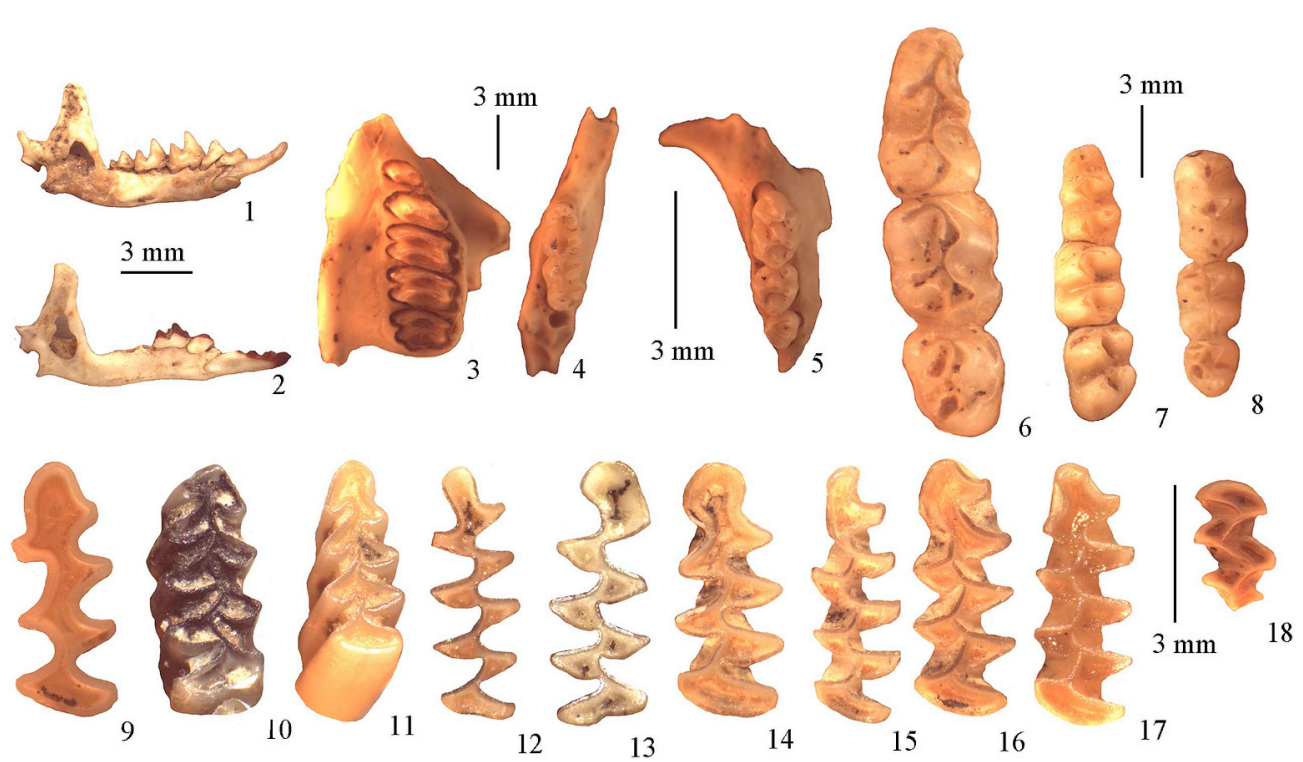

Fig. 6. Key-species of small mammals found in the Upper Pleistocene (Kudashevo Horizon) unconsolidated deposits of the Bajslan-Tash Cave, Southern-Urals region, Russia.

Legend: 1 - Crocidura sp., right mandibula; 2 - Sorex sp., right mandibula; 3 - Ochotona sp., fragment of maxilla; 4 - Sicista sp., fragment of mandibula; 5 - Apodemus uralensis (Pallas, 1811), fragment of maxilla; 6 - Cricetus cricetus (Linnaeus, 1758), m1-m3; 7 - Allocricetulus eversmanni (Brandt, 1894), $\mathrm{m} 1-\mathrm{m} 3 ; 8$ - Cricetulus migratorius (Pallas, 1773), M1-M3; 9 - Ellobius talpinus (Pallas, 1770), $\mathrm{m} 1 ; 10$ - Clethrionomys rufocanus (Sundevall, 1846), m1; 11 - Clethrionomys ex gr. glareolus-rutilus, m1; 12 - Lagurus lagurus (Pallas, 1773), m1; 13 - Eolagurus luteus (Everssmann, 1840); 14 - Arvicola terrestris (Linnaeus, 1758), $\mathrm{m} 1 ; 15$ - Microtus gregalis (Pallas, 1779), m1; 16 - Microtus oeconomus (Pallas, 1776), m1; 17 - Microtus arvalis (Pallas, 1778), m1; 18 - Microtus agrestis (Linnaeus, 1761), M2. 1, 2 - lateral view; 3-18 - top view. climatic conditions.

During the Tabulda time interval (MIS 3; Idrisovo and Ignatievskaya caves) Microtus gregalis (Pallas, 1779) and M. oeconomus (Pallas, 1776) formed the main part in the small-mammal associations (see Table 12) whereas Apodemus flavicollis (Melchior, 1834) and Cricetus cricetus (Linnaeus, 1758) were very rare.

The small-mammal fauna from the Kudashevo Horizon (MIS 2; Prizhim Grotto, Ignatievskaya, Serpievskaya 1 and 2 caves) reflects cold climatic conditions; Eolagurus luteus (Everssmann, 1840) Allactaga major (Kerr, 1792), Lagurus lagurus (Pallas, 1773) and Dicrostonyx guilielmi Sanford, 1870 are common. In the central part of the Southern Urals the Late Neopleistocene small mammal fauna was periglacial, both in the warm and cold periods. At the end of the Kudashevo time interval lemmings did not occur in southern part of the Southern Urals (Bajslan-Tash cave in the valley of the Belaya River); the fauna was composed of steppe and semi-desert species (Table 12).

Upper Holocene deposits were recorded in the Sim River valley (Sim I, II and III Grottoes; Serpievskaya 1 cave). During the Upper Holocene Microtus arvalis (Pallas, 1778), Microtus agrestis (Linnaeus, 1761), Arvicola terrestris (Linnaeus, 1758), Clethrionomys rutilus (Pallas, 1779), were numerous and Apodemus flavicollis (Melchior, 1834), Eliomys quercinus (Linnaeus, 1766), Microtus gregalis (Pallas, 1779) and Lagurus lagurus (Pallas, 1773) were rare (Table 12). The fauna is similar to the small mammal fauna from the Lemeza River valley. Upper Holocene small mammal assemblages from the Belaya River valley contain a larger part of steppe species.

\section{The Southern Trans-Urals}

The small mammal fauna from the Kudashevo Horizon (Syrtinskaya and Smelovskaya 2 caves) contains predominant species such as Lagurus lagurus (Pallas, 1773), Eolagurus luteus (Everssmann, 1840) and Microtus gregalis (Pallas, 1779) whereas in the Lower Holocene deposits (Alekseevskaya, Chernyshevskaya V and Syrtinskaya caves) Microtus gregalis (Pallas, 1779), Lagurus lagurus (Pallas, 1773) and Ellobius talpinus (Pallas, 1770) are most numerous (Table 12).

The Middle Holocene deposits in the Alekseevskaya and Syrtinskaya caves yieled numerous remains of Microtus gregalis (Pallas, 1779) and Lagurus lagurus (Pallas, 1773) and less numerous Microtus ex gr. arvalis (Pallas, 1778) and Ellobius talpinus (Pallas, 1770) (Table 12).

During Late Holocene (Syrtinskaya, Khudolaz, Alekseevskaya and Chernorechka caves) Microtus gregalis (Pallas, 1779), M. ex gr. arvalis (Pallas, 1778) dominated and Ellobius talpinus (Pallas, 1770), Lagurus lagurus (Pallas, 1773) and Arvicola terrestris (Linnaeus, 1758) were common.

The small mammal species composition of the Trans-Urals area changed unsignificantly - Eolagurus luteus (Everssmann, 1840) and Alactagulus pumilio (Kerr, 1790) disappeared during the Late Holocene. The Trans-Urals small-mammal fauna in general is represented by species that prefer to inhabit steppe biotopes (Smirnov and Kuzmina, 2001).

Late Pleistocene and Holocene small-mammal faunas from the Southern Trans-Urals are most similar to the contemporaneous faunas from the Southern part of the Southern Urals (The Belaya River valley), in which the proportion of forest and near-water habitats is larger.

\subsubsection{Large mammals}

\section{The central part of the Southern Urals mountains}

The large mammal fauna from cave sediments of almost all the stratigraphical units exposed in the central part of the Southern Urals and dated to the end of the Middle Pleistocene (Elovka Horizon, MIS 6?) to the Upper Holocene (MIS 1) (Tables 13 and 14) were investigated.

Species that inhabit open landscapes (Marmota bobak (Müller, 1776), Vulpes lagopus (Linnaeus, 1758), Ursus spelaeus Rosenmüller, 1794, U. savini Andrews, 1922, Mustela eversmanni (Lesson, 1827), Equus ferus Boddaert, 1785, Coelodonta antiquitatis (Blumenbach, 1799), Rangifer tarandus (Linnaeus, 1758), and Bison priscus Bojanus, 1827) and intrazonal species (Lepus timidus Linnaeus, 1758, Canis lupus Linnaeus, 1758, V. vulpes Linnaeus, 1758, Mustela erminea Linnaeus, 1758, M. nivalis Linnaeus, 1766, and Gulo gulo (Linnaeus, 1758)) are most numerous in the faunas of the end of the Middle Pleistocene. There are very few species associated with tree-shrub vegetation (Martes sp., Stephanorhinus cf. kirchbergensis (Jäger, 1839), Cervus elaphus Linnaeus, 1758). The fauna indicates the dominance of the open landscapes with a small amount of trees and shrubs.

At the beginning of the Late Pleistocene (Kushnarenkovo, MIS 5e), open landscape species continue to dominate (Marmota bobak (Müller, 1776), Vulpes lagopus (Linnaeus, 1758), Ursus savini Andrews, 1922, U. spelaeus Rosenmüller, 1794, M. eversmannii (Lesson, 1827), Equus ferus Boddaert, 1785, Coelodonta antiquitatis Blumenbach, 1799, Rangifer tarandus (Linnaeus, 1758), Bison priscus Bojanus, 1827, Saiga tatarica (Linnaeus, 1766), and Ovis ammon Linnaeus, 1758), but there were more species associated with trees and shrubs (Hystrix brachyura 

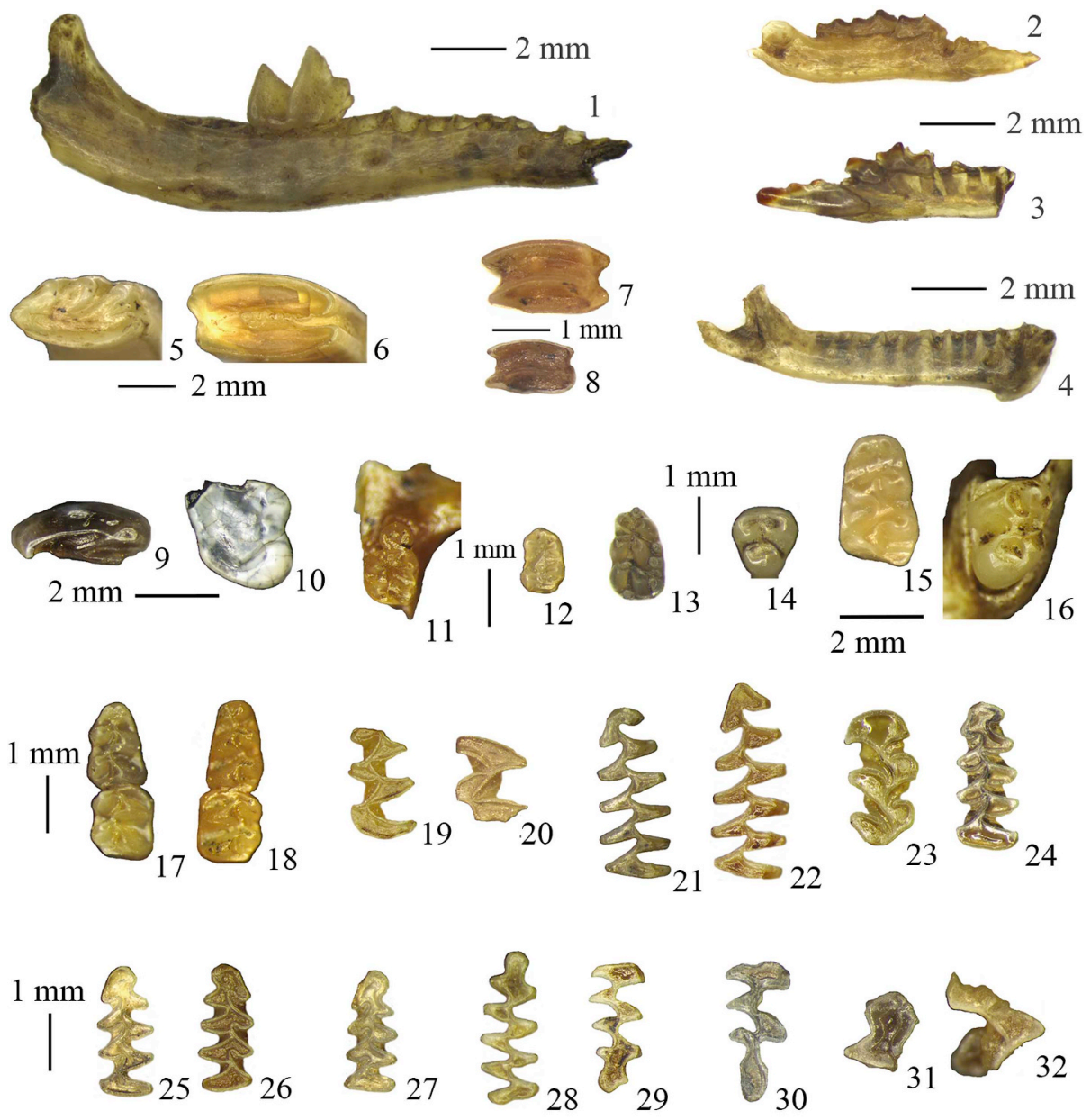

Fig. 7. Key-species of small mammals found in the early-Holocene sediments of Grotto Bobyliok and Alikaev Kamen' site, Southern Fore-Urals region, Russia.

Legend: 1 - Talpa europaea Linnaeus, 1758: descending branch of dexter mandibula with $\mathrm{m} 2 ; 2-3-$ Sorex sp.: descending branch of dexter mandibula with i1 and m1-m3; fragment of descending branch of sinister mandibula with i1, p4 and m1; 4 Chiroptera: descending branch of dexter mandibula without teeth; 5-6 - Lepus sp.: P2 dexter; dexter upper tooth; 7-8 - Ochotona sp.: upper sinister teeth P4-M2; 9 - Spermophilus sp.: fragment of M1 dexter; 10 - Sciurus vulgaris Linnaeus, 1758: m3 dexter; 11-12 - Sicista sp.: fragment of sinister maxilla with P4 and M1; m1 sinister; 13 - Apodemus uralensis (Pallas, 1811): $\mathrm{m} 1$ dexter; 14 - A. cf. flavicollis (Melchior, 1834): m3 dexter; 15-16 - Cricetus cricetus (Linnaeus, 1758): $\mathrm{m} 1$ sinister; fragment of sinister mandibula with $\mathrm{m} 3$; 17-18 - Cricetulus migratorius (Pallas, 1773): $\mathrm{m} 1$ and $\mathrm{m} 2$ dexter; $\mathrm{m} 1$ and m2 sinister; 19-20 - Lemmini gen.: m2 sinister; fragment of sinister $\mathrm{m} 1$ or $\mathrm{m} 2 ; 21-22$ - Dicrostonyx sp.: m1 sinister; 23-24 - Clethrionomys rufocanus (Sundevall, 1846): M1 dexter; m1 sinister; 25-26 Cl. glareolus (Schreber, 1780): $\mathrm{m} 1$ sinister; $\mathrm{m} 1$ dexter; 27 - Cl. rutilus (Pallas, 1779): $\mathrm{m} 1$ sinister; 28-29 - Lagurus lagurus (Pallas, 1773): m1 dexter; M3 dexter; 30. Eolagurus luteus (Eversmann, 1840): M3 dexter; 31-32 - Arvicola terrestris (Linnaeus, 1758): fragment of sinister $\mathrm{m} 1$; fragment of sinister M2; 33-34 - Microtus gregalis (Pallas, 1779): $\mathrm{m} 1$ sinister; 35-36 - M. oeconomus (Pallas, 1776): $\mathrm{m} 1$ dexter; 37-39 - M. agrestis Linnaeus, 1761: M2 dexter; M2 sinister; fragment of sinister $\mathrm{m} 1 ; 40-M$. arvalis s.l.: $\mathrm{m} 1$ dexter. Grotto Bobyliok, layer 2 (1, 3, $5,7,9,10,12,13,15,17,20,21,24,25,27,29-31$, 33, 36, 38-40) and Alikaev Kamen' site (2, 4, 6, 8, $11,14,16,18,19,22,23,26,28,32,34,35,37)$.
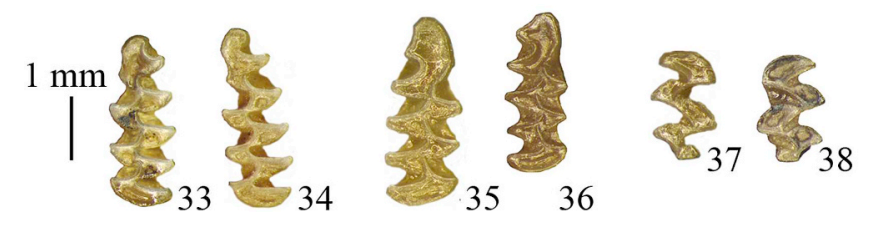

Linnaeus, 1758, Dryomys nitedula (Pallas, 1778), Ursus arctos Linnaeus, 1758, Martes sp., Stephanorhinus cf. kirchbergensis Jäger, 1839, and Cervus elaphus Linnaeus, 1758). In addition, typical forest species (Sciurus vulgaris Linnaeus, 1758, Apodemus flavicollis (Melchior, 1834), and Lynx lynx Linnaeus, 1758) were part of the fauna. It should be noted that the fauna includes "thermophilic" species characteristic of interglacials: Hystrix brachyuran Linnaeus, 1758, Dryomys nitedula (Pallas, 1778), Meles meles (Linnaeus, 1758). In the composition of taphonomically mixed bone remains from the Imanai cave (Kushnarenkovo-Kudashevo, MIS $5 \mathrm{e}-2$ ), the Asiatic black bear (Ursus thibetanus (G. Cuvier, 1823) and the wild boar (Sus scrofa Linnaeus, 1758) occur. They were part of the central Southern Urals fauna during the Kushnarenkovo period when open landscapes with large forests were wide-spread in the mountainous part of the Southern Urals.

The larger mammal fauna of the Saigatka horizon (MIS 4) is unknown so far.

The Tabulda fauna (MIS 3) lacks the Merck rhinoceros (Stephanorhinus cf. kirchbergensis Jäger, 1839), characteristic of the Middle and early Late Pleistocene, and there are no "thermophilic" species such as Hystrix brachyura Linnaeus, 1758, Dryomys nitedula (Pallas, 1778), and Meles meles (Linnaeus, 1758). The fauna includes open landscape species: Marmota bobak (Müller, 1776), Vulpes lagopus
(Linnaeus, 1758), V. corsac Linnaeus, 1768, Ursus spelaeus Rosenmüller, 1794, M. eversmannii Lesson, 1827, Equus ferus Boddaert, 1785, Coelodonta antiquitatis (Blumenbach, 1799), Rangifer tarandus (Linnaeus, 1758), Bison priscus Bojanus, 1827, Saiga tatarica (Linnaeus, 1766), and Ovis ammon (Linnaeus, 1758) (Table 13).

There are few species that are associated with tree-shrub vegetation (Cuon alpinus (Pallas, 1811), Ursus arctos Linnaeus, 1758, Martes zibellina (Linnaeus, 1758), Lynx lynx (Linnaeus, 1758), and Cervus elaphus Linnaeus, 1758). By the end of this period, cave bears (Ursus spelaeus Rosenmüller, 1794), cave hyena (Crocuta crocuta spelaea Goldfuss, 1823), dhole (Cuon alpinus (Pallas, 1811) and mufflon (Ovis ammon (Linnaeus, 1758)) disappeared from the fauna.

Open landscapes with small tracts of forest vegetation dominated during the Tabulda time interval. At the end of the Late Pleistocene (Kudashevo, MIS 2), open landscape and intrazonal species still dominated (Table 13). This indicates the predominance of open landscapes and limited distribution of forest vegetation.

At the beginning of the Holocene, changes occur in the fauna - for the first time a roe deer (Capreolus pygargus (Pallas, 1771)) appears, which was absent in the Pleistocene faunas (Tables 13 and 14). Open landscape species (Marmota bobak (Müller, 1776), Vulpes lagopus (Linnaeus, 1758), V. corsac (Linnaeus, 1768), Mustela eversmannii (Lesson, 


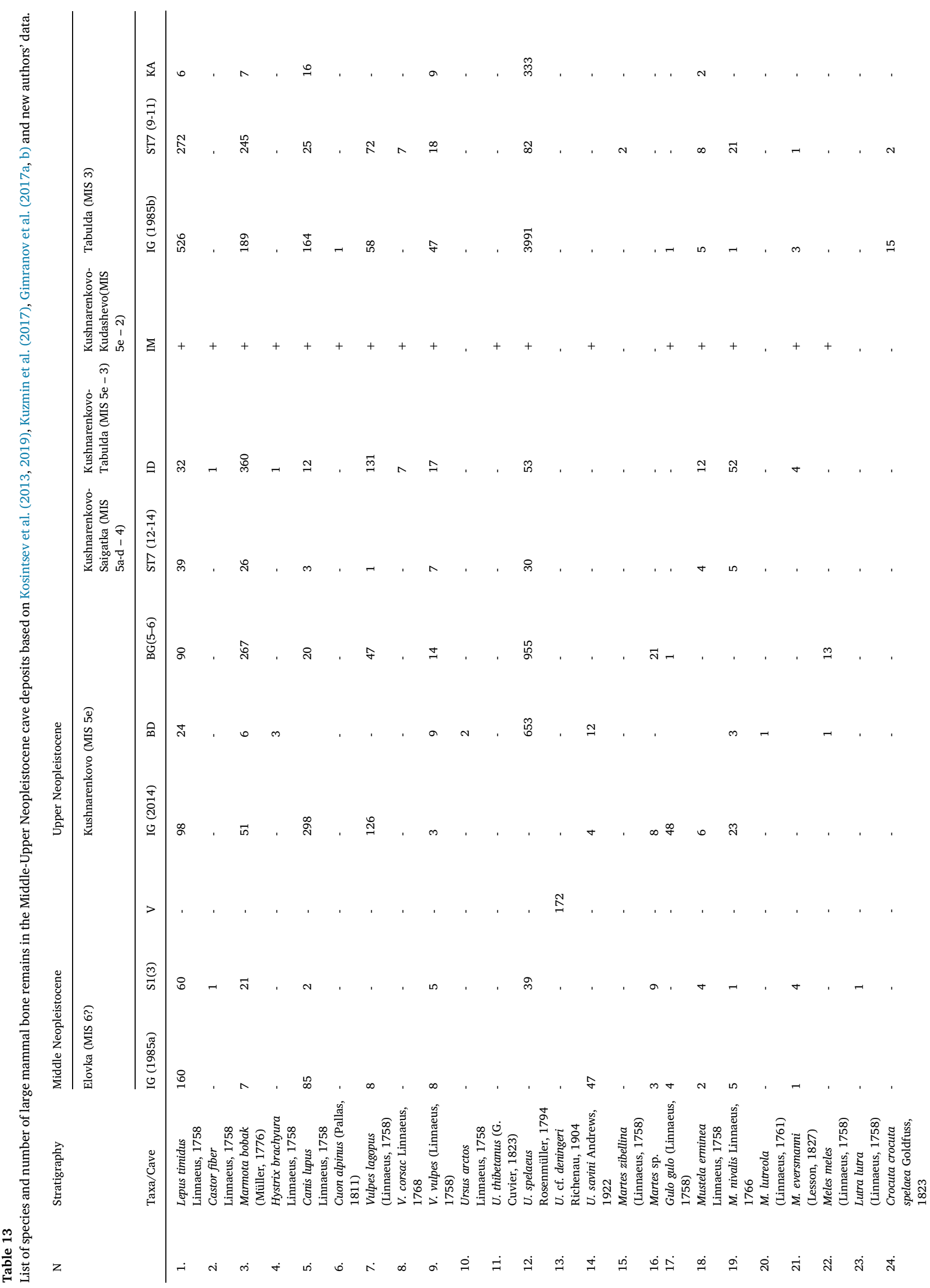




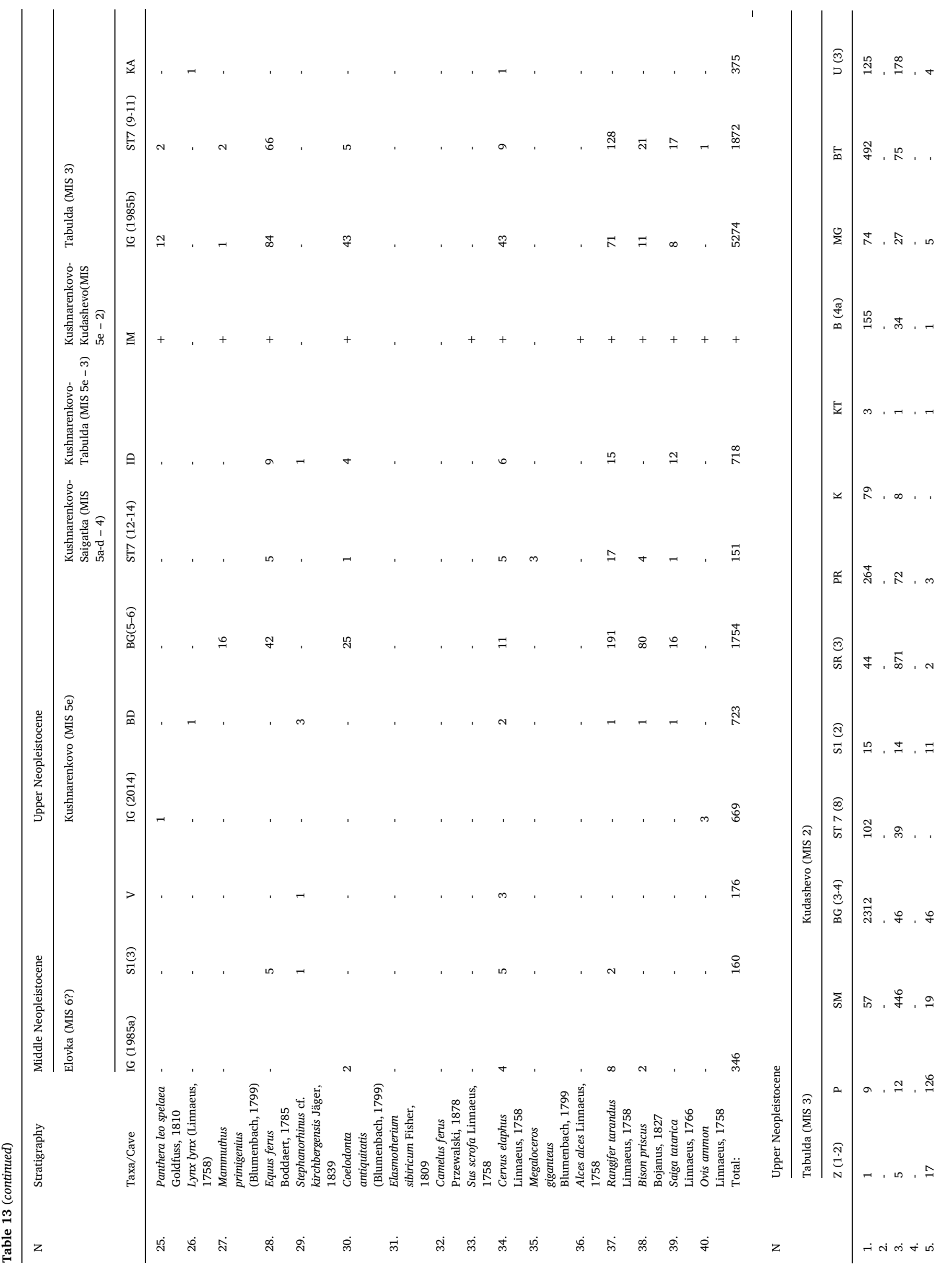




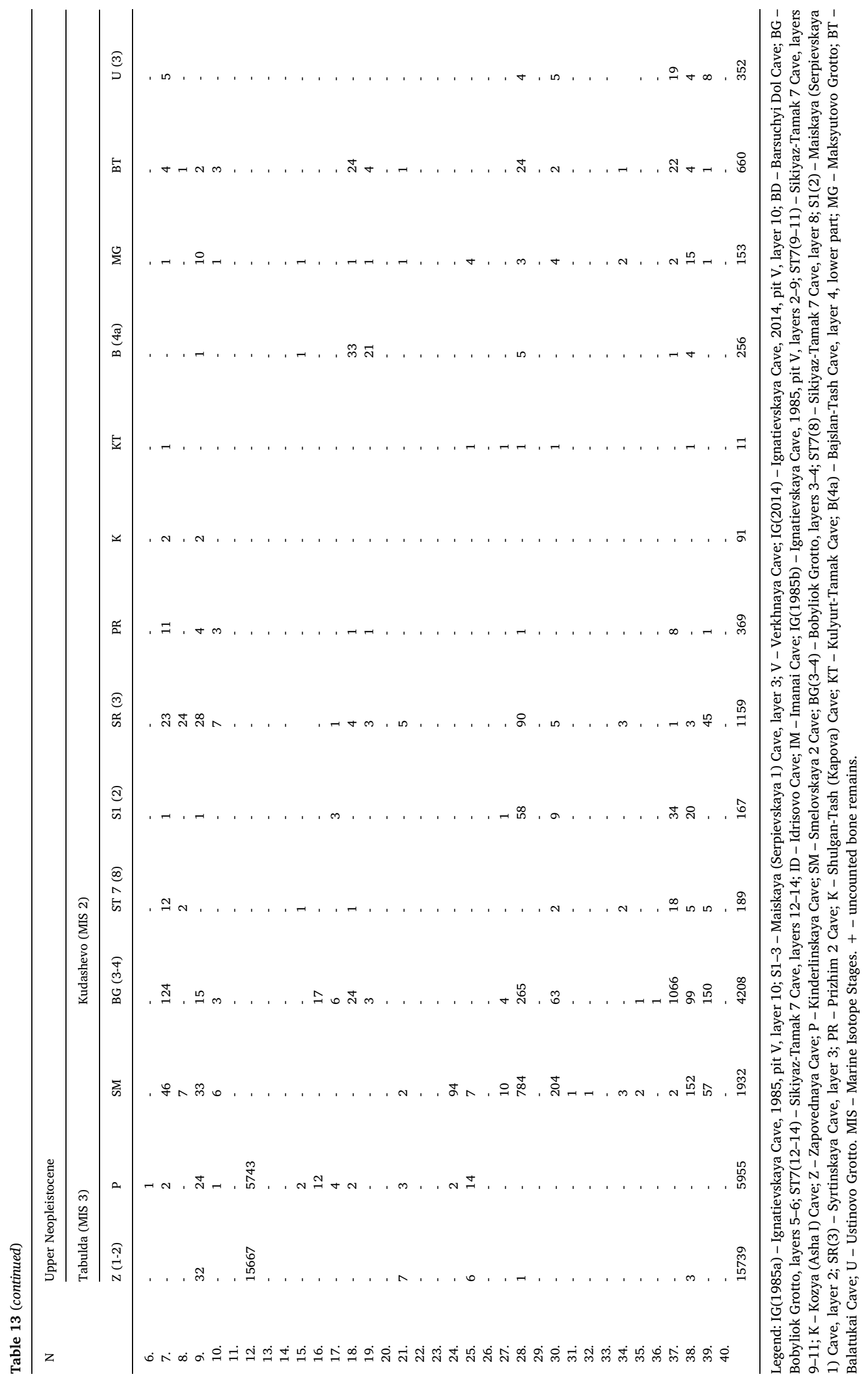


1827), Equus ferus Boddaert, 1785, Rangifer tarandus (Linnaeus, 1758), Bison priscus Bojanus, 1827, and Saiga tatarica (Linnaeus, 1766)) are still numerous (Table 14). At the beginning of the Holocene, open landscapes continue to occupy large areas in the central part of the Southern Urals Mountains, but there was an increase in the areas of semi-open landscapes.

During the Middle Holocene, the number of open landscape species was decreasing - Vulpes lagopus (Linnaeus, 1758), V. corsac (Linnaeus, 1768), Mustela eversmannii Lesson, 1827, and Rangifer tarandus (Linnaeus, 1758) disappeared. The fauna includes Castor fiber Linnaeus, 1758, Lutra lutra (Linnaeus, 1758), Meles meles (Linnaeus, 1758), Sus scrofa Linnaeus, 1758, which were absent in the fauna from the Tabulda (MIS 3) and Kudashevo (MIS 2) time intervals. The number of bone remains of $V$. vulpes (Linnaeus, 1758), Ursus arctos Linnaeus, 1758, Martes sp., Capreolus pygargus (Pallas 1771), and Alces alces (Linnaeus, 1758) (Table 14) highly increased. At the end of the Middle Holocene (end of Subboreal) domestic ungulates (Equus caballus Linnaeus, 1758, Ovis aries Linnaeus, 1758) appeared. During the Middle Holocene, forest landscapes begin to dominate, but open landscapes still occupy relatively large areas.

During the Upper Holocene, the Marmota bobak (Müller, 1776) and Mustela eversmannii Lesson, 1827 remain in the fauna, but the number of their remains significantly reduced. Forest and semi-open landscape species were dominant and open landscapes occupy small areas, probably located on the top of the mountains.

\section{The Southern Trans-Urals}

The large mammal fauna from the unconsolidated sediments of the three caves in the Southern Trans-Urals (Smelovskaya 2 Cave, Ustinovo Grotto (Table 13) and Alekseevskaya Cave) (Table 14) include during the Tabulda time interval (MIS 3) a. o. Elasmotherium sibiricum J. Fisher, 1809 and Camelus ferus Przewalski, 1878; species that did not occur in the fauna of the central part of the Southern Urals Mountains (Table 13). Their occurrence indicates the almost complete absence of forest vegetation in this area. The fauna of the late Late Pleistocene (Kudashevo, MIS 2) and the Early Holocene (MIS 1) lacks species that are associated with tree-shrub vegetation (Tables 13 and 14). Open landscapes are still preserved in the Southern Trans-Urals.

\section{Conclusions}

The area of the Southern Urals is characterized by a wide distribution of the Proterozoic and Palaeozoic carbonate rocks which contain numerous big and small caves; the result of karst process related to the humid and temperate climate conditions in the region. Series of unconsolidated deposits with a thickness ranging from 0.5 to $5 \mathrm{~m}$ were formed in these caves.

Investigations of the unconsolidated the Late Neopleistocene and Holocene cave deposits resulted in detailed biostratigraphical and palaeoenvironmental data (Fig. 8). The data indicate that the Southern Urals landscapes have a mosaic character. Due to the relief in a limited area, various plant communities (coniferous, deciduous, small-leaved and mixed forests, meadow, steppe and vegetation of the rocky slopes) occur. The forest vegetation, in turn, has unique regional features related to the fact that it was formed at the transition of Eastern European broadleaved, southern dark coniferous taiga and South-Uralian light coniferous forests. The modern mountain mixed forests of the Southern Urals appeared only during the latest Holocene. The forest-steppes were in general widespread during the Late Neopleistocene - Holocene. Forest vegetation occurred at higher altitudes during the warm periods (Tabulda, Middle-Late Holocene); forested areas reduced during the cold intervals (Kudashevo, Early Holocene). However, it should be noted that even during the coldest periods refugia of broad-leaved flora existed in the territory of the Southern Urals.

The late Neopleistocene and Holocene mollusc species are Holarctic species that occur in different ecological biotopes such as forest-steppe, forest and intrazonal (river banks) areas.
The Late Pleistocene and Holocene amphibian associations found in caves of the Southern Urals are characterized by species that prefer forest biotopes. The reptile faunas contain more species which inhabited open areas. This difference is related to the ecological features of the Amphibians which prefer biotopes with constant humidity and of the Reptiles which inhabit opened dry and warm areas on the hill slopes as well as meadows and even in forest biotopes.

The Pleistocene and Holocene fish fauna found in the caves of the Southern Urals is a characteristic freshwater fauna occurring in a temperate zone. All species currently inhabit the rivers of Europe. The ichthyofauna of the Southern Urals during the Late Pleistocene and Holocene did not show significant differences.

The Pleistocene and Holocene bird faunas found in the cave sediments of the Southern Urals included species that occur in the modern ornithological faunas of Northern Asia, Central and Northern Europe. The Late Pleistocene fauna was dominated by species that inhabit open and semi-open landscapes whereas, during the Holocene, species that prefer closed biotopes dominated the bird fauna indicating a change in the landscape during the Holocene. All Late Pleistocene and Holocene bird species still occur in the modern fauna of the Southern Urals.

The small-mammal data from the Late Pleistocene and Holocene cave deposits in the Southern Urals can be used, in association with other biostratigraphical data, to date the cave deposits from the late Glacial (Kudashevo interval) to the Early, Middle and Late Holocene. During the Late Pleistocene and Early Holocene disharmonious/nonanalogue faunas of the small mammals existed in the central and northern parts of the Southern Urals (Ufimian Plateau, Sim and Lemeza River valleys). These faunas included steppe, semi-desert species and rare lemmings. In the southern part of the Southern Urals and TransUrals, lemmings were absent. In the Southern Urals, starting from the Middle Holocene, there was gradual change of small-mammal communities with predominance of steppe species to predominance of forest species, and only in the Trans-Urals the steppe small-mammal fauna preserved. Modern small-mammal faunas appeared in the latitudinal section of the Belaya River valley at the end of the Late Holocene.

There were relatively little changes in the large-mammal fauna in the Southern Urals at the end of the Late Neopleistocene - beginning of Holocene. The relict population of Don hare (Lepus tanaiticus Gureev, 1964) was living in the Southern Urals during the Early Holocene. The large-mammal fauna during the end of the Late Neopleistocene and Early Holocene consisted of eurybiotic species and species of the open landscapes. Species that preferred forest landscapes, appeared at the end of the Early Holocene - beginning of the Middle Holocene. Modern species of the large-mammal fauna appeared in the second half of the Late Holocene.

\section{Data availability}

The palaeontological collections (molluscs and vertebrates) are kept at the Institute of Geology UFRC RAS (Ufa, Russian Federation) and Institute of Plant and Animal Ecology of UB RAS (Ekaterinburg, Russian Federation).

\section{Declaration of competing interest}

There are no conflict of interests in our manuscript.

\section{Acknowledgements}

The studies of the cave deposits were done in cooperation with the archaeologists Dr. V. Kotov, Dr. M. Rumyantcev, Dr. V. Yurin. The authors would like to thank them for their assistance. This work was achieved thanks to Russian State program N-0246-2019-0118 and was supported partly by RFBR, research projects No. 18-04-00982a, 18-34- 


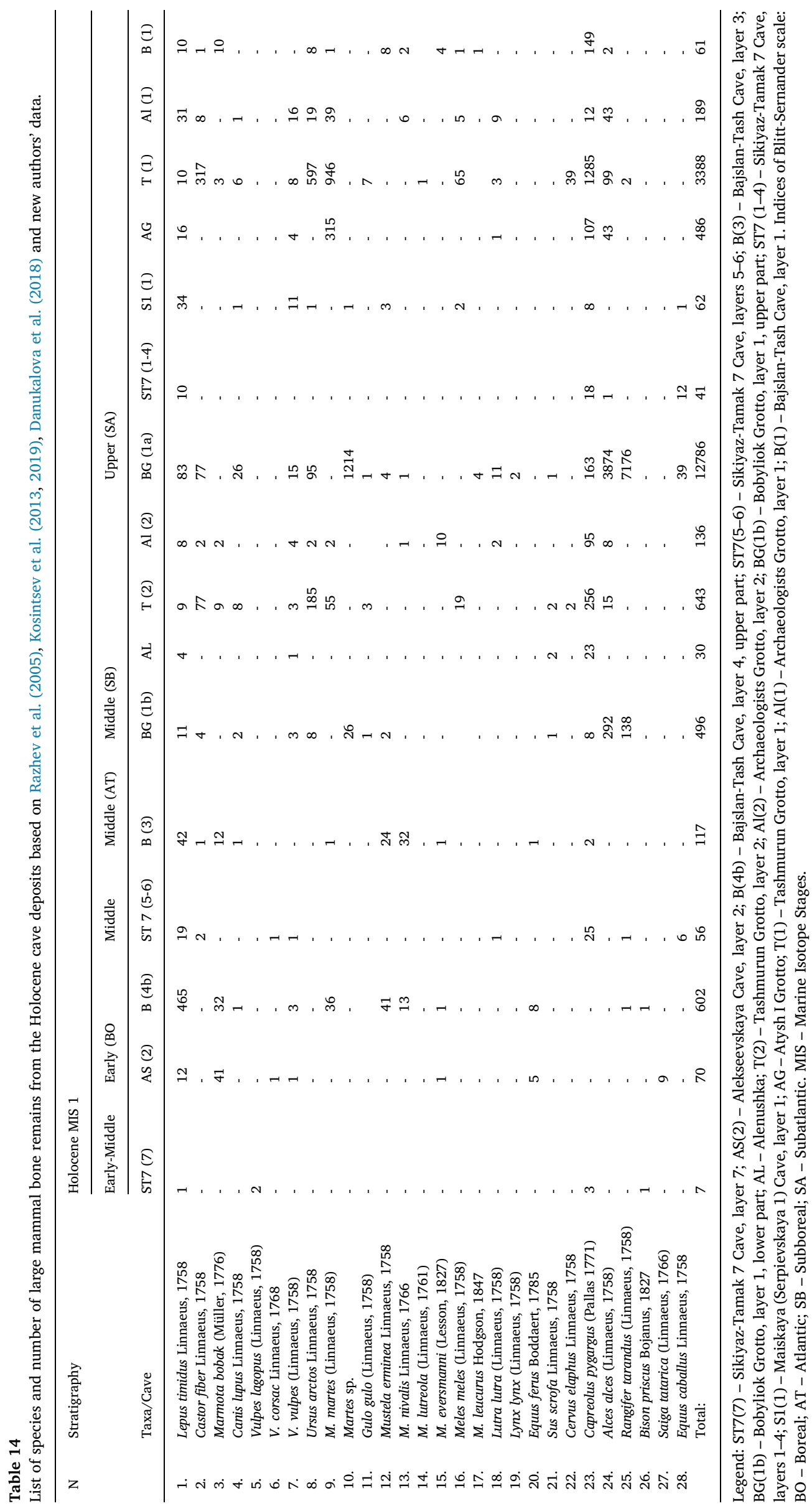




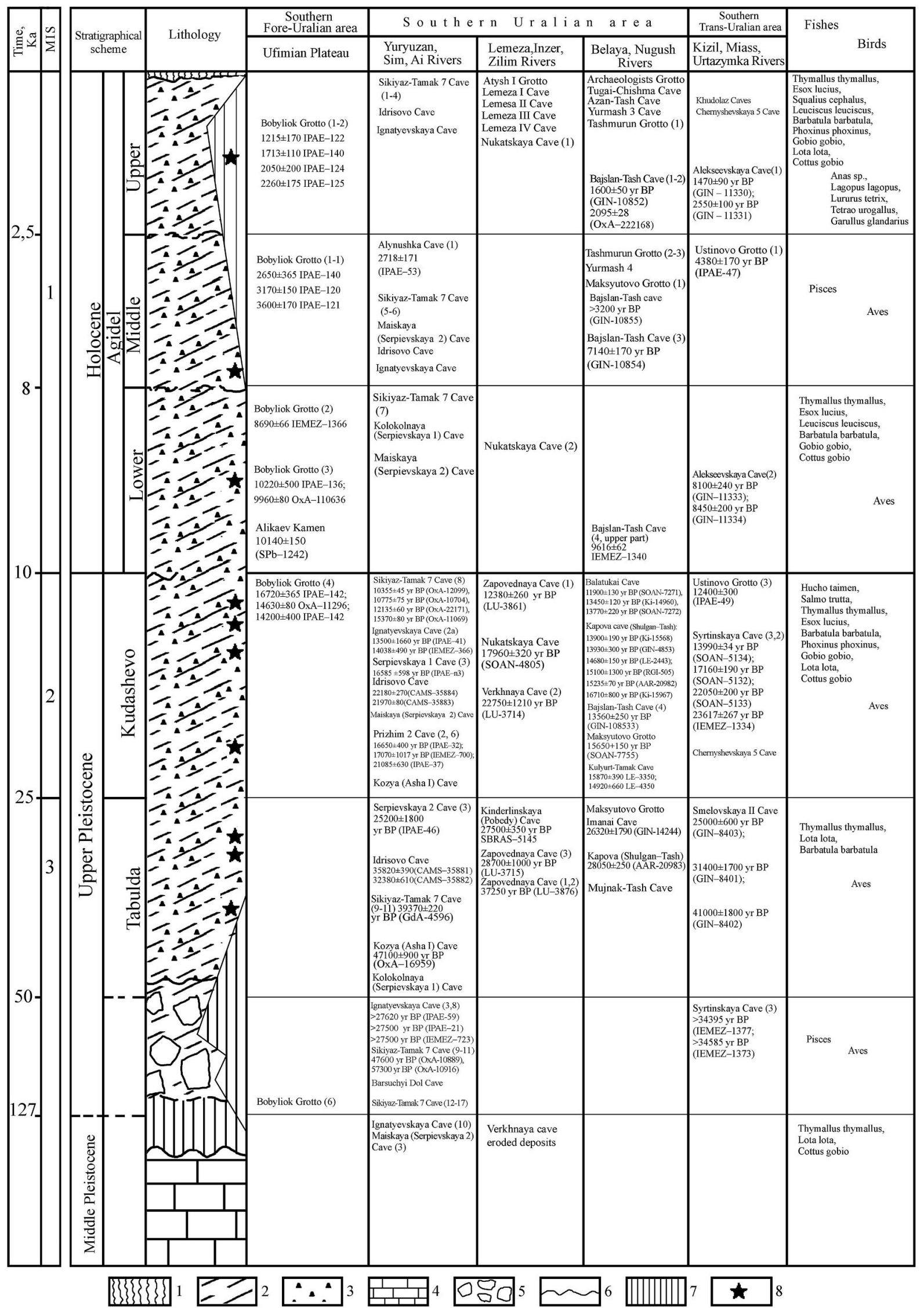

Fig. 8. Summarizing figure with stratigraphical units and the correlation of the different faunal and floral complexes.

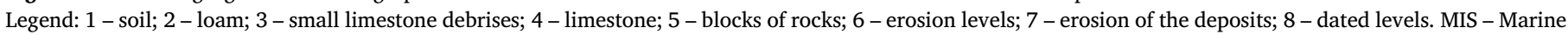
Isotope Stages. A tentative correlation between MIS and other data is shown. 


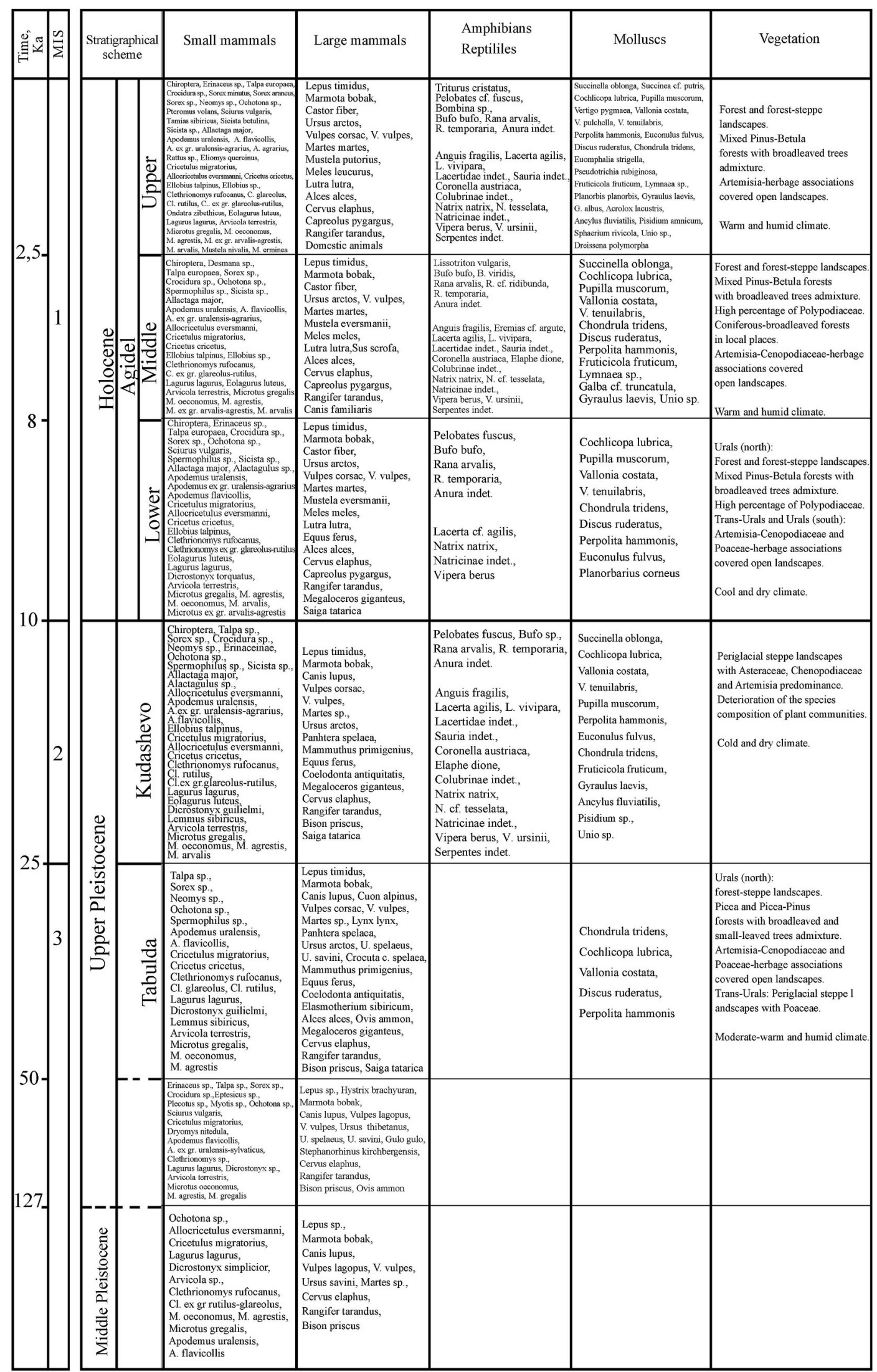

Zapovednaya (1-2) - cave name and number of layers in brackets

Fig. 8. (continued) 
00270mol_a (Russian Federation) A and Russian Goverement Program of Competitive Growth of Kazan Federal University. This paper deals with Quaternary key-sites of the Southern Fore-Urals and Southern Urals region in the frame of the DATESTRA (Database of Terrestrial European Stratigraphy) project (grant INQUA-SACCOM: 1612F). This paper mentioned objects of two geoparks: Idrisovo Cave is located on the territory of the "Yangan-Tau" Geopark, the first Russian geopark under umbrella of the Global Geoparks Nework UNESCO; Kinderlinskaya Cave - on the territory of the "Toratau" Geopark.

The authors also want to thank the Guest Editors of the Special Issue and the reviewers for their comments and suggestions and editors and the editorial board of Quaternary International for their patience and support.

\section{References}

Abdrakhmanov, R.F., Martin, V.I., Popov, V.G., Rozhdestvensky, A.P., Smirnov, A.I., Travkin, A.I., 2002. Karst Bashkortostana [Karst of Bashkortostan]. Informreclama Press, Ufa, pp. 1-384 (in Russian).

Agadjanian, A.K., 2009. Pliocene-Pleistocene Small Mammals of the Russian Plain. Nauka Press, Moscow, pp. 1-676 (Transactions of the Palaeonlogical institute, Issue 289) (in Russian).

Alexandrowicz, S.W., 1986. Molluscan assemblages from a loess profile at Odonów (Małopolska Upland). Biul. Peryglac. 31, 7-15.

Alexandrowicz, W.P., 1999. Elolution of the malacological assemblages in north Poland during the late glacial and early holocene. Folia Quat. 70, 39-69.

Alexandrowicz, W.P., 2001. Late vistulian and holocene molluscs assemblages from calcareous tufa at the ostrysz hill (podhale basin, S. Poland). Folia Malacol. 9 (3), $159-169$.

Alexandrowicz, W.P., 2002. Mollusc assemblages of an ancient lake in Rózyny near Skowarcz (Zuławy Wiślane, N. Poland). Folia Malacol. 10 (4), 215-224.

Alexandrowicz, W.P., 2009. Malacostratigraphy of vistulian and holocene in Poland. Studia Quaternary 26, 55-63.

Alexandrowicz, W.P., 2011a. Molluscan communities in Vistulian loess located in Chobrzany, a village near Sandomierz (Southern Poland). Geologia 37 (3), 357-373.

Alexandrowicz, W.P., 2011b. Fauna of molluscs from loess profile at wola chroberska (nida basin, southern Poland). Annales Universitatis Mariae Curie-Sklodowska, Sectio B 66 (1), 77-91.

Alexandrowicz, W.P., 2013a. Malacological sequence from profile of calcareous tufa in grón (podhale basin, southern Poland) as an indicator of the late glacial/holocene boundary. Quat. Int. 293, 196-206.

Alexandrowicz, W.P., 2013b. Molluscan communities in late Holocene fluvial deposits as an indicator of human activity: a study in Podhale basin in South Poland. Ekológia 32 (1), 111-125.

Alexandrowicz, W.P., 2013c. Molluscan assemblages in the deposits of landslide dammed lakes as indicators of late Holocene mass movements in the polish Carpathians. Geomorphology 180-181, 10-23.

Alexandrowicz, W.P., 2014. Malacological sequence of Weichselian (MIS 5-2) loess series from a profile in Grodzisko Dolne (Southern Poland) and its palaeogeographic significance. Quat. Int. 319, 109-118.

Alexandrowicz, W.P., 2018. Mollusc assemblages from subatlantic oxbow lake deposits in the Szreniawa river valley near Słomniki (Miechów upland, Southern Poland). Folia Malacol. 26 (4), 249-262.

Alexandrowicz, S., Alexandrowicz, W., 1995a. Molluscan fauna of the upper vistulian and early holocene sediments of south Poland. Biul. Peryglac. 34, 5-18.

Alexandrowicz, S., Alexandrowicz, W., 1995b. Quaternary molluscan assemblages of the polish carpathian. Stud. Geomorphol. Carpatho-Balcanica 29, 41-54.

Alexandrowicz, S., Alexandrowicz, W., 2010. Molluscs of the eemian interglacial in Poland. Ann. Soc. Geol. Pol. 80, 69-87.

Alexandrowicz, W.P., Dmytruk, R., 2007. Molluscs in eemian-vistulian deposits of the kolodiiv section, Ukraine (east carpathian foreland) and their palaeoecological interpretation. Geol. Q. 51 (2), 173-178.

Alexandrowicz, W.P., Rybska, E., 2013. Environmental changes of intramontane basins derived from malacological analysis of profile of calcareous tufa in Niedzica (Podhale basin, Southern Poland. Carpathian journal of earth and environmental sciences 8 (4), 13-26.

Alexandrowicz, W.P., Łanczont, M., Boguckyj, A.B., Kulesza, P., Dmytruk, R., 2014. Molluscs and ostracods of the Pleistocene loess deposits in the Halych site (Western Ukraine) and their significance for palaeoenvironmental reconstructions. Quat. Sci. Rev. 105, 162-180.

Alimbekova, L.I., Danukalova, G.A., Epiphanova, M.S., 1998. Itogi Izucheniya SporovoPyl'tsevykh Spektrov Po Shurfu Peshchery "Zapovednaya" [Results of the Study of Spore-Pollen Spectra from the Cave "Zapovednaya" Pit]. Annual-1996. Informational Materials. UNC RAN, Ufa, pp. 8-12 (in Russian).

Alimbekova, L.I., Danukalova, G.A., Yakovlev, A.G., 2000. Sporovo-pyl'tsevyye issledovaniya golotsenovykh otlozheniy mestonakhozhdeniy «Lemeza II-IV » [Spore and pollen study of the Holocene deposits of the "Lemeza II-IV" localities]. In: Puchkov, V.N. (Ed.), Geological Collection 1. Informational Materials. Ufa, pp. 66-69 (in Russian).

Atlas, Respubliki Bashkortostan [Atlas of Bashkortostan Republic]. Omsk kartographic fabric Press, Ufa, pp. 420 (in Russian).
Bader, O.N., 1964. Novyye paleoliticheskiye mestonakhozhdeniya v peshcherakh Urala [New Palaeolithic localities in the caves of the Urals]. Archaeology and Ethnography of Bashkiria 2, 28 (in Russian).

Bader, O.N., 1971. Smelovskaya II - paleoliticheskaya stoyanka v stepyakh yuzhnogo urala [Smelovskaya II - palaeolithic site in the steppes of the southern Urals]. Materials and research on archeology of the USSR 137 (6), 200-208 Sovetskaya arkheologia (in Russian).

Bibikov, S.N., 1950a. Peshchernyye paleoliticheskiye mestonakhozhdeniya v nagornoy polose Yuzhnogo Urala [Cave Paleolithic locations in the upland belt of the Southern Urals]. Sovetskaya arkheologia 12, 66-104 (in Russian).

Bibikov, S.N., 1950b. Neoliticheskiye i eneoliticheskiye ostatki kul'tury v peshcherakh Yuzhnogo Urala [Neolithic and Eneolithic remnants of culture in the caves of the Southern Urals]. Sovetskaya arkheologia 13, 95-138 (in Russian).

Bobrov, A.E., Kupriyanova, L.W., Litvintseva, M.V., Tararsevich, V.F., 1983. Spory Paporotnikoobraznych I Pyl'tsa Golosemennych I Odnodolnych Rastenii Flory Evropeiskoi Chasti SSSR [Spore of Ferns and Pollen of Gymnosperms and Monocotyledoneae Plants of Flora of the European Part of the USSR]. 2. Nauka Press, Leningrad, pp. 1-200 (in Russian).

Borodin, A.V., 2009. Opredelitel' Zubov Polevok Urala I Zapadnoy Sibiri (Pozdniy Pleystotsen-Sovremennost') [Key to Teeth of Voles of the Urals and Western Siberia (Late Pleistocene-Present)]. Ural Branch of Russian Academy of Sciences Press, Ekaterinburg, pp. 1-99 (in Russian).

Cieszkowski, M., Zuchiewicz, W., Alexandrowicz, W., Wojtal, P., 2010. A new find of mammoth tusk in loess-like sediments of the Zakliczyn basin (Outer Western Carpathians, Poland). Ann. Soc. Geol. Pol. 80, 89-99.

Cohen, K.M., Gibbard, Ph, 2016. G1obal Chronostratigraphical Correlation Table for the Last 2.7 Million Years. V. 2016a. Subcommission on Quatemary Stratigraphy. Intenational Commission on Stratigraphy, Cambridge, England. http://www. quaternary.stratigraphy.org.uk/charts.

Danilovskyi, I.V., 1955. Opornyy Litologo-Stratigraficheskiy Razrez Otlozheniy Skandinavskogo Oledeneniya Russkoy Ravniny I Rukovodyashchiye Chetvertichnyye Mollyuski [Scandinavian Glaciation Deposits Key Site of the Russian Plain and Quaternary Molluscs]. Transactions of the VSEGEI 9 Gosgeoltekh Press, Moscow (in Russian).

Danukalova, G.A., 2007. Stratigraphyia kvartera Yuzhnogo Preduralya [Stratigraphy of Quaternary of the Southern Fore-Urals]. In: Geological Events of the Neogene and Quaternary of Russia: Modern Condition of the Stratigraphical Schemes and Palaeogeographical Reconstructions. Materials of All-Russian Scientific Meeting. GEOS Press, Moscow, pp. 40-43 (in Russian).

Danukalova, G.A., 2009. Stratigraficheskoye raschleneniye verkhnechetvertichnykh otlozheniy Yuzhnoural'skogo regiona [Stratigraphic dismemberment of the Upper Quaternary sediments of the South Ural region]. In: Puchkov, V.N. (Ed.), Geological Collection, 8. Informational Materials. DizainPoligrafServis Press, Ufa, pp. $40-48$ (in Russian).

Danukalova, G.A., 2010. The Refined Quaternary stratigraphical scale of the Cisuralian region and main events in the south Urals. Stratigr. Geol. Correl. 18 (3), 331-348.

Danukalova, G.A., Yakovlev, A.G., Alimbekova, L.I., Kosintsev, P.A., Morozova, E.M., Eremeev, A.A., 2002b. Biostratigrafiya chetvertichnykh otlozheniy peshcher i shirotnogo techeniya r. Beloy [Biostratigraphy of the Quaternary deposits of the caves and river terraces from the latitudinal current of the Belaya River valley]. In: Gareev, E.Z. (Ed.), Ecological Aspects of the Yumaguzino Water Reseourvar. Gilem Press, Ufa, pp. 32-57 (in Russian).

Danukalova, G., Yakovlev, A., Alimbekova, L., Yakovleva, T., Morozova, E., Eremeev, A., Kosintsev, P., 2008. Biostratigraphy of the Upper Pleistocene (Upper Neopleistocene)-Holocene deposits of the Lemeza River valley of the Southern Urals region (Russia). Quat. Int. 190 (1), 38-57.

Danukalova, G., Yakovlev, A., Osipova, E., Kurmanov, R., Yakovleva, T., 2017. Palaeoenvironment of the Late Holocene at the Tashmurun and Archaeologists Grottoes archaeological sites of the Belaya River valley (the Southern Urals, Russia), In: Resumes. XXI-eme colloque international du GMPCA. UMR 6566 "CReAAH" Archeologie, Archeosciences, Histoire. 18-21 avril 2017. Rennes. Rennes University, pp. 36.

Danukalova, G., Yakovlev, A., Osipova, E., Yakovleva, T., Kosintsev, P., 2011. Biostratigraphy of the late upper Pleistocene (upper Neopleistocene) to holocene deposits of the Belaya River valley (southern Urals, Russia). Quat. Int. 231, 28-43.

Danukalova, G., Lefort, J.-P., Osipova, E., Monnier, J.-L., 2013. Recent advances in the stratigraphy of the upper Pleistocene of westernmost Europe: La haute ville and bréhat cliffs (northern brittany, France). Quat. Int. 284, 30-44.

Danukalova, G., Osipova, E., Yakovlev, A., Yakovleva, T., 2014. Biostratigraphical characteristic of the holocene deposits of the southern Urals. Quat. Int. 328-329, 244-263.

Danukalova, G., Osipova, E., Khenzykhenova, F., Sato, T., 2015. The molluscs' record: a tool for reconstruction of the Late Pleistocene (MIS 3) palaeoenvironment of the Bol'shoj Naryn site area (Fore-Baikal region, Eastern Siberia, Russia). Quat. Int. 355, 24-33.

Danukalova, G., Kurmanov, R., Yakovlev, A., Osipova, E., Zinovyev, E., Arslanov, Kh, 2016. Palaeoenvironment of the middle and upper Neopleistocene at the gornovo upper palaeolithic site (southern ural foreland, Russia). Quat. Int. 420, 24-46.

Danukalova, G.A., Lefort, J.P., Monnier, J.L., Osipova, E.M., Pustoc'h, F., Le Bannier, J.Ch, 2017a. Sedimentological and malacological comparisons between the upper saalian and upper weichselian loess superimposed in the nantois cliff (brittany, France): reconstruction of their environments south of the British ice sheet. ArcheoSciences. Revue d'Archeometrie 41 (2), 63-84.

Danukalova, G.A., Yakovlev, A.G., Puchkov, V.N., Danukalov, K.N., Agadjanian, A.K., Kolfschoten, Th van, Eremeev, A.A., Morozova, E.M., 2002. Excursion Guide of the INQUA SEQS - 2002 Conference, 30 June - 7 July, 2002, Ufa (Russia). Dauria Press, 
Ufa, pp. 1-139.

Danukalova, G.A., Yurin, V.I, Kosintsev, P.A., Osipova, E.M., Kurmanov, R.G., 2018. Biostratigraficheskiye issledovaniya otlozheniy verkhnego pleystotsena i golotsena peshchery Sikiyaz-Tamak 7 (Yuzhnyy Ural, Rossiya) [Biostratigraphical study of the Upper Pleistocene and Holocene deposits of the Sikiyaz-Tamak 7 cave (Southern Fore-Urals, Russia)]. Geologicheskii Vestnik 1, 144-161.

Dobrowolski, R., 2005. Chronotratigraphy of calcareous mire sediments at Zawadowka (Estern Poland) and their use in palaeogeographical reconstruction. Geochronometria $24,69-79$.

Dobrowolski, R., Pidek, I., Alexandrowicz, W., Hałas, S., Pazdur, A., Piotrowska, N., Buczek, A., Urban, D., Melke, J., 2012. Interdisciplinary studies of spring mire deposits from Radzików (South Podlasie Lowland, Eastb Poland) and their significance for palaeoenvironmental reconstruction. Geochronometria 39 (1), 10-29.

Eremeev, A.A., 2003. Rezul'taty palinologicheskogo izucheniya pozdnepleystotsenovykh otlozheniy peshchery "Verkhnyaya" (Yuzhnyy Ural) [The results of a palynological study of the Upper Pleistocene sediments of the Verkhnyay cave (Southern Urals)]. In: Problems of Global and Regional Ecology: Materials of the Young Scientists' Conference, March 31 - April 4, 2003. Akademkniga Press, Ekaterinburg, pp. 46-50 (in Russian).

Eremeev, A.A., Kurmanov, R.G., 2011. Palinologicheskaya kharakteristika golotsenovykh i verkhneneopleystotsenovykh otlozheniy peshchery Shul'gan-Tash [Palynological characteristics of Holocene and Upper Pleistocene sediments of the Shulgan-Tash cave]. In: Problems of Modern Palynology: Proceedings of the XIII Russian Palinology Conference, vol. 2. Institute of Geology of the Komi Scientific Centre RAS Press, Syktyvkar, pp. 84-87 (in Russian).

Fadeeva, T.V., Kosintsev, P.A., 2015. Golotsenovye fauny mlekopitayuschikh (Lipotyphla, Chiroptera, Lagomorpha, Rodentia) Yuzhnogo Zauralia [Holocene faunas of mammals (Lipotyphla, Chiroptera, Lagomorpha, Rodentia) of Southern Trans-Urals]. In: Fundamental Problems of Quaternary, Results of the Study and the Main Trends of Further: Proceeding of the IX All-Russian Conference on Quaternary Research (Irkutsk, September 15-20, 2015). V.B. Sochava Institute of Geography SB RAS Publishers, Irkutsk, pp. 473-475 (in Russian).

Fadeeva, T.V., Kosintsev, P.A., Gimranov, D.O., Yakovlev, A.G., Gasilin, V.V., Plasteeva, N.A., Smirnov, N.G., 2018. A finding of the red squirrel (Rodentia, Sciuridae, Sciurus vulgaris Linnaeus, 1758) and forest dormouse (Rodentia, Gliridae, Dryomys nitedula Linnaeus, 1778) in the Pleistocene of the Southern Urals. Dokl. Biol. Sci. 481 (1), $160-162$.

Fadeeva, T.V., Kosintsev, P.A., Gimranov, D.O., 2019. Mlekopitayuschie gornoi chasti Yuzhnogo Urala v poslednee mezhlednikovie [Mammals of the mountain part of the Southern Urals during Last Interglacial]. Zoologicheskij zhurnal (Russian Journal of Zoology) 98 (11), 1304-1322 (in Russian).

Falkner, G., Ripken, T.E.J., Falkner, M., 2002. Mollusques continentaux de France. Liste du references annotees et Bibliographie. Patrimoines naturels 52. Museum National d' Histoire Naturelle (Paris), France, pp. 1-350.

Fükon, L., 1987. Evolution of the mollusca fauna of the Hungarian Uplands in the Holocene. Holocene environment in Hungary. In: Contribution of the INQUA Hungarian National Committee to the XII-Th INQUA Congress. Geographical research institute Hungarian Academy of Sciences Press, Budapest, pp. 49-56.

Gimranov, D.O., Kosintsev, P.A., 2017a. Pervaya nakhodka dikobraza (Hystrix sp.) i kabana (Sus scrofa) v pozdnem pleystotsene Yuzhnogo Urala [The first find of porcupine (Hystrix sp.) and wild boar (Sus scrofa) in the Late Pleistocene of the Southern Urals]. In: Fundamental Problems of the Quarter: the Results of the Study and the Main Directions of Further Research. Proceedings of the X All-Russian Meeting on the Study of the Quaternary Period. Moscow, September 25-29, 2017. GEOS Press, Moscow, pp. 89-90 (in Russian).

Gimranov, D.O., Kotov, V.G., Rumyantsev, M.M., Yakovlev, A.G., Sotnikova, M.V., Nurmukhametov, I.M., Sataev, R.M., Kosintsev, P.A., 2016a. Peshchera Imanay novoye paleontologicheskoye $\mathrm{i}$ arkheologicheskoye mestonakhozhdeniye na Yuzhnom Urale [Imanai Cave - a new paleontological and archaeological site in the South Urals]. April 4-8, 2016 In: 100th Anniversary of the Paleontological Society of Russia. Problems and Prospects of Paleontological Research: Materials of the LXII Session of the Paleontological Society. Saint Patersburg, pp. 231-233 (in Russian).

Gimranov, D.O., Kosintsev, P.A., Nurmukhametov, I.M., Nekrasov, A.E., 2016b. Pervaya nakhodka dikobraza (Hystrix sp.) i kabana (Sus scrofa) v pozdnem pleystotsene Yuzhnogo Urala [The first find is a porcupine (Hystrix sp.) and a boar (Sus scrofa) in the Late Pleistocene of the Southern Urals.]. In: Nature, Science and Tourism: a Collection of Materials of the All-Russian Scientific and Practical Conference Dedicated to the 30th Anniversary of the Bashkiria National Park. Gilem Press, Bashkirskaya Encyclopedia Press, Ufa, pp. 137-142 (in Russian).

Gimranov, D.O., Kotov, V.G., Rumyantsev, M.M., 2017b. Rezul'taty kompleksnykh issledovaniy mnogosloynoy must'yerskoy stoyanki v peshchere Imanay-1 na Yuzhnom Urale [The results of a comprehensive study of multi-layered Mousterian parking in the cave Imanai-1 in the Southern Urals.]. In: Derevianko, A.P., Tishkin, A.A. (Eds.), V (XXI) All-Russian Archaeological Congress [Electronic Resource]: a Collection of Scientific Papers. Altai State University Press, Barnaul (in Russian).

Gimranov, D.O., Kotov, V.G., Rumyantsev, M.M., Silaev, V.I., Yakovlev, A.G., Yakovleva, T.I., Zelenkov, N.V., Sotnikova, M.V., Devyashin, M.M., Plasteeva, N.A., Zaretskaya, N.E., Nurmukhametov, I.M., Smirnov, N.G., Kosintsev, P.A., 2018. A mass burial of fossil Lions (Carnivora, Felidae, Panthera (Leo) ex gr. fossilis-spelaea) from Eurasia. Dokl. Biol. Sci. 482, 234-237 (in Russian).

Glöer, P., 2002. Die Süsswassergastropoden Nord- und Mitteleuropas. ConchBooks, Hackenheim, pp. 1-327.

Gozhik, P.F., 1965. Mollyuski Chetvertichnykh (Antropogenovykh) Otlozheniy Terras Pruta//Materialy Po Chetvertichnomu Periodu Ukrainy [Quaternary (Anthropogene) Molluscs of the Prut River Terraces]. Materials on the Quaternary Period of Ukraine. Naukova Dumka Press, Kiev, pp. 1-332 (in Russian).
Grichuk, V.P., Zaklinskaya, E.D., 1948. Analiz Iskopaemych Pyl’tsy I Spor I Ego Primenenie V Paleogeographii [The Analysis of Fossil Pollen and Spore and Using These Data in Paleogeography]. GeographGIZ Press, Moscow, pp. 25-48 (in Russian).

Heinrich, W.D., 1982. Zur Evolution und Biostratigraphie von Arvicola (Rodentia, Mammalia) im Pleistozan Europas. Zeitschrift fur Geologische Wissenschaften 10, 683-735.

Il'ina, L.B., 1966. Istoriya gastropod Chernogo morya [History of the gastropods of the Black Sea]. In: Proceedings of the Palaeontological Institut 110. Nauka Press, Moscow, pp. 1-229 (in Russia).

Izvarin, E.P., 2004. Novyye materialy po faune melkikh mlekopitayushchikh pleystotsengolotsenovogo perekhoda na zapadnom sklone Srednego Urala [New data about small mammal fauna of Pleistocene-Holocene boundary at the western slope of Middle Urals]. In: Ecological Mechanisms of Dynamics and Stability of the Biota. Contributions to the Young Scientists' Conference. Academkniga Press, Ekaterinburg, pp. 91-92 (in Russian).

Izvarin, E.P., 2017. Formirovaniye Fauny Melkikh Rastitel'noyadnykh Mlekopitayushchikh Zapadnogo Sklona Srednego Urala V Pozdnem Pleystotsene I Golotsene [Formation of the Fauna of Small Herbivorous Mammals of the Western Slope of the Middle Urals in the Late Pleistocene and Holocene]. Ph.D. Thesis. Institute of Plant and Animal Ecology, Ural branch, RAS, Ekaterinburg, Russia, pp. 1-20 (in Russian).

Izvarin, E.P., Smirnov, N.G., 2015. Melkiye mlekopitayushchiye rannego golotsena iz mestonakhozhdeniya alikayev kamen' (sredniy ural) [Early-Holocene small mammals from site Alikaev kamen' (middle Urals)]. Actual problems of the humanities and natural sciences 10 (1), 36-41 (in Russian).

Kaplin, P.A. (Ed.), 1987. Kompleksnyye Biostratigraficheskiye Issledovaniya [Complex Biostratigraphic Investigations]. Moscow University Press, Moscow, pp. 1-107 (in Russian).

Karacharovsky, V.V., 1951. Pozdnechetvertichnaya fauna peshcher basseyna r. Yuryuzan (Yuzhnyy Ural) [Late Quaternary fauna of caves of Yuryuzn River basin]. In: In: Bryusov, A.Ya (Ed.), Materialy I Issledovaniya Po Arkheologii Urala I Priuralya, vol. 2. Academy of Sciences of the USSR Press, Moscow, pp. 244-269 (Materialy i issledovaniya po arkheologii SSSR, issue 21) (in Russian).

Kerney, M.P., Cameron, R.A.D., 1999. Guide des Escargots et limaces d' Europe. Delachaux et Niestle S.A. 3, Lausanne, pp. 1-70.

Khenzykhenova, F.I., Lipnina, E.A., Danukalova, G.A., Shchetnikov, A.A., Osipova, E.M. Semenei, E.Y., Tumurov, E.G., Lokhov, D.N., 2019. The area surrounding the world famous geoarchaeological site Mal'ta (Baikal Siberia): new data on the chronology, archaeology, and fauna. Quat. Int. 509, 17-29.

Khotinsky, N.A., 1977. Golotsen Severnoi Evrazii [Holocene of the Northern Eurasia]. Nauka Press, Moscow (in Russian).

Kosintsev, P.A., 2003. Arkheologicheskie materially iz raskopok Tashmurunovskogo grota $\mathrm{v}$ verkhoviyakh reki Beloi [Archaeozoological material from excavations Tashmurun Grotto in the upper reaches of the Belaya river]. The Ufa archaeological vestnik 4, 148-162 (in Russian).

Kosintsev, P.A., Bachura, O.P., 2013. Late Pleistocene and Holocene mammal fauna of the Southern Urals. Quat. Int. 284, 161-170.

Kosintsev, P.A., Sataev, R.M., 2005. Fauna mlekopitayuschikh iz mestonakhozhdeniya asha I (yuzhnyi ural) [Mammal fauna from Asha I site (Southern Urals)]. In: Kosintsev, P.A. (Ed.), Ural and Siberia Faunas at Pleistocene and Holocene. Biota of Northern Eurasia in Cenozoic. Issue 4. Rifey Press, Chelyabinsk, pp. 113-147 (in Russian).

Kosintsev, P.A., Yurin, V.I., 2003. Zhertvennyy kompleks iz peshchery Sikiyaz-Tamak 1 [Sacrificial complex from Sikiyaz-Tamak 1 cave]. In: Man in the Space of Ancient Cultures, pp. 69-72 Chelyabinsk.

Kosintsev, P., Danukalova, G., Osipova, E., Yakovlev, A., Alimbekova, L., Popova-Lvova, M., 2013. Palaeoenvironment of the Late Pleistocene - Holocene interval in the Tanalyk river valley of the Southern Trans-Ural region (Russia). Quat. Int. 284, 74-84.

Kosintsev, P.A., Kotov, V.G., Panteleev, A.V., Yakovlev, A.G., 2018. Ispol'zovaniye Izvestnyakovogo Syr'ya V Verkhnem Paleolite Urala (Po Materialam Stoyanki V Peshchere Balatukai) (Use of Limestone Raw Materials in the Ural Upper Palaeolithic Based on the Materials of the Cave Balatukai Site). Vestnik of the Perm University 5-19.

Kosintsev, P., Mitchell, K.J., Deviese, Th, Plicht, J. van der, Kuitems, M., Petrova, E., Tikhonov, A., Higham, Th, Comeskey, D., Turney, Ch, Cooper, A., Kolfschoten, Th van, Stuart, A.J., Lister, A.M., 2019. Evolution and extinction of the giant rhinoceros Elasmotherium sibiricum sheds light on late Quaternary megafaunal extinctions. Nature Ecology \& Evolution 3 (1), 31-38.

Kotov, V.G., 2009. Paleolit [Palaeolithic]. In: Kulsharipov, M.M. (Ed.), History of the Bashkir People. Nauka Press, Moscow, pp. 23-53 (in Russian).

Kudryashov, I.K., 1969. Putevoditel Po Kapovoi Pezshere [Kapova Cave Guide]. Bashkirskoe Knizhnoe izdatelstvo, Ufa, pp. 1-125 (in Russian).

Kunitsa, N.A., 2007. Priroda Ukraini V Pleistocene (Soglasno Malakologiceskomu Analisu) [Nature of Ukraine during Pleistocene (According to Malacological Analysis)]. Ruta Press, Chernovcy, pp. 1-240 (in Russian).

Kupriyanova, L.V., Aleshina, L.A., 1972. Pyl'tsa I Spory Rastenii Flory Evropeiskoi Chasti SSSR [Pollen and Spore of the European Part of the USSR Plants]. 1. Nauka Press, Leningrad, pp. 3-166 (in Russian).

Kupriyanova, L.V., Aleshina, L.A., 1978. Pyl'tsa I Spory Rastenii Flory Evropeiskoi Chasti SSSR. [Pollen and Spore of the European Part of the USSR Plants]. 2. Nauka Press, Leningrad, pp. 10-184 (in Russian).

Kuzmin, Y.V., Kosintsev, P.A., Vasiliev, S.K., Fadeeva, T.V., Hodgins, G.W.L., 2017. The northernmost and latest occurrence of the fossil porcupine (Hystrix brachyura vinogradovi Argyropulo, 1941) in the Altai Mountains in the Late Pleistocene (ca. 32,000-41,000 cal BP). Quat. Sci. Rev. 161, 117-122. 
Kuzmina, S.A., 2000. Faunisticheskiye dannyye po pozdnepaleoliticheskoy stoyanke Smelovskaya 2 na yuzhnom urale [Faunal data from the Late-Palaeolithic site of Smelovskaya II in the Southern Urals]. In: Pleistocene and Holocene Urals Faunas. Biota of Northern Eurasia in Cainozoe. Issue 1. Rifey, Chelyabinsk, pp. 137-153 (in Russian).

Kuzmina, E.A., 2002. Iskopayemyye melkiye mlekopitayushchiye iz karstovykh polostey Yuzhnogo Zaural'ya [Fossil small mammals from karst caves of the South TransUrals]. In: Biota of Mountain Territory: History and Modern Station. Contributions to the Young Scientists' Conference. Academkniga Press, Ekaterinburg, pp. 92-97 (in Russian).

Kuzmina, E.A., 2003. Late Pleistocene and Holocene small mammals from karst caves of the South Trans-Urals. In: Abstracts of the Fourth European Congress of Mammalogy. Brno, pp. 148.

Kuzmina, E.A., 2003b. Pozdnepleystotsenovyye i golotsenovyye soobshchestva melkikh mlekopitayushchikh iz peshchernykh mestonakhozhdeniy Yuzhnogo Zaural'ya [Late Pleistocene and Holocene communities of small mammals reconstructed from cave sites of the South Trans-Urals]. In: Quaternary Palaeozoology in the Urals. Publishing House of the Ural State University, Ekaterinburg, pp. 193-210 (in Russian).

Kuzmina, E.A., 2009. Late Pleistocene and Holocene small mammal faunas from the South Trans-Urals. Quat. Int. 201, 25-30.

Kuzmina, I.E., Abramson, N.I., 1997. Ostatki mlekopitayushchikh v kapovoy peshchere na yuzhnom urale [Small mammal remains from the Shulgan-Tash Cave of the Southern Urals]. In: Cave Palaeolitic of the Urals, Materials of the International Conference. Print press, Ufa, pp. 124-127 (in Russian).

Kuzmina, E.A., Smirnov, N.G., Kourova, T.P., 2001. Fauny gryzunov Yuzhnogo Zaural'ya $v$ pozdnem pleystotsene - golotsene [Rodent faunas of the Southern Trans-Urals in the Late Pleistocene - Holocene]. In: Modern Problems of Population, Historical and Applied Ecology. Contributions to the Young Scientists' Conference 2. Ekaterinburg, pp. 121-127 (in Russian).

Lapteva, E.G., 2006. Palinologicheskaya kharakteristika rykhlykhotlozheniy peshchery Syrtinskaya (Yuzhnoye Zaural'ye) [Palynological characteristic of the unconsolidated deposits of the Syrtinskaya cave (Southern Trans-Urals)]. In: Ekologiya V Menyayushchemsya Mire. Materialy Konferentsii Molodykh Uchenykh, 24-28 Aprelya 2006 G. [Ecology in a Changing World. Proceedings of the Conference of Young Scientists, April 24-28, 2006]. Akademkniga Publishing House, Ekaterinburg, pp. 126-137 (in Russian).

Lebedev, V.D., 1960. Presnovodnaya Chetvertichnaya Ikhtiofauna Evropeiskoi Chast SSSR [Freshwater Quaternary Ichthyofauna of the European Part of the USSR]. Moscow University Press, Moscow, pp. 1-404 (in Russian).

Likharev, I M, Rammelmeier, E S, 1952. Nazemnye molluski fauny SSSR [Land molluscs of the Fauna of the USSR]. Academy of Sciences of USSR Press, Leningrad, Moscow, pp. 511 (Determinative Tables of the USSR Fauna. Proceedings of the Zoological Institute of the USSR Academy of Sciences; v. 43) (in Russian).

Ložek, V., 2000. Holocene of the bohemian karst. GeoLine 11, 101-103.

Lyakhnitsky, Y., 2002. Shulgan-Tash Cave. Kitap Press, Ufa, pp. 1-198 (in Russian).

Marković, S.B., Oches, E.A., Gaudenyi, T., Jovanović, M., Hambach, U., Zöller, L., Sümegi, P., 2004. Paleoclimate record in the late Pleistocene loess-paleosol sequence at miseluk (vojvodina, Serbia). Quaternaire 15, 361-368.

Marković, S.B., Oches, E., Sümegi, P., Jovanović, M., Gaudenyi, T., 2006. An introduction to the upper and middle Pleistocene loess-paleosol sequences of ruma brickyard, vojvodina, Serbia. Quat. Int. 149, 80-86.

Marković, S.B., Oches, E.A., McCoy, W.D., Gaudenyi, T., Frechen, M., 2007. Malacological and sedimentological evidence for "warm" climate from the Irig loess sequence (Vojvodina, Serbia). Geophysics, Geochemistry and Geosystems 8 (9), 1-12.

Marković, S.B., Bokhorst, M., Vandenberghe, J., Oches, E.A., Zöller, L., McCoy, W.D., Gaudenyi, T., Jovanović, M., Hambach, U., Machalett, B., 2008. Late Pleistocene loess-paleosol sequences in the vojvodina region, north Serbia. J. Quat. Sci. 23, 73-84.

Martin, S., Magnin, F., Chevillot, P., 2005. Mise en evidence des discontinuites spatiales et temporelles dans l'anthropisation de la plaine de la Vistrenque a nimes (Gard) durant L'Holocene apport de l'analyse malacologique. Quaternare 16 (4), 339-353.

Moine, O, 2008. West-European malacofauna from loess deposits of the Weichselian Upper Pleniglacial: compilation and preliminary analysis of the database. Quaternaire 19 (1), 11-29.

Moine, O., Rousseau, D.-D., Antoine, P., 2005. Terrestrial molluscan records of Weichselian Lower to Middle Pleniglacial climatic changes from the Nussloch loess series (Rhine Valley, Germany): the impact of local factors. Boreas 34, 363-380.

Monnier, J.L., 1980. Le paleolithique de la Bretagne dans son cadre géologique. Travaux du Laboratoire d'Anthropologie e Prehistoire e Protohistoire et Quaternaire Armoricains. Serie C. No. 27. 1. Thése. Université de Rennes, pp. 1-607.

Nederlandse Fauna 2, 1998. De Nederlandse Zoetwatermollusken. Recente en fossiele weekdieren uit zoet en brak water. In: Gittenberger, Redactie E., Janssen, A.W. (Eds.), Nationaal Natuurhistorisch museum Naturalis KNNV uitgeverij. European Invertebrate survey 288 p.DG.

Nekrasov, A.E., 1992. Ostatki ryb iz pescher i grotov v verkhoviyakh r. Sim [The remains of fishes from the caves and grottoes in the upper reaches of the Sim river]. In: Petrin, V.T. (Ed.), Paleoliticheskoye Svyatilishche V Ignatiyevskoy Peshchere Na Yuzhnom Urale [Palaeolithic Sanctuary in Ignatievskaya Cave in the Southern Urals]. Nauka Press, Novosibirsk, pp. 188-191 (in Russian).

Nemkova, V.K., 1976. Istoriya rastitel'nosti Predural'ya za pozdneye- i poslelednikovoye vremya [History of Fore-Urals vegetation during late and post-glacial time]. In: Aktual'nyye Voprosy Sovremennoy Geokhronologii [Current Issues of Modern Geochronology]. Nauka Press, Moscow, pp. 259-275 (in Russian).

Osipova, E.M., Danukalova, G.A., Khenzykhenova, F.I., 2018. Novyye dannyye o mollyuskakh sartanskogo gorizonta verkhnego neopleystotsena razreza Bokhan (Pribaykal'ye, Rossiya) [New data on the molluscs of the Sartan Horizon (the Upper
Neopleistocene) from the Bokhan section (Fore-Baikal area, Russia)]. Geologicheskii Vestnik 3, 70-78 (in Russian with English summary).

Pacher, M., Stuart, A.J., 2009. Extinction chronology and palaeobiology of the cave bear (Ursus spelaeus). Boreas 38 (2), 189-206.

Petrin, V.T., 1992. Paleoliticheskoye Svyatilishche V Ignatiyevskoy Peshchere Na Yuzhnom Urale [Palaeolithic Sanctuary in Ignatievskaya Cave in the Southern Urals]. Nauka Press, Novosibirsk, pp. 1-207 (in Russian).

Puchkov, V.N., 2010. Geologiya Urala I Priural'ya (Aktual'nyye Voprosy Stratigrafii, Tektoniki, Geodinamiki I Metallogenii) [Geology of the Urals and Cis-Urals (Actual Problems of Stratigraphy, Tectonics, Geodynamics and Metallogeny)]. DesignPoligraphService Press, Ufa, pp. 1-280 (in Russian).

Ratnikov, V.Y., 2002. Pozdnekaynozoyskiye Zemnovodnyye I Cheshuychatyye Presmykayushchiyesya Vostochno-Yevropeyskoy Ravniny [Late Cenozoic Amphibians and Reptiles of the Eastern-European Plain]. Voronezh State University Press, Voronezh, pp. 1-138 (Proceedings of the Research Institute of Geology of the Voronezh State University; Issue 10) (in Russian).

Ratnikov, V.Y., 2009. Iskopayemyye Ostatki Sovremennykh Vidov Zemnovodnykh I Cheshuychatykh Presmykayushchikhsya Kak Material Dlya Izucheniya Istorii Ikh Arealov [Fossil Remains of Modern Amphibian and Scaly Reptiles as Materials for Studying the History of Their Ranges]. 2009. Voronezh State University Press, Voronezh, pp. 1-91 (Proceedings of the Research Institute of Geology of the Voronezh State University; Issue 59) (in Russian).

Ravazzi, C., 2004. An overview of the Quaternary continental stratigraphic units based on biological and climatic events in Italy. II Quaternario 16 (1 Bis), 11-13.

Razhev, D.I., Kosintsev, P.A., Ulitko, A.I., 2005. Fauna krupnykh mlekopitayushchikh pozdnego pleystotsena i golotsena iz grota Bobylek (Sredniy Ural) [Late-Pleistocene and holocene fauna of large mammals from grotto Bobyliok (Middle Urals)]. In: Faunas of the Urals and Siberia during Pleistocene and Holocene, Collection of Scientific Papers. Publishing House Riphei, Chelyabinsk, pp. 190-211 (in Russian).

Reshetnikov, YuS., 1998. Annotirovannyi Catalog Kruglorotykh I Ryb Kontinentalnykh Vod Rossii ) [Annotated Chek-List of Cyclostomata and Fishes of the Continental Waters of Russia]. Moscow. pp. 220 (in Russian).

Sataev, R.M., 2005. Ekologicheskaya Interpretatsiya Paleofaunisticheskikh Materialov (Na Primere Golocenovykh Mestonakhozhdenii Nazemnykh Pozvonochnykh Bashkirskogo Yuzhnogo Urala) [Ecological Interpretation of Palaeofaunistic Materials (By the Example of Holocene Locations of Terrestrial Vertebrates of the Bashkir Southern Urals]. PhD. Thesis. Kazan. Russia. 23 pp. (in Russian).

Sato, T., Khenzykhenova, F., Simakova, A., Danukalova, G., Morozova, E., Yoshida, K. Kunikita, D., Kato, H., Suzuki, K., Lipnina, E., Medvedev, G., Martynovich, N., 2014. Paleoenvironment of the Fore-Baikal region in the Karginian interstadial: results of the interdisciplinary studies of the Bol'shoj Naryn site. Quat. Int. 333, 146-155.

Saveliev, N.S., Kotov, V.G., Ovsynnikov, V.V., Rumyantcev, M.M., Ruslanov, E.V., Akhmetova, E.A., 2018. Drevnosti Bashkirskogo Urala [Antiquities of the Bashkir Urals]. Informreklama Press, Ufa, pp. 1-216.

Sčelinskij, V.E., Širokov, V.N., 1999. Höhlenmalerei im Ural. Kapova und Ignatievka. Die altsteinzeit-lichen Bilderhöhlen im südlichen Ural. Jan Thorbecke Verlag, Sigmarigen, pp. 1-171.

Shchelinsky, V.E., 1989. Some results of new investigations at the Kapova cave in the southern Urals. Proc. Prehist. Soc. 55, 181-191.

Shchelinsky, V.E., 1997. Paleogeograficheskaya sreda i arkheologicheskiy kompleks verkhnepaleoliticheskogo svyatilishcha peshchery Shul'gan-Tash (Kapovoy) [Palaeogeographical surroundings and archaeological complex of the Upper Palaeolithic sanctuary of the Shulgan-Tash cave (Kapova)]. In: The Cave Palaeolith of the Urals. Materials of the International Conferense, September 9-15, 1997. Ufimian Scientific Centre RAS, Ufa, pp. 29-38 (in Russian).

Shick, S.M., 2014. A modern approach to the Neopleistocene stratigraphy and palaeogeography of Central European Russia. Stratigr. Geol. Correl. 22 (2), 219-230.

Shileyko, A.A., 1978. Nazemnyye Mollyuski Nadsemeystva Helicoidea [Terrestrial Molluscs of the Helicoidea Superfamily]. Nauka Press, Leningrad, pp. 1-384 (Fauna of the USSR. Molluscs. V. 3; Issue 6) (in Russian).

Shileyko, A.A., 1984. Nazemnyye Mollyuski Podotryada Pupillina Fauny SSSR (Gastropoda, Pulmonata, Geophila) [Terrestrial Molluscs of the Suborder Pupillina of the USSR Fauna (Gastropoda, Pulmonata, Geophila)]. Nauka Press, Leningrad, pp. 1-399 (Fauna of the USSR. Molluscs. New Series, N 130, V. 3 (3)) (in Russian).

Shileyko, A.A., Likharev, I.M., 1986. Nazemnyye mollyuski semeystva yantarok (Succineidae) fauny SSSR [Terrestrial molluscs of the Succineidae family of the USSR fauna]. In: Fauna, Sistematika I Filogeniya Bespozvonochnykh Zhivotnykh. Sbornik Trudov Zoologicheskogo Muzeya, vol. XXIV. Izdatel'stvo Moskovskogo universiteta, Moscow, pp. 197-239 (in Russian).

Shirokov, V.N., 2009. Ural'skiye Pisanitsy. Yuzhnyy Ural [Ural Petroglyphs. Southern Urals]. AMB Publisher, Ekaterinburg, pp. 1-33 (in Russian).

Shirokov, V.N., Petrin, V.T., 2013. Iskusstvo Lednikovogo Veka. Ignatiyevskaya I Serpiyevskaya 2 Peshchery Na Yuzhnom Urale [The Art of the Glacial Age. Ignatievskaya and Serpievskaya 2 Caves in the Southern Urals]. "Azhur" Publishing House, Ekaterinburg, pp. 1-190 (in Russian).

Shorin, A.F., 1992. Arkheologicheskiye materialy pozdnego vremeni (bronzovyy vek srednevekov'ye) iz Ignatiyevskoy peshchery [Late-time archaeological materials (Bronze Age - middle Ages) from the Ignatievskaya Cave]. In: Petrin, V.T. (Ed.) Paleoliticheskoye Svyatilishche V Ignatievskoy Peshchere Na Yuzhnom Urale [Palaeolithic Sanctuary in Ignatievskaya Cave in the Southern Urals]. Nauka Press, Novosibirsk, pp. 198-205 (in Russian).

Smirnov, N.G., 1993. Melkiye Mlekopitayushchiye Srednego Urala V Pozdnem Pleystotsene I Golotsene [Small Mammals of the Middle Urals at the Late Pleistocene and Holocene]. Nauka Press, Ekaterinburg, pp. 1-64 (in Russian).

Smirnov, N.G., Kuzmina, E.A., 2001. Rekonstruktsiya sredy obitaniya drevnego naseleniya stepnykh rayonov Urala po mikropaleoteriologicheskim materialam 
[Reconstruction of the habitat of the ancient population of the steppe regions of the Urals according to micropaleoteriological materials]. In: Abstracts of the XV Uralian Archaeological Meeting, April 17-21, 2001. Orenburg State Pedagogical University Press, Orenburg, pp. 32-33 (in Russian).

Smirnov, N.G., Sadykova, N.O., 2003. Istochniki pogreshnostey pri faunisticheskikh rekonstruktsiyakh $\mathrm{v}$ chetvertichnoy paleozoologii [Sources of errors in faunal reconstructions in Quaternary paleozoology]. In: Quaternary Palaeozoology in the Urals. Ural University Press, Ekaterinburg, pp. 98-115 (in Russian).

Smirnov, N.G., Bolshakov, V.N., Kosintcev, P.A., Panova, N.K., Korobeinikov, YuI., Olshvang, V.N., Erokhin, N.G., Bykova, G.V., 1990. Istoricheskaya Ekologiya Zhivotnykh Yuzhnogo Urala [Historical Ecology of Animals of the Southern Urals] Urals Branch of the USSR Academy of Sciences Press, Sverdlovsk (in Russian).

Smirnov, N.G., Kosintsev, P.A., Kuzmina, E.A., Izvarin, E.P., Kropacheva, YuE., 2014. The ecology of Quaternary mammals in the Urals]. Russ. J. Ecol. 45 (6), 449-455.

Sokolov, YuV. Kapova cave. Bashkirian encyclopedy. Circulation date August 1, 2018 (in Russian). http://xn—-7sbacsfsccnbdnzsqis3h5a6ivbm.xn-p1ai/index.php/2statya/13126-kapova-peshchera.

Sokolov, YuV. Idrisovo cave. Bashkirian encyclopedy. Circulation date August 1, 2018 (in Russian). http://xn—7sbacsfsccnbdnzsqis3h5a6ivbm.xn-p1ai/2-statya/12522idrisovskaya-peshchera.html.

Stefanovsky, V.V., 1997. Explanatory notes to the stratigraphic sheme of Quaternary deposits of Urals. In: Explanatory Notes to the Stratigraphic Schemes of Urals. Regional Stratigraphic Commission Press, Ekaterinburg, pp. 97-139 (in Russian).

Stefanovsky, V.V., 2006. Pliotsen I Kvarter Vostochnogo Sklona Yuzhnogo Urala I Zaural'ya [Pliocene and Quaternary of the Eastern Slope of the Urals and Transurals]. Institute of Geology and Geochemistry, Uralian Branch RAS Press, Ekaterinburg, pp. 1-223 (in Russian).

Steklov, A.A., 1966. Nazemnyye Mollyuski Neogena Predkavkaz'ya I Ikhstratigraficheskoye Znacheniye [Neogene Terrestrial Molluscs of the ForeCaucasus and Their Strartigraphical Significance]. Proceedings of the Geological Institute RAS. 163. Nauka Press, Moscow, pp. 1-262 (in Russian).

Stuart, A.J., Lister, A.M., 2014. New radiocarbon evidence on the extirpation of the spotted hyaena (Crocuta crocuta (Erxl.)) in northern Eurasia. Quat. Sci. Rev. 96, 108-116.

Sümegi, P., Krolopp, E., 2002. Quartermalacological analyses for modeling of the upper weichselian palaeoenvironmental changes in the carpathian basin. Quat. Int. 91, 53-63.

Sümegi, P., Gulyás, S., Persaits, G., GergelyPáll, D., Molnar, D., 2011. The loess-paleosol sequence of Basaharc (Hungary) revisited: mollusc-based paleoecological results for the Middle and Upper Pleistocene. Quat. Int. 240, 181-192.

Vakhrushev, G.V., 1960. Zagadki Kapovoy Peshchery (Shulgan) [Riddles of the Kapova Cave (Shulgan)]. Ufa, pp. 1-30 (in Russian).

Veklich, M.F., Sirenko, N.A., 1972. Opornyye Geologicheskiye Razrezy Antropogena Ukrainy [Anthropogene Geological Key Sites of Ukraine. Part 3. Naukova Dumka Press, Kiev, pp. 1-225 (in Russian).

Velivetskaya, T.A., Smirnov, N.G., Kiyashko, S.I., Ignatiev, A.V., Ulitko, A.I., 2016. Resolution-enhanced stable isotope profiles within the complete tooth rows of Late Pleistocene bisons (Middle Urals, Russia) as a record of their individual development and environmental changes. Quat. Int. 400, 212-226.

Volkov, R.B., Shirokov, V.N., Ulitko, A.I., 2007. Izdeliya iz kosti, bivnya i roga s verkhnepaleoliticheskoy stoyanki v Grote Bobylek [Artefacts made of bone, tusk and horns from the Upper Palaeolithic site in the Bobylek Grotto]. Russian Archaeology 4 102-106 (in Russian).

Walker, M., Johnsen, S., Rasmussen, S.O., Steffensen, J.P., Popp, T., Gibbard, P., Hoek, W., Lowe, J., Andrews, J., Björck, S., Cwynar, L.C., Hughen, K., Kershaw, P., Kromer, B., Litt, T., Lowe, D.J., Nakagawa, T., Newnham, R., Schwander, J., 2009. Formal definition and dating of the GSSP (Global Stratotype Section and Point) for the base of the Holocene using the Greenland NGRIP ice core, and selected auxiliary records. J. Quat. Sci. 24, 3-17.

Yakhemovich, N.N., 1965. Antropogenovyye otlozheniya vostochnogo sklona Yuzhnogo Urala [Anthropogene deposits of the eastern slope of the Southern Urals]. In: Anthropogene of the Southern Urals. Nauka Press, Moscow, pp. 114-139 (in Russian).

Yakhemovich, V.L., Nemkova, V.K., Verbitskaya, N.P., Sukhov, V.P., Popov, G.I., 1970. Etapy geologicheskogo razvitiya Bashkirskogo Predural'ya v kaynozoye [Stages of the geological development of the Bashkirian Fore-Urals during Cenozoic]. In: Yakhemovich, V.L. (Ed.), Cenozoic of the Bashkirian Fore-Urals. V. 2. Part 3. Nauka Press, Moscow (in Russian).

Yakovlev, A.G., 2012. Novyye nakhodki melkikh mlekopitayushchikh v kul'turnom sloye peshchery Shul'gan-Tash (Kapovaya) [New finds of small mammals in the cultural layer of the Shulgan-Tash (Kapova) cave]. In: Geology, Minerals and Geo-Ecology
Problems of Bashkortostan, the Urals and Adjacent Territories: Proceedings of the 9th Interregional Conference. Ufa, November 19-22, 2012. DizainPress, Ufa, pp. 67-68 (in Russian).

Yakovlev, A.G., 2014. Pozdneneopleystotsenovaya fauna melkikh mlekopitayushchikh iz mestonakhozhdeniya v peshchere Kul'yurt-Tamak (Yuzhnyy Ural) [Late NeoPleistocene fauna of small mammals located in the Kulurt-Tamak Cave (Southern Ural)]. In: Puchkov, V.N. (Ed.), Geological Collection, 11. Informational Materials. DizainPoligrafServis Press, Ufa, pp. 84-85 (in Russian).

Yakovlev, A.G., Danukalova, G.A., Alimbekova, L.I., Sataev, R.M., Nurmukhametov, I.M., Makarova, O.V., 2000. Biostratigraficheskaya kharakteristika geologicheskogo pamyatnika prirody "Peshchera Nukatskaya“ [Biostratigraphical characteristic of the geological relic "Nukatskaja cave"]. In: Kosintsev, P.A. (Ed.), Pleystotsenovyye I Golotsenovyye Fauny Urala [Pleistocene and Holocene Faunas of Urals]. Publishing House Riphei, Chelyabinsk, pp. 81-104 (in Russian).

Yakovlev, A.G., Danukalova, G.A., Alimbekova, L.I., Kosintsev, P.A., Morozova, E.M., Eremeev, A.A., 2003. Biostratigraficheskaya kharakteristika golotsenovykh otlozheniy mestonakhozhdeniya grot arkheologov (Yuzhnyy Ural) [Biostratigraphic characteristics of Holocene deposits of the Archaeologists Grotto (Southern Urals)]. In: Puchkov, V.N. (Ed.), Geological Collection, 3. Informational Materials. Gilem press, Ufa, pp. 92-98 (in Russian).

Yakovlev, A., Danukalova, G., Osipova, E., 2013. Biostratigraphy of the Upper Pleistocene (Upper Neopleistocene) of the Southern Urals. Quat. Int. 292, 150-167.

Yakovlev, A.G., Danukalova, G.A., Yakovleva, T.I., Alimbekova, L.I., Morozova, E.M., 2004. Biostratigraficheskaya kharakteristika golotsenovykh otlozheniy mestonakhozhdeniya "grot Tashmurun" (yuzhnyy ural) [Biostratigraphic characteristics of Holocene sediments of the "Grotto Tashmurun" locality (Southern Urals)]. In: Puchkov, V.N. (Ed.), Geological Collection, 4. Informational Materials. Ufa. OOO "DisignPoligraphServis", Ufa, pp. 101-105. (in Russian). http://ig.ufaras.ru/ publikatsii/geologicheskie-sborniki/geologicheskiy-sbornik-4-2004-g/.

Yakovlev, A.G., Danukalova, G.A., Alimbekova, L.I., Yakovleva, T.I., Eremeev, A.A. Morozova, E., 2005. Biostratigraficheskaya kharakteristika otlozheniy pozdnego neopleystotsena - golotsena v rayone pamyatnika prirody «Vodopad Atysh» (Yuzhnyy Ural) [Biostratigraphical characteristic of the Upper Neopleistocene Holocene deposits of the natural monument "Atysh waterfall" surroundings (Southern Urals)]. In: Kosintsev, P.A. (Ed.), Fauny Urala i Sibiri v pleystotsene i golotsene [Faunas of Urals and Siberia during Pleistocene and Holocene]. Publishing House Riphei, Chelyabinsk, pp. 260-304 (in Russian).

Yakovlev, A., Danukalova, G., Kosintcev, P., Alimbekova, L., Morozova, E., 2006. Biostratigraphy of the late Palaeolithic site of "Bajslan-tash Cave" (the Southern Urals). Quat. Int. 149 (1), 115-121.

Yakovlev, A.G., Yakovleva, T.I., Bakiev, A.G., Gorelov, R.A., 2013. Presmykayushchiyesya i mlekopitayushchiye iz golotsenovykh mestonakhozhdeniy na Samarskoy Luke. Soobshcheniye 1. Vovanova cave [Reptiles and mammals from Holocene locations on the Samara Luka. Message 1. Vovanova cave]. Izvestiya Samarskogo nauchnogo tsentra Rossiyskoy akademii nauk 15 (3), 164-168 (in Russian).

Yakovlev, A.G., Yakovleva, T.I., Bakiev, A.G., Gorelov, R.A., 2013b. Presmykayushchiyesya i mlekopitayushchiye iz golotsenovykh mestonakhozhdeniy na Samarskoy Luke. Soobshcheniye 2. Peshchera Strel'nenskaya [Reptiles and mammals from Holocene locations on the Samara Luka. Message 2. Strelnenskaya cave]. Izvestiya Samarskogo nauchnogo tsentra Rossiyskoy akademii nauk 15 (3/1), 472-475 (in Russian).

Yakovleva, T.I., Yakovlev, A.G., Bakiev, A.G., Gorelov, R.A., 2014. Zemnovodnyye iz golotsenovykh mestonakhozhdeniy na Samarskoy Luke [Amphibians from Holocene localities on the Samara Luka]. Modern herpetology 14 (1-2), 57-59 (in Russian).

Zagwijn, W.H., 1996. Borders and boundaries: a century of stratigraphical research in the Tegelen-Reuver area of Limburg (The Netherlands). In: Volume of Abstracts of the INQUA-SEQS Conference "The Dawn of the Quaternary", vols. 16-21. pp. 2-9 June 1996.

Zhadin, V.I., 1952. Molluski presnych vod SSSR [Molluscs of Freshwaters of USSR]. (Transactions of the Zoological Institute AC USSR, vol. 46). Academy of Sciences of USSR Press, Moscow, Leningrad, pp. 1-376.

Zhamoida, A.I., Girshgorn, L.C.H., Kovalevsky, O.P., Oleynikov, A.N., Prozorovskaya, E.L., Margulis, L.S., Khramov, A.N., Shkatova, V.K., 2006. Stratigraphicheskyi Kodeks Rossii [Stratigraphic Code of Russia], third ed. VSEGEI Press, Sankt Petersburg, pp. 1-96 (Interdepartmental Stratigraphical Committee) (in Russian).

Zhitenev, V.S., 2009. S.N. Bibikov I Pervobytnaya Arkheologiva [S.N. Bibikov and Prehistoric Archaeology]. IIMK RAN Publishers, St. Petersburg, pp. 219-223 (in Russian).

Zhitenev, V.S., 2018. Kapova Peshchera - Paleoliticheskoye Podzemnoye Svyatilishche [Kapova Cave - Palaeolithic Underground Sanctuary]. Indril Press, Moscow p. 226, (in Russian). 